\title{
Secondary organic aerosol formation in cloud droplets and aqueous particles (aqSOA): a review of laboratory, field and model studies
}

\author{
B. Ervens ${ }^{1,2}$, B. J. Turpin ${ }^{3}$, and R. J. Weber ${ }^{4}$ \\ ${ }^{1}$ CIRES, University of Colorado, Boulder, CO, USA \\ ${ }^{2}$ NOAA, ESRL/CSD Boulder, CO, USA \\ ${ }^{3}$ Department of Environmental Sciences, Rutgers University, New Brunswick, NJ, USA \\ ${ }^{4}$ Georgia Institute of Technology, School of Earth and Atmospheric Sciences, Atlanta, GA, USA
}

Received: 25 July 2011 - Published in Atmos. Chem. Phys. Discuss.: 8 August 2011

Revised: 13 October 2011 - Accepted: 13 October 2011 - Published: 9 November 2011

\begin{abstract}
Progress has been made over the past decade in predicting secondary organic aerosol (SOA) mass in the atmosphere using vapor pressure-driven partitioning, which implies that SOA compounds are formed in the gas phase and then partition to an organic phase (gasSOA). However, discrepancies in predicting organic aerosol oxidation state, size and product (molecular mass) distribution, relative humidity (RH) dependence, color, and vertical profile suggest that additional SOA sources and aging processes may be important. The formation of SOA in cloud and aerosol water (aqSOA) is not considered in these models even though water is an abundant medium for atmospheric chemistry and such chemistry can form dicarboxylic acids and "humic-like substances" (oligomers, high-molecular-weight compounds), i.e. compounds that do not have any gas phase sources but comprise a significant fraction of the total SOA mass. There is direct evidence from field observations and laboratory studies that organic aerosol is formed in cloud and aerosol water, contributing substantial mass to the droplet mode.

This review summarizes the current knowledge on aqueous phase organic reactions and combines evidence that points to a significant role of aqSOA formation in the atmosphere. Model studies are discussed that explore the importance of aqSOA formation and suggestions for model improvements are made based on the comprehensive set of laboratory data presented here. A first comparison is made between aqSOA and gasSOA yields and mass predictions for selected conditions. These simulations suggest that aqSOA might contribute almost as much mass as gasSOA to the SOA budget, with highest contributions from biogenic emissions
\end{abstract}

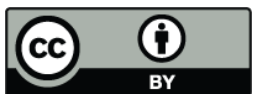

Correspondence to: $\mathrm{B}$. Ervens (barbara.ervens@noaa.gov) of volatile organic compounds (VOC) in the presence of anthropogenic pollutants (i.e. $\mathrm{NO}_{\mathrm{x}}$ ) at high relative humidity and cloudiness. Gaps in the current understanding of aqSOA processes are discussed and further studies (laboratory, field, model) are outlined to complement current data sets.

\section{Introduction}

A role for organic aerosols (OA) in the climate system has been recognized over several decades and much progress has been made in characterizing OA sources, transformations and radiative impacts. Globally, about $20 \%$ of the total OA mass is directly emitted (primary organic aerosols, POA) (Kanakidou et al., 2005; Spracklen et al., 2011). Traditionally, secondary organic aerosol (SOA) formation is thought to occur by gas phase photochemistry followed by absorption of semi-volatile products into preexisting OA mass ("gasSOA", Fig. 1) (Pankow, 1994a, b; Odum et al., 1996). Recently, it has been recognized that a substantial fraction (50$75 \%$, Shrivastava et al., 2006) of POA is semivolatile, evaporates when the plume becomes more dilute, and is then available in the gas phase to take part in photochemical reactions (Fig. 1) (Robinson et al., 2007). This material is like SOA in some ways and like POA in others; its atmospheric concentrations can be reduced with primary PM controls, but it has the physicochemical properties of SOA. Whereas previous models tended to underestimate SOA mass (e.g. DeGouw et al., 2005; Heald et al., 2006; Volkamer et al., 2006; Jimenez et al., 2009), the treatment of POA as semivolatile improved OA mass prediction (e.g. Hodzic et al., 2010; Lee-Taylor et al., 2011), but the temporal variability (e.g. Murphy and Pandis, 2009; Jathar et al., 2011) and vertical profile of OA

Published by Copernicus Publications on behalf of the European Geosciences Union. 
remained poorly captured (Carlton et al., 2008; Heald et al., 2011). While currently it is thought that these semivolatile compounds add to SOA mass by further oxidation in the gas phase and re-condensation into particulate organic matter, it is at least as likely that this oxidized material, as well as other water-soluble products of gas-phase photochemistry, dissolve into an aqueous phase where it forms SOA through further oxidation (aqSOA, Fig. 1).

More than a decade ago, it was hypothesized that organic compounds are oxidized in the aqueous phase of cloud and fog droplets and products remain in the particle phase upon water evaporation (Blando and Turpin, 2000). More recently, it was hypothesized that chemical processes in the aqueous phase of hygroscopic particles (aerosol water) can also efficiently contribute to aqSOA mass (Volkamer et al., 2007). Aqueous phase processes start with water-soluble, polar precursors and form SOA that is more oxygenated than gasSOA as they lead to functionalization or accretion (e.g. acid formation, oligomerization) rather than to breakage of the carbon structure as in gas phase reactions. Laboratory studies have shown that at low, cloud-relevant aqueous phase concentrations, organic acids (e.g. oxalate) are formed from small aldehydes and related compounds. At the higher solute concentrations associated with aerosol water, "high-molecularweight compounds" (HMWC) tend to preferentially form (Lim et al., 2010). As discussed below, the organic fractions of atmospheric aerosol particles have properties consistent with such aqueous laboratory studies.

While for gasSOA, the amount of preexisting organic mass determines the extent to which condensable species are added to particles ("partitioning theory", Odum et al., 1996), aqSOA formation depends on the amount of cloud, fog or aerosol water. Globally, aerosol water exceeds dry aerosol mass (ammonium, sulfate, nitrate) by a factor of 2-3 (Meng et al., 1995; Wang et al., 2008); thus, the accessibility of semivolatile (or low volatility), water-soluble species to an aqueous phase might be greater than to an organic phase. Freshly emitted, hydrophobic particles are converted into hygroscopic, water-containing particles within several hours ( 10's km) (Ervens et al., 2010; Riemer et al., 2010); thus, regions with only hydrophobic particles with very little aerosol water are very limited.

AqSOA formation will not only affect the total SOA mass predictions but also impacts aerosol properties that translate into the aerosol direct and indirect effects in more ways than just increased aerosol mass burden. Condensation of low volatility species (gasSOA) and volume phase reactions (aqSOA) modify aerosol size distributions in different ways, the former adding mass to the condensation mode and, the latter adding mass to the droplet mode (John et al., 1990). Highresolution analytical techniques capable of molecular characterization of OA mass suggest that a substantial fraction of SOA is composed of material that is more highly oxidized (higher oxygen-to-carbon $(\mathrm{O} / \mathrm{C})$ ratio) than gasSOA formed in dry smog chamber experiments (Aiken et al., 2008; Ng et

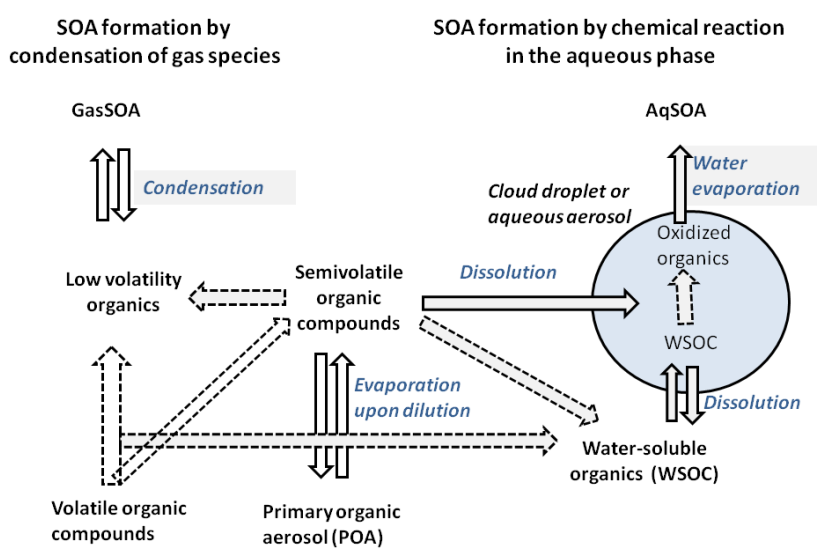

Fig. 1. Schematic of gasSOA and aqSOA formation pathways in the gas and aqueous phases of the atmosphere. Dashed arrows denote oxidation reactions.

al., 2010), whose yields are the basis for predicting SOA in models. Models that include the prediction of O/C ratios often underestimate the degree of oxygenation of SOA which points to a biased prediction of the product distribution and related SOA properties (e.g. Jathar et al., 2011). SOA formation through aqueous chemistry could explain the high $\mathrm{O} / \mathrm{C}$ ratios as observed in atmospheric organic aerosol. The O/C ratio can be related to SOA hygroscopicity which affects interaction with water-vapor, influencing haze and cloud drop formation, and the scattering/absorbing of radiation. There is some evidence that aqSOA can comprise light absorbing organics (e.g. Gelencser et al., 2003; Shapiro et al., 2009). The addition of different types of organics (water-soluble aqSOA, as opposed to more hydrophobic gasSOA) also might lead to phase separation within a single particle (Bertram et al., 2011). Because aqSOA is more oxygenated and watersoluble, we also expect its atmospheric lifetime to be shorter than gasSOA as it is more readily removed by wet deposition (Fu et al., 2008, 2009).

A host of organic acids has been observed in ambient particles, with oxalate globally ubiquitous throughout the tropospheric column (e.g. Kawamura and Sakaguchi, 1999; Kawamura et al., 2003). The atmospheric dynamics of oxalate suggests that it is predominantly secondary, and yet its abundance has not been explained by gas phase chemistry. Large multifunctional organic compounds including oligomeric SOA constituents and organics that include heteroatoms (e.g. sulfur, nitrogen; Blando et al., 1998; Romero and Oehme, 2005; Surratt et al., 2007a; Stone et al., 2009) comprise the largest component of OA (Fuzzi et al., 2001). Due to their structural similarities with humic substances, these compounds are often called "humic-like substances (HULIS)". However, it has been noted that their similarities to humic compounds are limited (Graber and Rudich, 2006) and thus in the present review these compounds are rather 
termed HMWC. Substantial amounts of HMWC have been observed to form in biomass burning plumes (Miyazaki et al., 2009b), rural areas (Lin et al., 2010b) and urban environments (Krivacsy et al., 2008). While it seems possible that HMWC might be also formed in an organic phase of particles, the high polarity and water-solubility of this material rather suggests their formation in an aqueous phase (Fuzzi et al., 2001). Based on their atmospheric dynamics these compounds are believed to be predominantly secondary and not directly emitted, but their formation processes are not captured by gasSOA models. Their observation in a wide variety of environments suggests the ubiquitous occurrence of aqueous phase processing.

In this review, we document the substantial evidence that aqueous phase chemistry as observed in laboratory studies (Sect. 2) is important in the atmosphere. Evidence of aqSOA from field studies together with model predictions is discussed (Sect. 3). For selected precursors and conditions, predicted aqSOA and gasSOA yields and masses are compared (Sect. 4). Finally, major uncertainties in determining aqSOA formation are assessed which should be considered in future studies (Sect. 5).

\section{Laboratory experiments of aqSOA formation}

\subsection{Photochemical aqueous phase reactions}

\subsubsection{Carbonyl compounds $\left(\leq \mathbf{C}_{5}\right)$}

The $\mathrm{OH}$ radical represents the main oxidant of organic compounds in the aqueous phase of cloud droplets (Ervens et al., 2003a). Kinetic data for aqueous phase reactions with $\mathrm{OH}$ are available or can be estimated based on structurereactivity-relationships (e.g. Ervens et al., 2003b; Herrmann, 2003; Monod et al., 2005; Monod and Doussin, 2008; Minakata et al., 2009; Herrmann et al., 2010). Most OH reactions with organic compounds are near the diffusion limit in the aqueous phase $\left(k=10^{9}-10^{10} \mathrm{M}^{-1} \mathrm{~s}^{-1}\right)$. OH concentrations of $\sim 10^{-13} \mathrm{M}$ and $10^{-12} \mathrm{M}$ in cloud and aerosol water, respectively, have been estimated based on model studies (Ervens et al., 2003a; Ervens and Volkamer, 2010) since there are no measurements in ambient aerosol and/or cloud water available. Thus, a first-order rate constant $(k[\mathrm{OH}])$ of $<\sim 10^{-3} \mathrm{~s}^{-1}$ in cloud water and $<\sim 10^{-2} \mathrm{~s}^{-1}$ in aerosol water can be estimated for converting water-soluble compounds into aqSOA mass. This estimate is based on the assumption of identical transport parameters into, on and inside of cloud droplets and aqueous particles.

$\mathrm{C}_{2}$ and $\mathrm{C}_{3}$ carbonyl compounds (e.g. glyoxal, glycolaldehdyde, glyoxylic acid, glycolic acid, methylglyoxal, pyruvic acid) represent first- and/or second-generation gasphase oxidation products of both anthropogenic (e.g. aromatics, acetylene) and biogenic (isoprene) compounds. First generation products of isoprene include methacrolein
(MACR) and methylvinyl ketone (MVK), which are less soluble but formed with higher yields. Henry's law constants $\left(K_{\mathrm{H}}\right)$ for the $\mathrm{C}_{2}-\mathrm{C}_{3}$ carbonyl compounds are in the range of $10^{3}-10^{5} \mathrm{M} \mathrm{atm}^{-1}$; those for MVK and MACR are much smaller in neutral or moderately acidic solution $\left(K_{\mathrm{H}}(\mathrm{MVK})=41 \mathrm{M} \mathrm{atm}^{-1}, K_{\mathrm{H}}(\mathrm{MACR})=6.5 \mathrm{M} \mathrm{atm}^{-1}\right.$, Iraci et al., 1999), which suggests that only a small fraction of these compounds are present in the aqueous phase of particles.

The chemistry of carbonyl compounds in the aqueous phase differs from that in the gas phase in part because these compounds hydrate. Aqueous-phase product formation also depends on the concentrations of organics in solution. Glyoxal has been used as a model compound to explore these differences. The aqueous $\mathrm{OH}$-radical oxidation of glyoxal upon hydration has been discussed in recent detailed studies (Tan et al., 2009; Ervens and Volkamer, 2010; Lim et al., 2010). In brief, in dilute solutions with [Glyoxal $]_{\mathrm{aq}}<1 \mathrm{mM}$ (resembling solute concentrations as in cloud water, e.g. Igawa et al., 1989; Munger et al., 1995), the oxidation of glyoxal by the $\mathrm{OH}$ radical yields glyoxylic acid, which is further oxidized to glyoxylic acid (Karpel Vel Leitner and Doré, 1997) (Table 1). Carlton et al. (2007) first observed HMWC in glyoxal photooxidation experiments at organic concentrations that were higher than in cloud water but likely less than in aerosol water ([Glyoxal $]_{\mathrm{aq}} \leq \mathrm{mM}$ ) (Tan et al., 2009). For methylglyoxal and its direct oxidation product, pyruvic acid, a qualitatively similar product pattern has been found at organic cloud-water concentrations with the formation of small acids (oxalic, glyoxylic, acetic) (Tan et al., 2010). At higher concentrations (mM), the same transition to HMWC formation is seen from both pyruvic acid and methylglyoxal (Altieri et al., 2008; Perri et al., 2009) with oligomeric series with fragment patterns that differ by $\Delta M=72\left(\mathrm{C}_{3} \mathrm{H}_{4} \mathrm{O}_{2}\right)$ (Tan et al., 2010, 2011).

Aqueous phase oxidation experiments of isoprene, MACR and MVK in the presence of $\mathrm{OH}$ show very similar product patterns. An explicit mechanism suggests that the oxidation of these $\mathrm{C}_{5}$ carbonyl compounds is closely intertwined with the smaller, more soluble ones that can account for a large fraction of the aqSOA observed in laboratory studies; HMWC are assumed to be intermediates in this reaction scheme (Zhang et al., 2010; D. Huang et al., 2011; Liu et al., 2011). In ambient aerosol particles and cloud droplets, the observed bulk processes will have only a minor importance due to the limited solubility of these aqSOA precursors; however, in the same study it was discussed that surface reactions could occur and contribute more to organic processing and aqSOA formation. Aqueous oxidation experiments with MACR and MVK show that small acids comprise up to $8.8 \%$ and $23.8 \%$, respectively, of the aqSOA yield (defined as mass concentration of aerosol after $7 \mathrm{~h}$, related to the initial aqueous phase MACR and MVK concentrations, Zhang et al., 2010). The value for MACR is in good agreement with experiments over longer time scales that reported aqSOA 
Table 1. Summary of experimental conditions, kinetic data and products from photochemical laboratory experiments leading to aqSOA.

\begin{tabular}{|c|c|c|c|c|c|c|}
\hline & $\begin{array}{l}\text { Organic } \\
\text { reactant } \\
\text { concentration }\end{array}$ & $\begin{array}{l}\text { Oxidant } \\
\text { (Source) }\end{array}$ & $\begin{array}{l}\text { Inorganic } \\
\text { solutes }\end{array}$ & Rate constant & Products & Reference \\
\hline \multirow[t]{6}{*}{ Glyoxal } & $1 \mathrm{mM}$ & $\begin{array}{l}\mathrm{OH} \text { (Pulse } \\
\text { radiolysis) }\end{array}$ & - & $1.1 \times 10^{9} \mathrm{M}^{-1} \mathrm{~s}^{-1 *}$ & - & Buxton et al. (1997) \\
\hline & $0.5 \mathrm{mM}$ & $\begin{array}{l}\mathrm{OH} \\
(0.5 \mathrm{mM} \\
\left.\mathrm{H}_{2} \mathrm{O}_{2}\right)\end{array}$ & - & & $\begin{array}{l}\text { Formic, acetic, glyoxylic, } \\
\text { acetic acid }\end{array}$ & $\begin{array}{l}\text { Karpel Vel Leitner and } \\
\text { Doré (1997) }\end{array}$ \\
\hline & $2 \mathrm{mM}$ & $\begin{array}{l}\mathrm{OH} \\
\left(10 \mathrm{mM} \mathrm{H}_{2} \mathrm{O}_{2}\right)\end{array}$ & - & & $\begin{array}{l}\text { Glyoxylic, oxalic acids } \\
\text { Oligomers }\end{array}$ & Carlton et al. (2007) \\
\hline & $\begin{array}{l}0.03 \mathrm{mM} \\
0.3 \mathrm{mM} \\
3 \mathrm{mM}\end{array}$ & $\mathrm{OH}$ & - & $1.1 \times 10^{8} \mathrm{M}^{-1} \mathrm{~s}^{-1}$ & $\begin{array}{l}\text { - Succinic, oxalic malonic, } \\
\text { malic, tartaric, mesoxalic } \\
\text { acid } \\
\text { - Transition from } \\
\text { "mainly acids" to "mainly } \\
\text { oligomers" } \\
\text { - Oligomers } \\
\left(\Delta=\mathrm{C}_{2} \mathrm{H}_{2} \mathrm{O}_{3}\right)\end{array}$ & $\begin{array}{l}\text { Tan et al. (2009); } \\
\text { Lim et al. (2010) }\end{array}$ \\
\hline & $\sim 0.1-1 \mathrm{M}$ & $\begin{array}{l}\mathrm{OH} \\
(\sim 20 \mathrm{ppm} \\
\left.\mathrm{C}_{2} \mathrm{H}_{2 \mathrm{~g}}\right)\end{array}$ & $\begin{array}{l}\sim 6 \mathrm{M} \\
\left(\mathrm{NH}_{4}\right)_{2} \mathrm{SO}_{4}\end{array}$ & $\begin{array}{l}0.8 \mathrm{~s}^{-1}<k<7 \\
\mathrm{~s}^{-1 *}\end{array}$ & $\begin{array}{l}\text { Fitted } k \text { in order to ex- } \\
\text { plain observed SOA mass } \\
\text { in excess to } \mathrm{OH} \text { reaction; } k \\
\text { scales with } \mathrm{OH} \text { concentra- } \\
\text { tion with highest value at } \\
{[\mathrm{OH}]=10^{7} \mathrm{~cm}^{-3}}\end{array}$ & $\begin{array}{l}\text { Volkamer et al. (2009); } \\
\text { Ervens and Volkamer } \\
\text { (2010) }\end{array}$ \\
\hline & $\sim 0.1-1 \mathrm{M}$ & UV & $\begin{array}{l}\sim 6 \mathrm{M} \\
\left(\mathrm{NH}_{4}\right)_{2} \mathrm{SO}_{4}^{*)}\end{array}$ & & $\begin{array}{l}\text { Glycolic acid sulfate, C-N } \\
\text { compounds }\end{array}$ & Galloway et al. (2009) \\
\hline \multirow[t]{2}{*}{ Glycolaldehyde } & $1 \mathrm{mM}$ & $\begin{array}{l}\mathrm{OH} \\
\left(5 \mathrm{mM} \mathrm{H}_{2} \mathrm{O}_{2}\right)\end{array}$ & - & & $\begin{array}{l}\text { Succinic, malonic, oxalic, } \\
\text { glycolic, glyoxylic acids }\end{array}$ & Perri et al. (2009) \\
\hline & $1 \mathrm{mM}$ & $\begin{array}{l}\mathrm{OH} \\
\left(5 \mathrm{mM} \mathrm{H}_{2} \mathrm{O}_{2}\right)\end{array}$ & $1 \mathrm{mM} \mathrm{H}_{2} \mathrm{SO}_{4}$ & & Organosulfates (esters) & Perri et al. (2010) \\
\hline \multirow[t]{3}{*}{ Methylglyoxal } & $0.1-4 \mathrm{mM}$ & $\begin{array}{l}\mathrm{OH}(\sim 0.3 \mu \mathrm{M}) \\
(0.5 \mathrm{mM} \\
\left.\mathrm{H}_{2} \mathrm{O}_{2}\right)\end{array}$ & - & $7 \times 10^{8} \mathrm{M}^{-1} \mathrm{~s}^{-1 *}$ & - & Ervens et al. (2003b) \\
\hline & $2 \mathrm{mM}$ & $\begin{array}{l}\mathrm{OH} \\
\left(10 \mathrm{mM} \mathrm{H}_{2} \mathrm{O}_{2}\right)\end{array}$ & - & & $\begin{array}{l}\text { Glyoxylic, pyruvic, oxalic, } \\
\text { acids and oligomers with } \\
\mathrm{C}_{3} \mathrm{H}_{4} \mathrm{O}_{2} \text { subunits }\end{array}$ & $\begin{array}{l}\text { Altieri et al. (2008); } \\
\text { Tan et al. (2010) }\end{array}$ \\
\hline & & & & $k=4 \mathrm{~s}^{-1 * * *}$ & $\begin{array}{l}\text { Fitted } k \text { based on observed } \\
\text { aqSOA formation in labo- } \\
\text { ratory studies (Tan et al., } \\
\text { 2010); }\end{array}$ & $\begin{array}{l}\text { This study } \\
\text { For fitting, cf procedure } \\
\text { described for glyoxal } \\
\text { by Ervens and Volka- } \\
\text { mer (2010) }\end{array}$ \\
\hline \multirow[t]{5}{*}{ Pyruvic acid } & $1-12 \mathrm{mM}$ & $\begin{array}{l}\mathrm{OH}(\sim 0.3 \mu \mathrm{M}) \\
(0.5 \mathrm{mM} \\
\left.\mathrm{H}_{2} \mathrm{O}_{2}\right)\end{array}$ & - & & - & Ervens et al. (2003b) \\
\hline & $10 \mathrm{mM}$ & $\begin{array}{l}\mathrm{OH} \\
\left(20 \mathrm{mM} \mathrm{H}_{2} \mathrm{O}_{2}\right)\end{array}$ & - & & $\begin{array}{l}\text { Glyoxylic, oxalic, acids and } \\
\text { oligomers with } \mathrm{C}_{3} \mathrm{H}_{4} \mathrm{O}_{2} \\
\text { subunits }\end{array}$ & Altieri et al. (2006) \\
\hline & $\begin{array}{l}5 \mathrm{mM} \\
10 \mathrm{mM}\end{array}$ & $\begin{array}{l}\mathrm{OH} \\
(20-100 \mathrm{mM} \\
\left.\mathrm{H}_{2} \mathrm{O}_{2}\right)\end{array}$ & - & & Glyoxylic, acetic acid & Carlton et al. (2006) \\
\hline & $100 \mathrm{mM}$ & UV & - & & $\mathrm{C}_{6}, \mathrm{C}_{7}$ carboxylic acids & Guzman et al. (2006) \\
\hline & $\begin{array}{l}5 \mathrm{mM}, \\
10 \mathrm{mM}\end{array}$ & $\begin{array}{l}\mathrm{OH} \\
(100 \mathrm{mM}, \\
\left.20 \mathrm{mM} \mathrm{H}_{2} \mathrm{O}_{2}\right)\end{array}$ & - & & Glyoxylic, acetic acid & Carlton et al. (2006) \\
\hline
\end{tabular}


Table 1. Continued.

\begin{tabular}{|c|c|c|c|c|c|c|}
\hline & $\begin{array}{l}\text { Organic } \\
\text { reactant } \\
\text { concentration }\end{array}$ & $\begin{array}{l}\text { Oxidant } \\
\text { (Source) }\end{array}$ & $\begin{array}{l}\text { Inorganic } \\
\text { solutes }\end{array}$ & Rate constant & Products & Reference \\
\hline \multirow{2}{*}{$\begin{array}{l}\text { Pyruvic }+ \\
\text { Oxalic acid }\end{array}$} & $100 \mathrm{mM}$ & UV & - & & $\mathrm{C}_{6}, \mathrm{C}_{7}$ carboxylic acids & Guzman et al. (2006) \\
\hline & $5 \mathrm{mM}$ each & $\begin{array}{l}\mathrm{O}_{3} \\
\text { (UV light) }\end{array}$ & - & & $\begin{array}{l}\text { Pyruvic acid dimer and } \\
\text { Pyruvic/formic acid-dimer } \\
\text { formation over } \sim 5 \mathrm{~h} \\
\text { (photosensitized) }\end{array}$ & Grgic et al. (2010) \\
\hline \multirow[t]{2}{*}{ MACR } & $\begin{array}{l}0.05 \mathrm{mM} \\
2-5 \mathrm{mM}\end{array}$ & $\begin{array}{l}\mathrm{OH} \\
\left(8 \mathrm{mM} \mathrm{H}_{2} \mathrm{O}_{2}\right) \\
\mathrm{OH} \\
(0.4 \mathrm{mM} \\
\left.\mathrm{H}_{2} \mathrm{O}_{2}\right)\end{array}$ & - & $5.8 \times 10^{9} \mathrm{M}^{-1} \mathrm{~s}^{-1}$ & $\begin{array}{l}\text { methylglyoxal, formalde- } \\
\text { hyde, hydroxyacetone and } \\
\text { acetic acid/acetate } \\
\text { Pyruvic, glyoxylic acid } \\
\text { Oligomer series with } \\
\text { hydroxyl carbonyl and } \\
\text { carboxylic acids }\end{array}$ & $\begin{array}{l}\text { Liu et al. (2009); } \\
\text { El Haddad et al. (2009) }\end{array}$ \\
\hline & $\begin{array}{l}100- \\
500 \mathrm{mM}\end{array}$ & $\begin{array}{l}\mathrm{SO}_{4}^{-} \\
(\mathrm{UV})\end{array}$ & $\begin{array}{l}3.7 \mathrm{M} \\
\left(\mathrm{NH}_{4}\right)_{2} \mathrm{SO}_{4} \text { or } \\
1 \mathrm{M} \mathrm{Na}_{2} \mathrm{SO}_{4}\end{array}$ & $\begin{array}{l}\geq 10^{-5} \mathrm{~s}^{-1} \\
2.5 \times 10^{9} \mathrm{M}^{-1} \mathrm{~s}^{-1}\end{array}$ & $\begin{array}{l}\text { Organosulfates } 150<\mathrm{M} \\
{\left[\mathrm{g} \mathrm{mol}^{-1}\right]<300}\end{array}$ & Noziere et al. (2010b) \\
\hline MVK & $0.2 \mathrm{mM}$ & $\begin{array}{l}\mathrm{OH} \\
\left(2 \mathrm{mM} \mathrm{H}_{2} \mathrm{O}_{2}\right)\end{array}$ & - & $8 \times 10^{8} \mathrm{M}^{-1} \mathrm{~s}^{-1}$ & $\begin{array}{l}\text { Glyoxal, Methylglyoxal, } \\
\text { Pyruvic, Acetic, Oxalic, } \\
\text { malonic acids, HMWC }\end{array}$ & Zhang et al. (2010) \\
\hline Isoprene & $11 \mathrm{mM}$ & $\mathrm{SO}_{4}^{-}$ & & & Organosulfates & Noziere et al. (2010b) \\
\hline$\alpha$-pinene & $150 \mathrm{mM}$ & $\mathrm{SO}_{4}^{-}$ & & & Organosulfates & Noziere et al. (2010b) \\
\hline $\begin{array}{l}\text { 3,5-dihydroxy } \\
\text { benzoic acid }\end{array}$ & $\begin{array}{l}0.02 \mathrm{mM} \\
2 \mathrm{mM}\end{array}$ & $\begin{array}{l}\mathrm{OH} \\
(0.1 \mathrm{mM} \\
\mathrm{H}_{2} \mathrm{O}_{2+} \\
0.05 \mathrm{mM} \\
\left.\mathrm{FeCl}_{3}\right)\end{array}$ & - & & $\begin{array}{l}\text { Light absorbing dimer } \\
\text { (phenoxy radical) }\end{array}$ & $\begin{array}{l}\text { Gelencser et al. (2003); } \\
\text { Hoffer et al. (2004) }\end{array}$ \\
\hline $\begin{array}{l}\text { Phenol } \\
\text { Guaiacol } \\
\text { Syringol }\end{array}$ & $0.1 \mathrm{mM}$ & $\begin{array}{l}\mathrm{OH} \\
(0.1 \mathrm{mM} \\
\left.\mathrm{H}_{2} \mathrm{O}_{2}\right)\end{array}$ & - & & $\begin{array}{l}\text { Small organic acids, } \\
\text { phenolic dimers and higher } \\
\text { oligomers formed from } \\
\text { phenoxy radicals }\end{array}$ & Sun et al. (2010) \\
\hline $\begin{array}{l}\text { Phenols, } \\
\text { Vanillyls, } \\
\text { Syringols }\end{array}$ & $10 \mathrm{mM}$ & $\begin{array}{l}\mathrm{OH} \\
\left(1 \mathrm{mM} \mathrm{H}_{2} \mathrm{O}_{2}\right)\end{array}$ & - & - & $\begin{array}{l}\text { Absorbing products } \\
(1 \sim 500 \mathrm{~nm}) \text { Spectra struc- } \\
\text { ture depending on organic }\end{array}$ & $\begin{array}{l}\text { Chang and Thompson } \\
\text { (2010) }\end{array}$ \\
\hline
\end{tabular}

* These rate constants are used in the box model studies in Sect. 4.;

** in the model simulations it was assumed that this rate constant also scales with the gas phase OH concentration as it had been inferred for the corresponding glyoxal reaction (Ervens and Volkamer et al., 2010).

yields of 2-12\% with highest values after $22 \mathrm{~h}$ (El Haddad et al., 2009).

The direct aqueous phase reaction of MVK and MACR with ozone is probably not a competitive pathway as compared to the much faster $\mathrm{OH}$-initiated reactions, but it might act as an important source of oxidants (e.g. $\mathrm{H}_{2} \mathrm{O}_{2}$ ) (Chen et al., 2008). While $\mathrm{H}_{2} \mathrm{O}_{2}$ itself reacts only slowly with organic carbonyl compounds (Stefan and Bolton, 1999), it might be a precursor for $\mathrm{OH}$ (either by photolysis, or by Fenton reaction with $\mathrm{Fe}^{2+}$ or $\mathrm{Cu}^{+}$) and thus could provide an additional radical source in the aqueous phase that could start $\mathrm{OH}$-initiated processes.
It has been shown that SOA formation rates in laboratory aerosol experiments are 2-3 orders of magnitude faster than those that were predicted based on the $\mathrm{OH}$ reaction using uptake and reaction parameters as for dilute aqueous solutions (Ervens and Volkamer, 2010) which suggests that the overall aqSOA production rate (per volume of water) is higher in aerosol than in cloud water. However, this rapid photochemical conversion crucially depends on the nature of the present seed aerosol and the "history" of the reaction chamber that might exhibit background organic residues (Volkamer et al., 2009; Galloway et al., 2011b). While this difference in glyoxal reactivity cannot be solely ascribed to faster kinetics due 
to ionic strength effects (Herrmann, 2003), it is rather possible that additional radical pathways in aqueous particles occur that are largely suppressed in dilute aqueous phase, but lead to accretion products of organic radicals at higher organic concentrations. Since observed aqSOA formation both scales with bulk aerosol water mass and particle surface, this additional pathway has been parameterized by either a bulk aqueous phase process or a surface-limited process (Ervens and Volkamer, 2010). Data from bulk aqueous phase experiments have been fitted to develop detailed reaction mechanisms for the possible formation and recombination of organic radicals of both glyoxal and methylglyoxal (Lim et al., 2010; Tan et al., 2010) (Table 1).

Experiments in the absence of $\mathrm{OH}$, but under UV light, show similar products from pyruvic acid suggesting that intermediate organic radicals can be also formed by direct photolysis (Guzman et al., 2006). Products in that study included $\mathrm{C}_{6}$ and $\mathrm{C}_{7}$ carboxylic acids which could act as precursors for smaller acids. Solutions of both oxalic and pyruvic acid also showed the formation of HMWC with oligomeric structures in the presence of ozone and UV light (Grgic et al., 2010). In those experiments, it was suggested that pyruvic acid acts as a photosensitizer that accelerates the oxidation of oxalic acid leading to oligomer formation, i.e. indicating an additional role of carbonyl compounds in (or on) the aqueous phase that is not captured by current kinetic models.

All aforementioned experiments were performed in pure water and the only difference between "cloud-water" and "aerosol-water" experiments was the organic aqSOA precursor concentration. However, in atmospheric aerosol water the concentrations of inorganic solutes (e.g. ammonium, sulfate) are much higher and thus aqueous ammonium sulfate solutions might better represent the reaction medium for wet aerosols. Photooxidation of glyoxal, methylglyoxal, glycolaldehyde, methacrolein, $\alpha$-pinene, and isoprene in an aqueous sulfate solution yields organosulfate species. It is proposed that these species are produced in reactions involving sulfate radicals $\left(\mathrm{SO}_{4}^{-}\right)$formed in the presence of $\mathrm{OH}$ (Noziere et al., 2010b; Perri et al., 2010).

$\mathrm{HSO}_{4}^{-}+\mathrm{OH} \rightarrow \mathrm{SO}_{4}^{-}+\mathrm{H}_{2} \mathrm{O}$

The rate constant of this reaction $\left(k=3.5 \times 10^{5} \mathrm{M}^{-1} \mathrm{~s}^{-1}\right.$, Tang et al., 1988) increases with decreasing $\mathrm{pH}$, which might explain trends of increased organosulfate yields under more acidic conditions in ambient aerosol particles (Edney et al., 2005; Surratt et al., 2007b; H. Zhang et al., 2011). The molecular weight distribution observed in these laboratory experiments suggests that not only the sulfates of the organic parent compounds but also HMWC with sulfate groups are formed (Noziere et al., 2010b). Experiments in ammonium sulfate solutions in the absence of $\mathrm{OH}$ sources but under UV illumination also lead to organosulfates, suggesting additional sources of the sulfate radical (Galloway et al., 2009).

The ozonolysis of limonene results in gasSOA formation. Products comprise water-soluble oligomers that can be dis- solved in the aerosol aqueous phase where they are further oxidized (Bateman et al., 2011). These experiments demonstrate that the aqueous phase can change the fate and properties of compounds typically considered to be gasSOA products by acting as a SOA sink whereas in organic particles the further oxidation is likely hindered due to diffusion limitations of reactants.

\subsubsection{Aromatic compounds}

Monocyclic aromatic compounds can be considered as proxies for anthropogenic (e.g. benzene, toluene, xylene) and biomass burning emissions (e.g. lignin). Compounds such as benzene, toluene, and xylene react in the gas phase and form gasSOA with highest yields at low $\mathrm{NO}_{\mathrm{x}}$ conditions $(\mathrm{Ng}$ et al., 2007). At high $\mathrm{NO}_{\mathrm{x}}$ levels, the formation of carbonyl products (glyoxal, methylglyoxal) is favored which suggests different sensitivities of gasSOA and aqSOA towards $\mathrm{NO}_{\mathrm{x}}$. As described above, these compounds are precursors of aqSOA but not gasSOA. Photochemical aqueous phase experiments suggest that ring-retaining aromatic oxidation products from phenol and its methoxylated derivates guaiacol and syringol might contribute to aqSOA as they form aromatic dimer products in high yields (near unity, related to the initial aqueous phase concentration) by recombination of phenoxy radicals (Sun et al., 2010). The total aromatic concentrations in these studies $(100 \mu \mathrm{M})$ resemble those as found from wood smoke markers in winter fog (Sagebiel and Seiber, 1993); however, at other locations much smaller phenol concentrations are generally observed (Anastasio et al., 1997).

Similar results as for methoxyphenols were found in laboratory experiments with other phenolic, vanillyl and syringyl compounds (Chang and Thompson, 2010) and 3,5-dihydroxy benzoic acid (Gelencser et al., 2003). For these latter compounds aqueous reaction times of more than one day were needed to detect pronounced signals of ring-opening products (Hoffer et al., 2004). Although ring-cleavage products of aromatics will follow reactions as discussed in Sect. 2.1.1, ring-retaining products will add more mass on a mass-tomass basis and could also affect the optical properties of SOA due to their structural similarities to soot (Sect. 2.4.2).

It should be noted that the atmospheric reaction time scales will depend on the availability of organics and reactants (oxidants) in aerosol and cloud water; as the quantitation of $\mathrm{OH}$ radicals in the aqueous laboratory experiments is usually not performed, the comparison of reaction rates from different experiments might not be meaningful. A more useful comparison of the importance of different pathways can only be obtained by using multiphase process models that predict aqSOA formation using the rate constants as summarized in Tables 1 and 2 . 


\subsection{Dark reactions of carbonyl compounds}

While photochemical (oxidative) reactions are irreversible, several thermal (dark) reactions form products reversibly, i.e. their reactions can be expressed as equilibria, in form of effective Henry's law constants $K_{\mathrm{H}} *$ (Kroll et al., 2005b; Galloway et al., 2009; Ip et al., 2009). These constants are often higher by several orders of magnitude than the physical solubility $\left(K_{\mathrm{H}}\right)$ and effective Henry's law constants that include hydration $\left(K_{\mathrm{H}, \mathrm{Hydr}}\right)$. The observed gas/particle partitioning, $K_{\mathrm{H}}{ }^{*}$, of glyoxal has been interpreted as a product of $K_{\mathrm{H}, \mathrm{Hydr}}$ and the equilibrium constant for oligomerization $K_{\text {olig }}$ (Ervens and Volkamer, 2010).

$K_{\mathrm{H}}^{*}=K_{\mathrm{H}, \mathrm{Hydr}}\left(1+K_{\text {olig }}\right)$

$K_{\text {olig }}$, and thus, $K_{\mathrm{H}}{ }^{*}$, are only valid for reversible (dark) oligomerization and not for irreversible photochemical reactions (Ervens and Volkamer, 2010; Lim et al., 2010). A more recent study discusses that the enhanced uptake of glyoxal is not due to oligomerization but due to a shift of the partitioning of the glyoxal dihydrate towards the particle phase which is more stabilized in ionic solutions (Yu et al., 2011). The hydration and oligomerization of glyoxal, methylglyoxal and other carbonyl compounds are thermodynamically favorable (Barsanti and Pankow, 2004, 2005; Kua et al., 2008; Krizner et al., 2009) but their kinetic formation is slow with rate constants of $k_{\text {hydration }}<0.01 \mathrm{~s}^{-1}$ (Creighton et al., 1988; Krizner et al., 2009) and $k_{\text {olig }}=100 \mathrm{M}^{-1} \mathrm{~s}^{-1}$ (glyoxal), respectively (Ervens and Volkamer, 2010). Overall, these products contribute little mass to the total predicted aqSOA budget since (i) their formation rate constants are small, (ii) the largest observed molecules only contain 3-4 glyoxal subunits and thus are substantially smaller than oligomers from photochemical reactions and (iii) they are formed reversibly and thus their major fraction will evaporate together with water. However, glyoxal oligomerization has recently been shown to contribute significantly to nanoparticle growth (L. Wang et al., 2010, 2011).

Methylglyoxal and other carbonyl compounds that form enol structures can undergo aldol condensation reactions. While aldol condensation products (e.g. from methylglyoxal) are thermodynamically favorable (Barsanti and Pankow, 2005), both experimental and theoretical studies have shown that rate constants of aldol condensation are too low to be important for significant aqSOA formation under typical atmospheric conditions $\left(0.074 \mathrm{M}^{-1} \mathrm{~s}^{-1}<k_{\text {aldol }}<15 \mathrm{M}^{-1} \mathrm{~s}^{-1}\right.$ (Casale et al., 2007; Minerath and Elrod, 2009); $k_{\text {aldol }}<$ $3 \mathrm{M}^{-1} \mathrm{~s}^{-1}$, Noziere et al., 2006).

While neither aldehyde reactions with water nor the selfreaction (including aldol condensation) are predicted to efficiently form aqSOA, interactions of aldehydes with inorganic compounds such as ammonium leading to imidazoles have been suggested to be thermodynamically and kinetically favored (Kua et al., 2011). Several laboratory experiments confirm the reaction of glyoxal and methylglyoxal with ammonium (Noziere et al., 2009; Shapiro et al., 2009) and with monomethylamine and amino acids in the absence of photochemical oxidants (De Haan et al., 2009a, c, 2010). Oligomeric products composed of only $\mathrm{C}, \mathrm{H}$ and $\mathrm{O}$ in those experiments were explained by $\mathrm{NH}_{4}^{+}$catalysis (Noziere et al., 2009, 2010a). Empirical expressions of the rate constant of the glyoxal/ammonium reaction show a decrease with increasing pH (Noziere et al., 2009; Yu et al., 2011), i.e. opposite to the trend for organosulfate formation (Sect. 2.1.1).

Reactions between ammonium (amines, amino acids) and (methyl)glyoxal are likely to occur in evaporating cloud droplets, i.e. after glyoxal and methylglyoxal dissolve into the relatively large aqueous volume of cloud droplets and as water evaporation increases the concentrations of the nitrogen containing solutes (i.e. mostly ammonium). This mechanism implies that the reaction between volatile, water-soluble organics has to occur faster than the drop evaporation (De Haan et al., 2009b, 2010). The time scales of these reactions are much longer than for photochemical reactions $\left(k=0.3 \mathrm{M}^{-1} \mathrm{~s}^{-1}, k<0.12 \mathrm{M}^{-1} \mathrm{~s}^{-1}, k \leq 5 \times 10^{-6} \mathrm{~s}^{-1}\right.$ for reactions of glyoxal with amines and amino acids and the methylglyoxal reaction with ammonium, respectively, Table 2). Thus, it can be expected that their contribution to aqSOA is small; however, the particular structure and properties of the products (e.g. imidazoles) might be possibly used as aqSOA tracers.

\subsection{Caveats of laboratory experiments}

Laboratory studies as described in the previous sections represent idealized systems, i.e. the aqueous solutions do not reflect the complex mixture of organic and inorganic aerosol constituents as found in cloud droplets and aerosol particles. In addition, some of the experiments were performed under conditions that are not necessarily atmospherically relevant. However, only such conditions and the simplicity of the reaction systems allow the identification of products and mechanisms by the applied analytical methods. While the concentration of a single compound might be relatively small, the sum of all (organic) compounds might add up to several moles per liter. Organic radicals are likely to form from the reaction of $\mathrm{OH}$ radical with this complex mixture, creating a more complex array of HMWC than one would see in experiments with a single compound (e.g. glyoxal).

While a homogenously mixed aqueous phase might be a good proxy for cloud water, it seems likely that in aerosol particles different phases exist whose solutes might not efficiently interact with each other. The smaller abundance of different solutes in laboratory solutions might prevent the formation of different phases (e.g. separation of hydrophobic compounds, water-soluble organics and inorganic ions, Marcolli and Peter, 2005; Zuend et al., 2008; Bertram et al., 2011; Smith et al., 2011) and thus maximize the interactions of reactants within the condensed phase. In an organic phase, the formation of HMWC slows down with increasing 
Table 2. Summary of experimental conditions, kinetic data and products from dark (non-photochemical) reactions in laboratory experiments leading to aqSOA.

\begin{tabular}{|c|c|c|c|c|c|c|}
\hline & $\begin{array}{l}\text { Organic } \\
\text { reactant } \\
\text { concentration }\end{array}$ & Reactant/Solutes & Rate constant & Products & Comments & Reference \\
\hline \multirow[t]{7}{*}{ Glyoxal } & $\sim 0.1 \mathrm{M}$ & $5 \mathrm{M}$ Amm Sulf & $\begin{array}{l}100 \mathrm{M}^{-1} \mathrm{~s}^{-1} \\
0.1 \mathrm{M}^{-1} \mathrm{~s}^{-1 *}\end{array}$ & & $\begin{array}{l}\text { Fitted rate constant for gly- } \\
\text { oxal oligomerization (for- } \\
\text { ward/back reaction) }\end{array}$ & $\begin{array}{l}\text { Volkamer et al. (2009); } \\
\text { Ervens and Volkamer } \\
(2010)\end{array}$ \\
\hline & $1 \mathrm{M}$ & Amine & $0.3 \mathrm{M}^{-1} \mathrm{~s}^{-1}$ & Imine oligomers & & De Haan et al. (2009c) \\
\hline & $0.1-1 \mathrm{M}$ & Amino acids & $\begin{array}{l}4.5 \times 10^{-4}<k \\
{\left[\mathrm{M}^{-1} \mathrm{~s}^{-1}\right]<} \\
0.12\end{array}$ & $\begin{array}{l}\text { Acetal oligomers, } \\
\text { Imidazoles }\end{array}$ & Depending on amino acid & De Haan et al. (2009a) \\
\hline & & $\mathrm{NH}_{4}^{+}$ & $\begin{array}{l}2 \times 10^{-10} \\
\exp \left(1.5 \cdot a_{\mathrm{NH}_{4}}\right) \\
\cdot \exp (2.5 \cdot \mathrm{pH}) \\
\mathrm{M}^{-1} \mathrm{~s}^{-1 *} \\
\end{array}$ & $\begin{array}{l}\text { Iminium intermedi- } \\
\text { ates, Imidazoles }\end{array}$ & $\begin{array}{l}\text { Empirical expression based } \\
\text { on laboratory studies }\end{array}$ & Noziere et al. (2009) \\
\hline & $1.5 \mathrm{M}$ & $\mathrm{NH}_{4}^{+}(1 \mathrm{M})$ & $\begin{array}{l}(2.01 \pm 0.4) \\
\times 10^{-12} \mathrm{M}^{-2} \\
\mathrm{~s}^{-1}\end{array}$ & Imidazoles & & Yu et al. (2011) \\
\hline & & & & Dimers and trimers & & Liggio et al. (2005b) \\
\hline & & & & Imidazoles & $\begin{array}{l}\text { Prediction of thermody- } \\
\text { namically and kinetically } \\
\text { favored products }\end{array}$ & Kua et al. (2011) \\
\hline \multirow[t]{4}{*}{ Methylglyoxal } & - & - & - & Imidazole, Iminium & & Shapiro et al. (2009) \\
\hline & $2 \mathrm{M}$ & $\mathrm{NH}_{4}^{+}$ & $\leq \underset{10^{-6} \mathrm{M}^{-1} \mathrm{~s}^{-1 *}}{ }$ & $\begin{array}{l}\text { Oligomeric amino } \\
\text { compounds and } \\
\text { organosulfates }\end{array}$ & & Sareen et al. (2009) \\
\hline & $1 \mathrm{mM}$ & $\begin{array}{l}0.01-0.1 \mathrm{mM} \\
\left(\mathrm{NH}_{4}\right)_{2} \mathrm{SO}_{4}, \\
\mathrm{Na}_{2} \mathrm{SO}_{4}, \text { or } \\
\mathrm{H}_{2} \mathrm{SO}_{4}\end{array}$ & & $\begin{array}{l}\text { Oligomers of hydro } \\
\text { ketones }\left(\mathrm{C}_{3} \mathrm{H}_{4} \mathrm{O}_{2}\right)\end{array}$ & $\begin{array}{l}\text { Time scale of product } \\
\text { formation } \sim 1 \mathrm{~h}\end{array}$ & Yasmeen et al. (2010) \\
\hline & - & $\mathrm{NH}_{4}^{+}$ & & Imidazoles & $\begin{array}{l}\text { Theoretical calculations of } \\
\text { prediction of thermody- } \\
\text { namic kinetic feasibility }\end{array}$ & Kua et al. (2011) \\
\hline $\begin{array}{l}\text { Glyoxal + } \\
\text { Methylglyoxal }\end{array}$ & $2 \mathrm{M}$ (total) & $\begin{array}{l}3.1 \mathrm{M} \\
\left(\mathrm{NH}_{4}\right)_{2} \mathrm{SO}_{4}\end{array}$ & & $\begin{array}{l}\text { Light absorbing } \\
\text { hemi acetal, aldol } \\
\text { condensation } \\
\text { products }\end{array}$ & & Schwier et al. (2010) \\
\hline MACR & $2-5 \mu \mathrm{M}$ & $\sim \mu \mathrm{M} \mathrm{O}_{3}$ & $0.003 \mathrm{~s}^{-1}$ & $\begin{array}{l}\text { Hydroxy methyl- } \\
\text { hydroperoxide, } \\
\mathrm{HOCH}_{2} \mathrm{OOH}, \\
\text { methylglyoxal }\end{array}$ & $\begin{array}{l}\text { Pseudo-first order } k \text { with } \\
\text { MACR in excess }(\tau=5 \\
\min )\end{array}$ & Chen et al., (2008) \\
\hline \multirow[t]{2}{*}{ MVK } & & & $\leq 3 \mathrm{M}^{-1} \mathrm{~s}^{-1}$ & $\begin{array}{l}\text { Aldol condensation } \\
\text { products }\end{array}$ & Aldol condensation & Noziere et al. (2006) \\
\hline & $2-5 \mathrm{mM}$ & $\sim \mu \mathrm{M} \mathrm{O}_{3}$ & $4.4 \times 10^{4} \mathrm{M}^{-1} \mathrm{~s}^{-1}$ & $\begin{array}{l}\text { Pyruvic, malonic, } \\
\text { oxalic acid, methyl- } \\
\text { glyoxal, glyoxal, } \\
\text { and their oligomers }\end{array}$ & & Chen et al. (2008) \\
\hline $\begin{array}{l}\text { Epoxide } \\
\text { hydrolysis }\end{array}$ & - & & $\begin{array}{l}0.074<k \\
{\left[\mathrm{M}^{-1} \mathrm{~s}^{-1}\right]} \\
<15\end{array}$ & $\begin{array}{l}\text { Aldol condensation } \\
\text { products }\end{array}$ & $\begin{array}{l}\text { Theoretical estimate based } \\
\text { on generic epoxide }\end{array}$ & $\begin{array}{l}\text { Minerath and Elrod } \\
\text { (2009) }\end{array}$ \\
\hline
\end{tabular}

* These rate constants are used in the box model studies in Sect. 4. 
product formation since the condensed phase becomes more viscous ("glassy") and prevents efficient reactant uptake into and transport within this phase (Shiraiwa et al., 2010; Virtanen et al., 2010; Ziemann, 2010; Pfrang et al., 2011; Pöschl, 2011). In contrast, an aqueous aerosol phase containing oxidized and hygroscopic compounds might allow more efficient mixing and oxidation (Cappa et al., 2011). Phase separation and the presence of surface active compounds are likely to affect transport (evaporation, uptake, diffusion) and reaction rates in ambient particles in ways that are not captured in the simple mixtures used in laboratory experiments.

Laboratory experiments that simultaneously measured gas and particle phase concentrations of glyoxal and methylglyoxal upon oxidation of aromatic compounds have shown that their particulate fraction is $4-5$ orders of magnitude higher than predicted based on thermodynamic equilibrium (Healy et al., 2008, 2009). The reason for this enhanced partitioning is not fully clear; however, it implies that chemical and/or physical effects in aqueous seed aerosol decrease the effective vapor pressure and lead to higher organic concentrations than in pure water. Some of these deviations might be due to analytical issues or sampling artifacts (Turpin et al., 2000). At least some extraction and chemical analysis methods lead to the "break-up" of oligomers and the particulate fraction might reflect not only the carbonyls but also their oligomers. Thus, laboratory experiments with high organic concentrations seem to be a good proxy for aerosol water.

While in laboratory experiments, the aqueous phase $\mathrm{OH}$ is usually produced from $\mathrm{H}_{2} \mathrm{O}_{2}$ photolysis, a major source of the $\mathrm{OH}$ radical in cloud water is the uptake from the gas phase. Model and laboratory studies have shown that as much as about $1 / 3$ rd of the $\mathrm{OH}$ radical found in clouds is formed from aqueous reactions (Arakaki and Faust, 1998; Ervens et al., 2003a). Aqueous phase reactants that form $\mathrm{OH}$ radical (e.g. ferric ion (Fenton reaction) (Arakaki and Faust, 1998), $\mathrm{H}_{2} \mathrm{O}_{2}$ and nitrate, Zellner et al., 1990) are present in considerably higher concentrations in particles, likely enhancing the photochemical formation of $\mathrm{OH}$ in the condensed phase. Evidence of efficient $\mathrm{OH}$ and $\mathrm{H}_{2} \mathrm{O}_{2}$ formation in particles has been recently reported at urban and rural sites in the San Joaquin Valley (Shen and Anastasio, 2011; Shen et al., 2011). Hydrogen peroxide levels in aerosol water exceed predictions based on Henry's law equilibrium by up to two orders of magnitude since aqueous phase processes represent a continuous, significant source of $\mathrm{H}_{2} \mathrm{O}_{2}$ (Arellanes et al., 2006; Y. Wang et al., 2010). In addition, enhanced rates of organic oxidation reactions in aerosol water lead to a faster recycling of $\mathrm{OH}$. This, and uncertainties in $\mathrm{OH}$ radical sinks, make concentrations of $\mathrm{OH}$ radicals in aerosol water highly uncertain. Different transport processes into and inside aerosol particles, high solute concentrations, chemical complexity and uncertain oxidant levels complicate efforts to understand and simulate aqueous chemistry in ambient aerosols.

\subsection{Aerosol properties of laboratory-derived aqSOA}

\subsubsection{CCN properties: surface tension $\sigma$ and hygroscopicity $\kappa(\propto \mathrm{O} / \mathrm{C}$ ratio $)$}

Products of the dark reaction of ammonium, in the absence of oxidants, with glyoxal, glyoxal-methylglyoxal or methylglyoxal-acetaldehyde mixtures show distinct surface tension $\sigma$ suppression as compared to pure water $(\Delta \sigma \sim 20$ $35 \%$ ) at molar carbon concentrations due to the oligomeric character of the products with hydrophobic and hydrophilic entities (Sareen et al., 2009; Noziere et al., 2010b; Schwier et al., 2010; Li et al., 2011). It has been speculated that an efficient condensation of surface active gas phase species on deliquesced aerosol particles might be sufficient to form a surface active film that suppresses the surface tension (Romakkaniemi et al., 2011); however, no observed data can support this mechanism yet.

For aqSOA formation to be substantial, precursor compounds must have high water-solubilities (and/or high concentrations); this suggests that aqSOA will necessarily have high polarity and $\mathrm{O} / \mathrm{C}$ ratios. While gasSOA usually has $\mathrm{O} / \mathrm{C}$ ratios of 0.3-0.5 (Aiken et al., 2008; Massoli et al., 2010; Lambe et al., 2011), aqSOA products have higher $\mathrm{O} / \mathrm{C}$ ratios since the precursors are already highly oxygenated: $\mathrm{O} / \mathrm{C}_{\text {glyoxal }}=1-2$ (depending on hydration), $\mathrm{O} / \mathrm{C}_{\text {methylglyoxal }}=1.5$, leading to aqSOA with $\mathrm{O} / \mathrm{C}=2$ (oxalate) in cloud-relevant solutions, and $\mathrm{O} / \mathrm{C} \sim 1$ at aerosolrelevant concentrations (Altieri et al., 2008; Perri et al., 2009). Dark reactions yield products with O/C ratios of 0.51.5 (Noziere et al., 2009; Sareen et al., 2009; Shapiro et al., 2009) which is on average lower than those observed in photochemical aqueous phase experiments but still higher than the average $\mathrm{O} / \mathrm{C}$ ratios of chamber-derived gasSOA. $\mathrm{RH}$ at which phase separation of aqueous and organic phases (SRH) occurs has been parameterized as a function of the $\mathrm{O} / \mathrm{C}$ ratio of the organic fraction and the organic/inorganic (sulfate) ratio (Bertram et al., 2011).

The hygroscopicity of particles - represented by the hygroscopicity parameter $\kappa$ (Petters and Kreidenweis, 2007) correlates with the $\mathrm{O} / \mathrm{C}$ ratio (Jimenez et al., 2009; Lambe et al., 2011). Extrapolating this linear $\kappa-\mathrm{O} / \mathrm{C}$ relationship to products found in glyoxal and methylglyoxal aqSOA experiments suggests that aqSOA will be more hygroscopic than gasSOA, with $\kappa$ of $\sim 0.15-0.6$, i.e. with an upper limit that is comparable to ammonium sulfate. This prediction agrees well with the hygroscopic growth factor (GF) measurements of MACR-derived aerosol aqSOA of GF $\sim 1.4$ at $\mathrm{RH}=90 \%$ (Michaud et al., 2009). Extrapolating the reported GF-O/C (at RH $=95 \%$ ) correlation by Jimenez et al. (2009) to $\mathrm{RH}=90 \%$ yields approximately $\kappa($ aqSOA $) \sim 0.2$.

Sensitivity model studies of CCN activity over ranges of $\kappa$ and $\sigma$ suggest that (i) in cloud water and dilute aerosol water as encountered near cloud base where droplet activation occurs, organic solute concentrations are much lower 
$(\sim \mu \mathrm{M}-0.1 \mathrm{mM})$ and $\sigma$ suppression due to organics is likely negligible and (ii) high molecular weight and reduced surface tension offset each other resulting in $\mathrm{CCN}$ properties for aqSOA similar to those of ammonium sulfate (Ervens et al., 2005; Padro et al., 2010). Many additional studies have confirmed a weak dependence between CCN composition and cloud droplet number concentration (e.g. Feingold, 2003; Rissman et al., 2004; Reutter et al., 2009). Thus, while the physicochemical properties of aqSOA in terms of CCN ability might be approximated by inorganic solutes, the addition of hygroscopic aqSOA mass, in addition to sulfate, to the droplet mode of an aerosol population will increase particle sizes and thus has implications in terms of direct and indirect aerosol effects.

\subsubsection{Optical properties}

The semidirect and direct aerosol effects due to light absorption by organics ("brown carbon") are not - or only very crudely - included in climate models. Several reactions discussed in Sects. 2.1 and 2.2 yield light-absorbing products that could contribute to atmospheric brown carbon (Sareen et al., 2009; Shapiro et al., 2009). Experiments of glyoxal with ammonium yield yellow-brownish solutions that stem from the formation of C-N containing products (Debus, 1858; Galloway et al., 2009; Sareen et al., 2009; Shapiro et al., 2009; Trainic et al., 2011). Absorption measurements show absorption at $\lambda=209 \mathrm{~nm}$ immediately after mixing the compounds (Noziere et al., 2009) and a band that builds up over several hours at $\lambda=290 \mathrm{~nm}$. Spectra from the same reaction system over longer time scales revealed absorption between $300-400 \mathrm{~nm}$ after a few hours of reaction and structure-less absorption spectra after several days. The refractive index $(n)$ for products of the glyoxal and ammonium reaction depends on the particle size but can be described within a range of values $n=(1.57+0 i)$ to $n=(1.7+0.02 i)$ (Trainic et al., 2011).

Photochemical experiments with aromatic compounds (phenol and related compounds) also showed a shift in absorption to longer wavelengths (from $350-\sim 650 \mathrm{~nm}$ ) whereas the precursors show distinct absorption at $\lambda \sim$ $300 \mathrm{~nm}$ (Gelencser et al., 2003; Hoffer et al., 2004; Chang and Thompson, 2010). The evolution of the absorption at longer wavelengths has been explained by the formation of larger conjugated oligomers that exhibit soot-like structures. Such structures cannot be formed in the gas phase in an oxygen-containing atmosphere. Product spectra resembled the spectra of atmospheric HULIS; correlations were observed between absorbing organic mass and RH and the soluble extracts from ambient aerosols associated with biomass burning and SOA (Hecobian et al., 2010), implying formation of aqSOA (Sect. 3.4.2). Even though the data sets for optical properties of aqSOA compounds are sparse, the qualitative observations summarized here suggest that small aqSOA contributions to the total aerosol mass might have dis- tinct effects on the aerosol radiative properties. However, light-absorption is not unique to aqSOA, since also some gasSOA products absorb UV light e.g. nitroaromatics (Jacobson, 1999; Jaoui et al., 2008; Nakayama et al., 2010) at smaller wavelengths and with a stronger wavelengths dependence (Ångstrom exponent) than soot (Kirchstetter et al., 2004). The particle size to which light-absorbing organic carbon is added depends on the formation process (gasSOA, aqSOA) and impacts the overall absorbing/scattering properties of aerosol populations. AqSOA is generally added to larger particles (droplet mode) whereas gasSOA rather adds to smaller particles.

\section{Observations and model studies of aqSOA}

\subsection{Missing SOA source in current models}

Many gasSOA models fail to reproduce total SOA mass and/or specific properties (DeGouw et al., 2005; Heald et al., 2005; Volkamer et al., 2006; Hodzic et al., 2010). While an underestimate of SOA mass can imply an underestimate of precursor concentrations (emissions) or gasSOA yields, underprediction of the $\mathrm{O} / \mathrm{C}$ ratio, correlation with $\mathrm{RH}$, and correlation with aqueous phase chemistry tracers (e.g. sulfate) infer a role for aqSOA.

Water-soluble organic carbon (WSOC) in the free troposphere above North America correlates with sulfate and methanol (Heald et al., 2006). Since sulfate and methanol are known to form predominantly in the aqueous phase and WSOC is predominantly SOA in locations with little biomass burning, the observed correlation between WSOC and aqueous phase tracers suggests that WSOC might be largely composed of aqSOA. In East Asia, SOA predictions were low by $\sim 50 \%$ for the boundary layer but low by a factor $10-100$ in the free troposphere (Heald et al., 2005), suggesting a role for aqSOA formation through cloud processing as a possible mechanism of sustained SOA formation away from emission sources. Addition of aqSOA sources to a regional air quality model improved not only the total mass concentrations and variability for all model runs but also the agreement of observed and predicted vertical profiles of OA mass (Carlton et al., 2008).

\subsection{Evidence of aqSOA based on aerosol size distributions}

Ambient aerosol populations often show two distinct submicron modes $(<0.2 \mu \mathrm{m}$ and $0.5-1 \mu \mathrm{m})$ where the larger (droplet) mode is formed from the smaller (condensation) mode through volume-phase reactions in clouds and wet aerosols (e.g. sulfate formation) (Hering and Friedlander, 1982; John et al., 1990; Meng and Seinfeld, 1994; Kerminen and Wexler, 1995). An abundance of highly oxidized organics and organosulfates in the droplet mode has been observed in several locations (e.g. Pickle et al., 1990; Blando et al., 
1998). A shift in the carbonyl size distribution to a larger median at high RH has also been observed (Maria et al., 2004). Size resolved measurements of OA, sulfate and nitrate in Los Angeles during marine influence and humid conditions show an abundance of low-volatility oxygenated organics, sulfate and nitrate in the droplet mode (Fillo et al., 2003). These observations provide strong evidence that the organic aerosol at this time was either (1) formed in the aqueous phase or (2) present in condensation mode particles that grow into the droplet mode by aqueous sulfate and/or nitrate formation. The fact that the highest OA mass concentrations were observed when the OA was present in the droplet mode suggests the former, an aqSOA formation process. During periods of clear dry air and intense photochemical activity condensation mode OA dominated, characteristic of the gasSOA route. The modality of SOA reflects its formation mechanisms that have been observed and predicted for the aqueous phase production of sulfate (Hoppel et al., 1994; Feingold and Kreidenweis, 2000). GasSOA models do not reproduce the observed bimodality of organic aerosol mass (Pandis et al., 1993).

\subsection{AqSOA formation in cloud droplets}

\subsubsection{Observation and prediction of oxalate as a proxy of aqueous phase processing}

It is well established that globally the majority $(70 \%)$ of atmospheric sulfate is formed in cloud droplets and only a minor fraction originates from condensation of $\mathrm{H}_{2} \mathrm{SO}_{4}$ on particles or from formation in aerosol water (Sievering et al., 1992; Seinfeld and Pandis, 1998). Enhanced sulfate concentrations are found in the cloud-processed droplet mode. In such particles, small dicarboxylic acids are often found internally mixed with sulfate (Yao et al., 2003, 2005; Huang et al., 2006; Sorooshian et al., 2006), pointing to their efficient formation during cloud-processing. Oxalate, the smallest dicarboxylic acid (salt) is formed from aqueous oxidation of several precursor compounds (Warneck, 2003; Ervens et al., 2004; X. H. Huang et al., 2011) and it has been found to be the most abundant individual organic compound in organic aerosol (Neusüss et al., 2000).

Oxalate can be routinely measured by ion chromatography of integrated filter samples, or equivalent online systems (e.g. particle-in-liquid-sampler (PILS), Orsini et al., 2003), along with inorganic ions, providing robust data sets for a wide variety of atmospheric conditions. Comparisons of parcel model results with measurements show that chemical aqueous phase processes in cloud water can explain enhanced in-cloud and above-cloud oxalate-to-sulfate ratios compared to below-cloud ratios (Sorooshian et al., 2007). During the ICARTT experiment flights over Ohio and surrounding areas, inorganic ions and oxalate were measured in cumulus clouds with thicknesses between 500-700 m. In model calculations, it was assumed that sulfate formation could be appro- priately reproduced and thus predicted sulfate/oxalate ratios were compared to measurements (Sorooshian et al., 2006). The general agreement of the absolute sulfate and oxalate masses in this study as well as their ratios gave confidence in the understanding of in-cloud oxalate formation. During CARMA I, a field campaign designed to study marine stratocumulus off the coast of Monterey, CA, oxalate predictions were higher by a factor of 10 (total predicted oxalate mass $210 \mathrm{ng} \mathrm{m}^{-3}$ ) than the observed ones (Crahan et al., 2004). The discrepancy was ascribed to missing wet deposition or particle removal from the clouds; while not considered by these authors, chemical losses (oxidation by $\mathrm{OH}$ or photolysis of metal complexes in the aqueous phase) may also contribute to oxalate losses (e.g. Ervens et al., 2004; Kawamura et al., 2010). Thus, the aqueous phase might be also a chemical sink for organic phase species and not only be a sink due to drop deposition and removal as it has been discussed in fog studies, e.g. Herckes et al. (2007). A global modeling study concluded that in-cloud net formation (i.e. including oxidation to $\mathrm{CO}_{2}$ ) could explain the atmospheric abundance of oxalate (Myriokefalitakis et al., 2011).

While the vapor pressure of oxalic acid does not suggest it, roughly $90 \%$ of oxalate is found in the particle phase (Baboukas et al., 2000; Yao et al., 2002). This behavior can be explained by salt or complex formation (ammonium, potassium, metal ions, Furukawa and Takahashi, 2011); increased oxalate concentrations in (alkaline) dust and biomass burning particles confirm this conclusion since at higher $\mathrm{pH}$, salt formation is favored (Yao et al., 2002; Sullivan and Prather, 2007; Moffett et al., 2008). Back trajectories of dust particles, internally mixed with oxalate, revealed that these particles were not cloud-processed but that they were aged due to condensation of soluble species onto the dust particle surface. Hygroscopic material on aged particles provides liquid water on the particles (aerosol water) (Yao et al., 2002) and thus might also explain oxalate in the coarse mode of marine particles which cannot be explained by in-cloud processes (Rinaldi et al., 2011). Because the vapor pressure of oxalic acid is much higher than that of oxalate salts, this species can be transported in the gas phase (regardless of how it forms), and react with anions in dust and sea salt particles.

The total contribution of oxalic acid to the total OA fraction usually does not exceed a few percent (e.g. Kawamura et al., 1996b, 2003) and is only one of many products formed through aqueous chemistry. However, the numerous data sets for oxalate and the availability of detailed chemical mechanisms of its formation pathways make it a good tracer to test our understanding of aqueous phase processing of small organic molecules.

\subsubsection{Observed and predicted larger $\left(>\mathrm{C}_{2}\right) \mathrm{aqSOA}$ products}

Larger dicarboxylic acids have been found internally mixed with oxalate, which suggests that their formation pathways 
are connected (e.g. Yao et al., 2003, 2005; Huang et al., 2006; Sorooshian et al., 2006). Specifically, correlations have been observed of oxalate with sulfate, malonate $\left(\mathrm{C}_{3}\right)$ and succinate $\left(\mathrm{C}_{4}\right)$ in aerosol particles (e.g. Kawamura et al., 2000, 2003; Narukawa et al., 2003; Jung and Kawamura, 2011). Large dicarboxylic acids can form smaller acids including oxalate through aqueous oxidation. In addition, $>\mathrm{C}_{2}$ diacids can form from smaller compounds through aqueous organic radical-radical reactions in the high organic concentrations found in wet aerosols. While a motor vehicle source of small dicarboxylic acids has been implied in early studies (Kawamura and Kaplan, 1987; Kawamura et al., 1996a), more recent studies do not find any correlation of dicarboxylic acids with traffic markers (NO, $\mathrm{NO}_{2}$ ) (Martinelango et al., 2007). In addition to dicarboxylic acids, recent size-resolved measurements also show a predominance of HMWC in the droplet mode (Lin et al., 2010b), suggesting concurrent formation of HMWC through aqueous chemistry. Correlations of HMWC with potassium imply the formation in biomass burning plumes that include aged aerosol particles (Lin et al., 2010a).

A related measure of the amount of highly oxygenated OA is the signal of the mass-to-charge ratio $\mathrm{m} / z=44\left(\mathrm{CO}_{2}^{+}\right)$as obtained from aerosol mass spectrometer (AMS) measurements, which is proportional to the number of acid functionalities in the organic mass fraction. A recent study has shown that cloud droplet residuals (at the Pacific Coast and in continental air masses) show highest correlations with $m / z=44$, the oxalate mass and the total organic acid mass to the total organic mass as compared to aerosol masses that were not processed by clouds (Sorooshian et al., 2010). Such studies corroborate conclusions regarding enhanced organic aerosol concentrations in regions of cloud outflow (Peltier et al., 2008).

The implementation of in-cloud aqSOA formation into a regional air quality model (CMAQ) to simulate SOA formation over northeastern US resulted in a much better agreement between predictions and aircraft measurements of WSOC (Carlton et al., 2008), despite a very crude estimate of glyoxal conversion into aqSOA (using a fixed yield of $4 \%$ ). Not only did the bias in the total predicted SOA mass to observations decrease (from $-64 \%$ to $-15 \%$ ), but the model also captured better the temporal variability in OA, especially for flights through clouds. Using the same model (CMAQ) to simulate SOA formation in the same region, but using an explicit aqueous phase mechanism of organic acid formation in clouds from glyoxal and methylglyoxal, aqSOA formation was predicted to account for an overall SOA mass increase of $27 \%$ for rural scenarios and $7 \%$ for anthropogenically influenced areas (Chen et al., 2007). In the same study it was also found that aqSOA formation in clouds was quite uniform at the surface and in free troposphere layer $\left(0.28 \mu \mathrm{g} \mathrm{m}^{-3}\right.$ and $0.25 \mu \mathrm{g} \mathrm{m}^{-3}$, respectively). These authors concluded that aqSOA formation might be in general more important for biogenically-impacted regions since glyoxal and methylgly- oxal are formed in higher yields from isoprene than from anthropogenic emissions. Of course, anthropogenic emissions can alter gas phase chemistry (e.g. through $\mathrm{NO}_{\mathrm{x}}$ ), oxidant production and aerosol water concentrations (i.e. through sulfate formation), all of which are important to aqSOA formation. Note both of these modeling studies neglected aqSOA formation in aerosol water.

\subsection{AqSOA formation in aerosol water}

\subsubsection{AqSOA tracer compounds}

HMWC are mainly formed in aerosol water as opposed to cloud water as the rates of self-reactions of organics (oligomerization, accretion reactions) are negligible in dilute (cloud) water (Sect. 2). Because of the different types of reactions in concentrated and dilute aqueous phase, aqSOA mass formation rates $\left[\mathrm{ng} \mathrm{m}_{\text {gas }}^{-3}\right.$ ] do not scale with the liquid water content (LWC) but have high overall rates in both aqueous regimes. This transition from dilute to concentrated aqueous phase chemistry is unique to aqSOA formation. Sulfate has only negligible formation rates $\left[\mathrm{ng} \mathrm{m}_{\mathrm{g}}^{-3}\right]$ in the small volume of aerosol water and thus its formation rates in aerosols are much smaller than in clouds (Sievering et al., 1992; Meng and Seinfeld, 1994). Mass formation in aerosol water results in a similar size modification of an aerosol population (mass addition to the droplet mode) as cloud processing (Maria et al., 2004) and thus, the existence of HMWC together with sulfate or other cloud-derived material points to aqSOA formation in the aqueous phase.

Many compounds such as di- and oxocarboxylic acids, esters and organosulfur compounds that do not have any (efficient) gas phase sources have been found in rain and cloud water samples (Graedel and Weschler, 1981; Blando and Turpin, 2000); their presence in droplets does not necessarily imply that they have been formed in this dilute aqueous phase. The presence of aldehyde-sulfur(IV) adducts (e.g. hydroxymethane sulfonate) in fog, clouds and aerosols has been interpreted as tracers of aqueous phase chemistry as the corresponding adduct formation does not occur in the gas phase (Munger et al., 1986; Olson and Hoffmann, 1989; Dixon and Aasen, 1999; Lee et al., 2003; Whiteaker and Prather, 2003).

Evidence from laboratory studies suggests that HMWC with acid, sulfur or ester functionalities can be formed in the aerosol aqueous phase and might then dissolve in droplets. In rain and fog water samples, several hundreds of compounds in a mass range of $50<m / z<500$ were identified by ESI-FTICR-MS (Electrospray ionization coupled with Fourier transform ion cyclotron resonance mass spectrometry) showing series of oligomers with compounds that differ by mass fragments of $\mathrm{C}_{3} \mathrm{H}_{4} \mathrm{O}_{2}(\beta$-hydroxy ketones) (Altieri et al., 2009; Mazzoleni et al., 2010), i.e. the same fragments that have also been identified in laboratory experiments pointing to the oligomerization of carboxylic and hydroxycarboxylic acids (Tables 1 and 2) (Altieri et al., 2008; Yasmeen et al., 2010). 
HMWC in atmospheric particles and waters comprise a substantial fraction of the water-soluble organic matter (Fuzzi et al., 2001; Herckes et al., 2002; Krivacsy et al., 2008; Stone et al., 2009) which was originally attributed to primary sources (Likens et al., 1983). While primary and secondary HMWC are polyacidic, the latter comprise lower average molecular weight and lower aromatic moiety content (Graber and Rudich, 2006). While it is possible that a fraction of this organic matter is formed in different liquid (organic) fractions of an aerosol particle, the high polarity and number of carboxylic acid groups of the identified compounds (Fuzzi et al., 2001; Salma and Lang, 2008), their agreement with laboratory-derived aqSOA products (Sect. 2), and correlation with clearly aqueous-phase-derived species and with the amount of aerosol/cloud liquid water contents suggest that they are mainly formed in droplets and/or aqueous particles. The total bulk masses range from $2-100 \mu \mathrm{g} \mathrm{m}^{-3}$ and up to $60 \%$ of the water-soluble organic matter in ambient and biomass burning aerosol, respectively (Fuzzi et al., 2002; Lin et al., 2010b).

\subsubsection{Correlation of WSOC with RH}

The observed increase in particle-phase water-soluble organic carbon $\left(\mathrm{WSOC}_{\mathrm{p}}\right.$ ) at high $\mathrm{RH}$ may also point to aqSOA formation. In Atlanta, the fraction of total WSOC (gas + particulate) that is present in particles $\left(F_{\mathrm{p}}\right)$ increases sharply at high RH $(>70 \%)$, suggesting a positive correlation with aerosol water (Fig. 2a, c). No relationship was readily observed between $F_{\mathrm{p}}$ and particle organic mass (Fig. 2b) when all data were analyzed together, which would be expected from the gasSOA formation route since gasSOA forms through partitioning of semivolatile species into particulate organic matter (Hennigan et al., 2008a, b, 2009). However, during drier periods ( $\mathrm{RH}<70 \%$ ), which often occur in the afternoon (Fig. 2a), there is evidence for gasSOA since $F_{\mathrm{p}}$ shows a correlation to OC (X. Zhang et al., 2011). Thus, both aqSOA and gasSOA formation might be occuring in Atlanta, possibly at different times of the day. The morning peak in $F_{\mathrm{p}}$ coincides with particulate nitrate and thus the formation of both particulate components might be initiated by $\mathrm{HONO}$ as it acts both as precursor of the $\mathrm{OH}$ radical and NO. Whereas the former is a crucial oxidant to form SOA, the latter becomes further oxidized to $\mathrm{HNO}_{3}$ that partitions to the particle phase.

Based on the measured WSOC gas/particle partitioning in Atlanta, an effective Henry's law constant $K_{\mathrm{H}}{ }^{*}$ $\sim 10^{9} \mathrm{M} \mathrm{atm}^{-1}$ for total WSOC was derived (Hennigan et al., 2009). While not pertaining to a specific compound, this value exceeds all values that are known for the physical solubility of common atmospheric organic compounds and is even higher than any derived from studies that suggest reversible oligomerization (Sect. 2.2); values of this order of magnitude have only been observed for glyoxal/aqSOA partitioning in photochemical laboratory experiments where the application of $K_{\mathrm{H}} *$ strictly does not apply (Volkamer et al., 2009). However, inferring that the observed particulate WSOC mass is indeed photochemically and thus irreversibly formed is somewhat speculative based on the current data set as the bulk OC measurements do not give any information on organic speciation. However, in additional studies organic acids and HMWC have been found to be major components of this fraction which might hint to the presence of photochemically formed oxidation products (Sullivan and Weber, 2006a, b; Miyazaki et al., 2009a).

A similar trend between $\mathrm{WSOC}_{\mathrm{p}}$, nitrate and particle water was also observed during the Environmental Protection Agency (EPA) Southern Oxidants Study (SOS) $\mathrm{PM}_{2.5} \mathrm{Su}-$ persite Project in Atlanta (Lee et al., 2003). Internally mixed organic and nitrate particles showed a maximum in the morning when RH was high. The same correlations were also observed in Mexico City during the MILAGRO experiment (Hennigan et al., 2008a). WSOC $\mathrm{p}_{\mathrm{p}}$ and nitrate were often observed to peak shortly following sunrise when RH was high and photochemical processes began. A smaller maximum of organics was observed in the afternoon associated with internally mixed organic and sulfate particles. These organics are likely formed by different mechanisms (gasSOA formation). As the day progressed during MILAGRO, concentrations of nitrate and $\mathrm{WSOC}_{\mathrm{p}}$ decreased due to boundary layer expansion and evaporation of some fraction of newly formed secondary nitrate and WSOC as RH approached the daily minimum in early afternoon. Only roughly $35 \%$ of the fresh $\mathrm{WSOC}_{\mathrm{p}}$ appeared to be volatile, a fraction considerably less than that for nitrate, which resulted in an increasing WSOC/nitrate ratio, indicating a significant irreversible net aqSOA production in aerosol water (Hennigan et al., 2008a). For the same field experiment, AMS measurements provided the $\mathrm{O} / \mathrm{C}$ ratio as a proxy of the degree of oxygenation of the organic aerosol mass. This ratio agrees well with data from other ambient aerosol samples for the first two weeks $(0.3<\mathrm{O} / \mathrm{C}<0.9, \mathrm{Ng}$ et al., 2010). It is expected that the $\mathrm{O} / \mathrm{C}$ ratio shows an increasing trend at elevated $\mathrm{RH}$ (Fig. 2d, Fast et al., 2007; Hodzic et al., 2010) if the predominant SOA species are composed of aqSOA. The increase of the $\mathrm{O} / \mathrm{C}$ ratio with $\mathrm{RH}$ (Fig. 2e) suggests that not only oxygen is added to preexisting molecules (e.g. heterogeneous oxidation of aerosol components with little change in particle mass, only $\Delta \mathrm{O}$ ) but rather that additional organics are taken up into the increased aqueous volume and further oxidized into aqSOA products that exhibit high O/C ratios (cf. Sect. 2.4.1). The data in Fig. 2e might suggest the expected trend with lowest $\mathrm{O} / \mathrm{C}$ ratios at the lowest $\mathrm{RH}$ even though the linear correlation coefficient is not high. Since the amount of aqSOA and thus the overall $\mathrm{O} / \mathrm{C}$ ratios of the total OA mass depend on the intensity of photochemistry, the highest values can be seen around noon (Fig. 2d). In order to emphasize this correlation, data points that were recorded during the day ( $\sim 06: 00$ a.m. $-\sim 06: 00$ p.m.) are marked by small red points in Fig. 2e. It is obvious that these points show higher O/C 

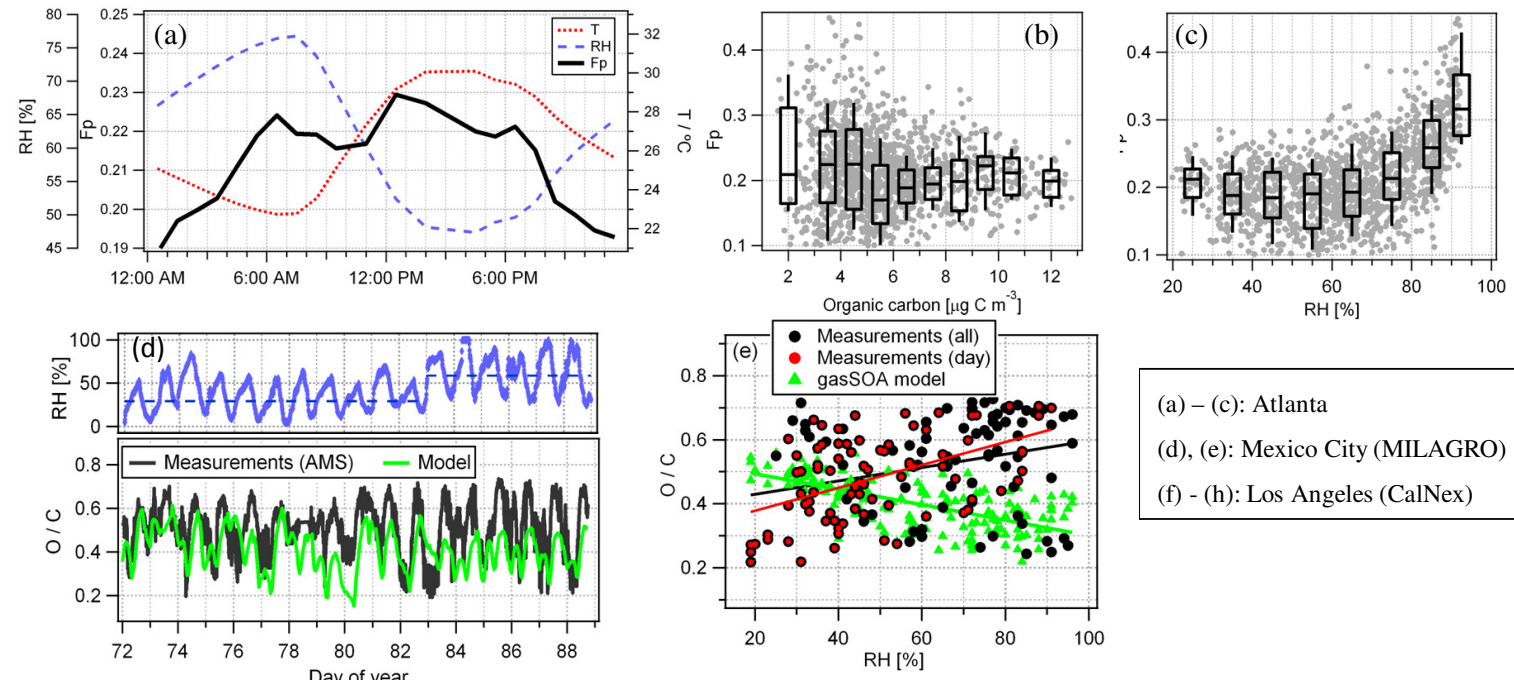
(a) - (c): Atlanta
(d), (e): Mexico City (MILAGRO)
(f) - (h): Los Angeles (CalNex)
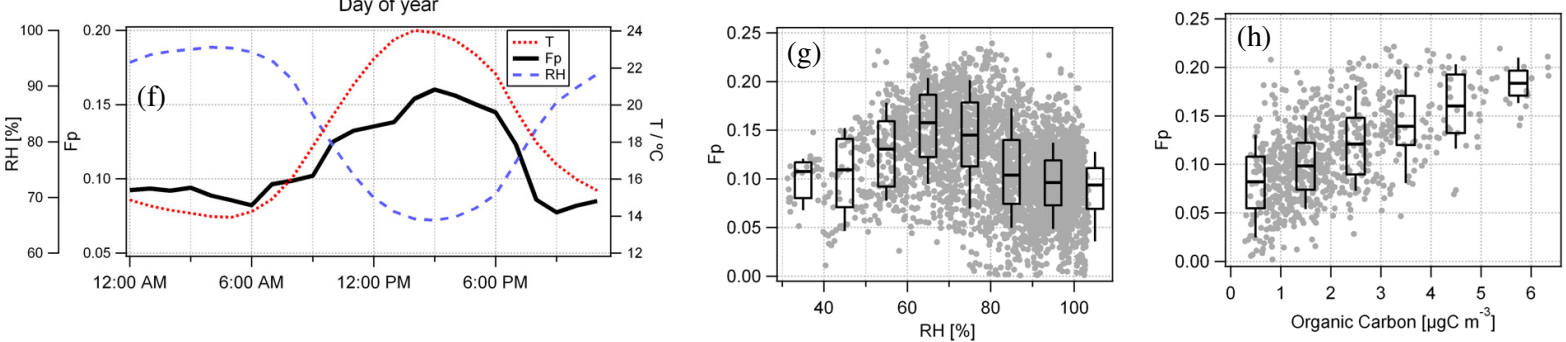

Fig. 2. Observations of organic carbon or related parameters at different locations. Upper panel: Atlanta: (a) averaged diurnal evolution of temperature, RH and WSOC fraction in the particle phase $\left(F_{\mathrm{p}}\right) ;(\mathbf{b}) F_{\mathrm{p}}$ as a function of $\mathrm{RH} ;(\mathbf{c}) F_{\mathrm{p}}$ as a function of total organic carbon Middle panel: Mexico City: (d) temporal evolution of RH and O/C ratio (AMS data and model prediction; Hodzic et al., 2010); (e) observed and predicted $\mathrm{O} / \mathrm{C}$ ratio as a function of RH; black symbols show all data points; red symbols show only data recorded during day time (06:00 a.m.-06:00 p.m.). Bottom panel: Los Angeles: (f) averaged diurnal evolution of temperature, RH and WSOC fraction in the particle phase $\left(F_{\mathrm{p}}\right) ;(\mathrm{g}) F_{\mathrm{p}}$ as a function of $\mathrm{RH}$; (h) $F_{\mathrm{p}}$ as a function of total organic carbon.

ratios and a better correlation with $\mathrm{RH}$ and thus might point to photochemically formed aqSOA products in the aqueous aerosol phase. It should be noted that it is not RH but rather the amount of aerosol water (i.e. a combination of RH and the amount of hygroscopic aerosol mass) that will determine the size of the "aqueous phase reactor" where aqSOA formation can take place. This caveat might explain some of the scatter in Fig. 2e.

The predicted trend from a regional model that only includes gasSOA formation shows the opposite behavior of the O/C ratio and RH relationship (Fig. 2e; Hodzic et al., 2010), which supports once more that gasSOA models do not capture the RH dependence of SOA formation. At the same location (during the MCMA field experiment), the comparison of modeled and observed gas phase glyoxal revealed a "missing sink" of glyoxal as a highly water-soluble, volatile compound together with an unexpected source of SOA (Volkamer et al., 2007) which gave the first observational evidence of aqSOA formation in aqueous particles. Estimates based on this mismatch between modeled and observed glyoxal gas phase concentrations suggest that in Mexico City aqSOA formation from glyoxal in aqueous particles could contribute sub- stantially to total SOA (up to $15 \%$ ) (Volkamer et al., 2007; Dzepina et al., 2011).

The $\mathrm{O} / \mathrm{C}$ ratio is directly related to the ratio of total organic mass to organic carbon (OM/OC) as oxygen is the most abundant heteroatom in organic molecules (Pang et al., 2006). In many model studies, a constant OM/OC ratio is applied to convert from measured $\mathrm{OC}$ to total $\mathrm{OM}$ although it has been shown that it greatly varies depending on the composition of the OM fraction (Turpin and Lim, 2001). For ambient HMWC, a ratio of $\mathrm{OM} / \mathrm{OC}=1.8$ has been determined (Salma et al., 2008). A similarly elevated OM/OC ratio for total OM has been reported for the Southeast US (Simon et al., 2010). While it is possible that this result might be influenced by the assumptions made in the latter study, this finding is also consistent with a large role for aqSOA in this high-RH, photochemically-active location (Hennigan et al., 2009) (Fig. 2a-c).

Measurements in Los Angeles (LA), during the CalNex experiment (http://www.esrl.noaa.gov/csd/calnex/), overall show the opposite trend in terms of WSOC partitioning $\left(F_{\mathrm{p}}\right)$, correlation with RH and OC, as compared to the Southeast US (Fig. 2a-c versus $2 \mathrm{f}-\mathrm{h}$ ). No relationship is observed 
between $F_{\mathrm{p}}$ and RH, (Fig. 2f) as in Atlanta, but a correlation is observed between $F_{\mathrm{p}}$ and OC mass (Fig. $2 \mathrm{~g}$ ), in agreement with the partitioning theory of gasSOA formation. In LA, this points to a much less significant aqSOA contribution, even though RH shows a similar temporal profile with even higher values in LA. One conclusion from the comparison of LA and Southeast US data might be that the higher emissions of biogenic compounds make the southeastern region more conducive to aqSOA routes as compared to the LA basin (X. Zhang et al., 2011). OA measurements at such very different locations are not sufficiently comprehensive to elaborate on any conclusions. In Cairo, a dry, highly anthropogenically influenced location, and in a suburban site in France the formation of water-insoluble SOA has been observed (Favez et al., 2008; Sciare et al., 2011) which might add to evidence that not only the SOA precursor, but also the meteorological conditions, and thus the type of chemical process (aqueous or gas phase) determines the formation and distribution of SOA. Studies in Whistler, Canada, an area that was highly influenced by biogenic emissions show that products of aqueous photochemical reactions can better reproduce the mass spectra of aged secondary organic aerosols (Lee et al., 2011). Significant contributions to WSOC mass have been reported in fog water; the diurnal evolution of the OC/EC ratio suggests an important role of aqSOA formation with highest contribution during morning hours, i.e. when fog still persists and photochemistry starts (Kaul et al., 2011). Firm conclusions on the relative role of precursor compounds and non-chemical effects to the contributions of gasSOA and aqSOA cannot be drawn based on these sparse data sets and warrant future field and model studies.

\subsubsection{Discussion of model approaches to predict aerosol aqSOA}

While several models include some representation of cloud aqSOA formation, data sets of reaction parameters for aerosol aqSOA formation are much less constrained. No comprehensive module has been developed to date that predicts aerosol aqSOA formation based on the reaction parameters summarized in Tables 1 and 2. However, in the following we present the current attempts to estimate the role of the aqueous phase of aerosols and discuss their caveats that could be improved based on the most recent understanding of aerosol aqSOA processes.

Based on vapor pressures, activity coefficients and solubility, it has been predicted that in the South Coast Air Basin of California less than $30 \%$ of condensable gasSOA precursors partition to the aqueous phase of particles as opposed to the (hydrophobic) organic phase (Griffin et al., 2003; Chang et al., 2010). However, these studies did not take into account more volatile water-soluble organics that might dissolve into the aqueous phase (e.g. glyoxal) for further processing. Similar to the trends as identified in LA (Fig. 2f-h), in that model study no (or an inverse) trend between aqSOA and total OA mass was observed.

Extending the most detailed cloud chemistry model, i.e. the chemical aqueous phase radical mechanism (CAPRAM) (Herrmann et al., 2000, 2005; Ervens et al., 2003a) to aerosol water conditions, it was concluded that the aqueous phase formation rates $\left[\mathrm{M} \mathrm{s}^{-1}\right]$ of mono- and multifunctional organic acids by the $\mathrm{OH}$ radical are high in both cloud droplets and aqueous particles (Tilgner and Herrmann, 2010). However, appreciable aqSOA mass formation was only predicted in cloud droplets since the absolute mass conversion [ $\mathrm{ng} \mathrm{m}_{\text {gas }}^{-3}$ ] in aerosol water is small. Similar qualitative conclusions were drawn from global model studies where an irreversible uptake of glyoxal and methylglyoxal into cloud and aerosol water using a reactive uptake parameter $\gamma=0.0029$ (based on laboratory studies by Liggio et al., 2005a, b, Sect. 2) was assumed (Fu et al., 2008, 2009). In these studies, it was concluded that aqSOA formation could enhance the total SOA burden by $60 \%$ and that globally $64 \%$ of aqSOA in the free troposphere is non-biogenic. A reactive uptake coefficient $\gamma$ implies a surface-limited process whereas the most efficient (photochemical) aqSOA formation processes are suggested to occur in the bulk aqueous phase (Sect. 2.1.1). The same approach was used in a global model to analyze the vertical OA profile from several aircraft field studies (Heald et al., 2011). Their model results suggested a significant enhancement of OA at $2-6 \mathrm{~km}$ due to aqSOA formation which was not supported by observations. However, it should be noted that a more sophisticated treatment of aqSOA formation, i.e. distinguishing bulk and surface processes as well as reactions in cloud and aerosol water might lead to a better agreement. In addition, a surfacelimited process would rather be at odds with measured size distributions that show clear processing of droplet mode particles (Hersey et al., 2011).

The minor importance of aqSOA formation in aerosol water in the aforementioned studies is due to the application of identical reaction parameters for cloud and aerosol water. Since LWC in clouds is significantly larger than in aerosols $\left(\sim 0.1<\right.$ LWC(cloud) $\left[\mathrm{g} \mathrm{m}^{-3}\right]<\sim 1 ; \sim 1<$ LWC(aerosol) $\left.\left[\mu \mathrm{g} \mathrm{m}^{-3}\right] \sim 100\right)$, the same chemical bulk reactions will always yield higher aqSOA masses in cloud droplets. However, laboratory studies clearly show that the application of identical reaction parameters for both aqueous regimes is not appropriate since high solute concentrations in aerosol water open additional chemical pathways (oligomerization) that lead to different aqSOA products (Sect. 2).

Global aqSOA prediction in aerosol water applying reversible aqSOA formation from glyoxal $\left(K_{\mathrm{H}}{ }^{*}=2.6 \times 10^{7} \mathrm{M} \mathrm{atm}^{-1}\right)$ (Myriokefalitakis et al., 2008) certainly represents a lower bound of aqSOA since photochemical processes might form aqSOA mass more efficiently and irreversibly (Sect. 2.1). A combination of aqSOA formation in particles (using $\gamma=0.0029$ ) and an in-cloud parameterization similar to Ervens et al. (2008) was 
applied to estimate the aqSOA burden over the continents (Stavrakou et al., 2009). This study concluded that glyoxal loss on aerosol particles is at least as efficient as on cloud droplets or even up to $60 \%$ higher. A recent detailed model study of global oxalate formation by aqueous processes in cloud and aerosol water predicted that more than $90 \%$ of this compound is formed in clouds whereas it was assumed, based on laboratory experiments (Lim et al., 2010), that the photochemical glyoxal oxidation in aerosol water has an oxalate yield of $20 \%$ (Myriokefalitakis et al., 2011).

The summary of these studies shows that none of the models fully captures all conversions of water-soluble organics in aerosol water as summarized in Tables 1 and 2. Most reaction parameters for aerosol aqSOA formation are available for glyoxal and methylglyoxal. However, not only small carbonyl compounds but also alcohols, carboxylic acids, organic peroxides and larger, semivolatile compounds might act as precursors for aqSOA (Fig. 1). While they might alternatively participate in gasSOA formation, their partitioning and further processing in aerosol water will lead to different mass distribution and aerosol properties.

\section{Comparison of gasSOA and aqSOA mass predictions}

\subsection{AqSOA formation in cloud droplets vs aerosol particles}

The model approaches summarized above do not allow a comprehensive comparison of the importance of cloud and aerosol aqSOA formation. In order to provide a first estimate on the extent to which cloud and aerosol chemistry yield aqSOA mass, we simulated these processes in a parcel model. The same model was applied previously to evaluate aqSOA formation in clouds, i.e. with aqueous phase chemistry only considered if $\mathrm{RH} \geq 100 \%$ and $\mathrm{LWC} \geq 0.01 \mathrm{~g} \mathrm{~m}^{-3}$ (Ervens et al., 2004, 2008). Here the model has been extended to account for aerosol aqSOA formation during periods when $\mathrm{RH}<100 \%$. Model simulations were performed over four hours using repeated 1-h trajectories that prescribe meteorological parameters (temperature, pressure, $\mathrm{RH}$ ). $\mathrm{RH}$ as a function of time in the applied trajectories is shown in Fig. 3a for the simulation time between 2.5 and $3.5 \mathrm{~h}$.

Photochemical rate constants for glyoxal and methylglyoxal as derived from experiments at high organic concentrations (Volkamer et al., 2009; Ervens and Volkamer, 2010; Lim et al., 2010; Tan et al., 2010) as well as the reaction of glyoxal with ammonium have been included (Tables 1 and 2 ; reactions marked with ${ }^{*}$ ). Note that the lumped photochemical rate constants used here do not describe a detailed mechanism but are first-order rate constants that have been fitted to the observed temporal aqSOA mass profiles in laboratory experiments. Comparisons of aqSOA mass formation rates using these rate constants and the detailed mechanisms
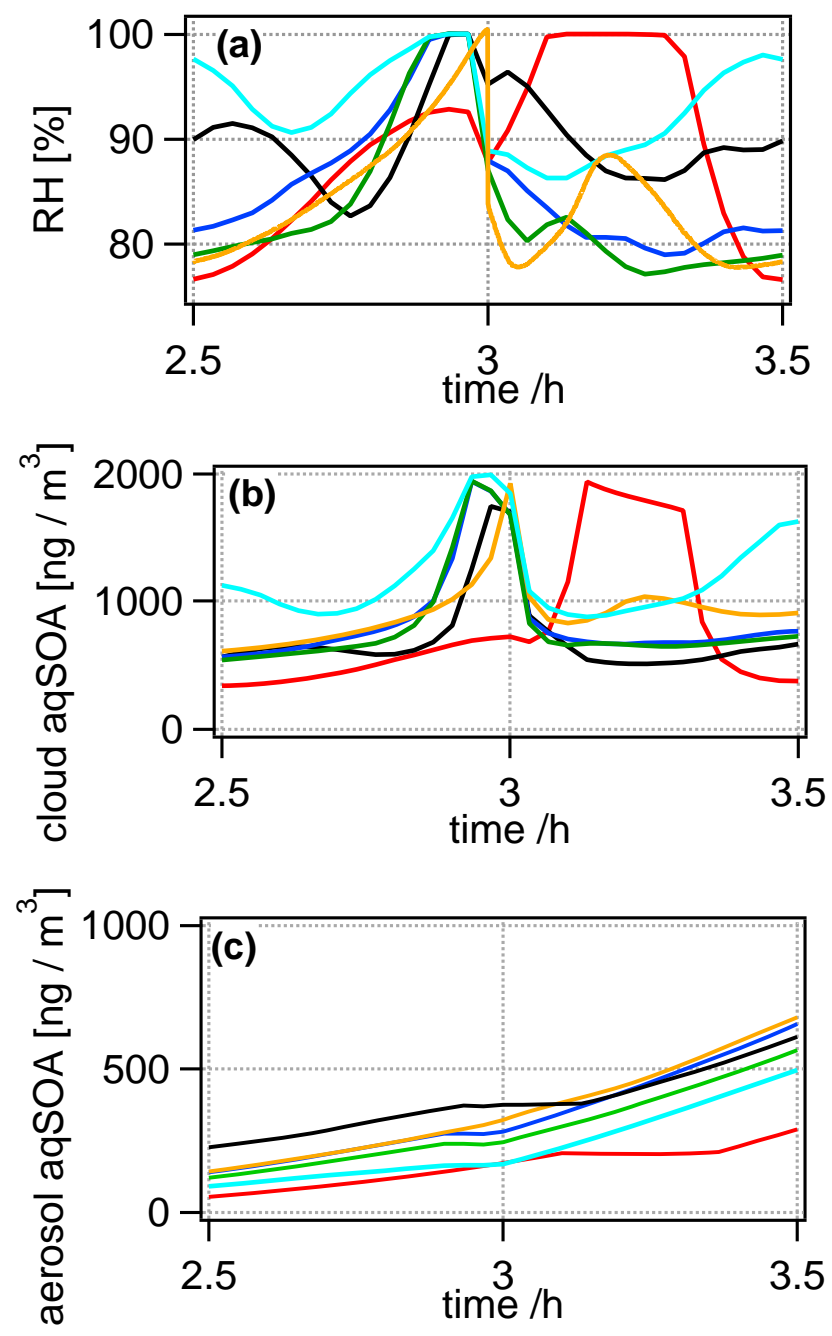

Fig. 3. Results from parcel model studies using six trajectories (differently colored traces) that differ by temporal evolution of meteorological parameters (temperature, pressure, $\mathrm{RH}$, in-cloud time, etc.). The chemical mechanism uses reaction parameters for glyoxal and methylglyoxal as listed in Tables 1 and 2 (processes marked with *). (a) Time profiles of RH for six different trajectories (colorcoded); (b) predicted aqSOA formation in aerosol water; (c) predicted aqSOA formation in cloud water. The prediction of similar aqSOA amounts from both sources is a coincidental result and will strongly depend on time scales parcels spend in/outside of clouds, ambient RH, and cloud LWC.

by Lim et al. (2010) and Tan et al. (2010a) that describe the same reaction system, show good agreement.

In Fig. $3 b$ the predicted cloud aqSOA mass is shown as the sum of oxalic, glyoxylic, glycolic, and pyruvic acid masses that is assumed to remain in the particle phase upon cloud evaporation. If the air parcel is inside the cloud, cloud aqSOA masses of up to $2 \mu \mathrm{g} \mathrm{m}^{-3}$ are predicted; during cloud processing and evaporation part of this mass is oxidized and/or evaporates (Ervens et al., 2008). After 3 cloud cycles, about $1 \mu \mathrm{g} \mathrm{m}^{-3}$ cloud aqSOA is predicted to remain 
in the particles at $\mathrm{RH} \sim 75 \%$. A continuous mass increase of about $1 \mu \mathrm{g} \mathrm{m}^{-3}$ aerosol aqSOA formed during the time when the parcel is outside of clouds is predicted after the same simulation time for all trajectories (differently colored traces in Fig. 3c). The approximately equal amount of aqSOA predicted to form in cloud droplets and aerosol water seems at odds as the aerosol LWC is smaller by several orders of magnitude than cloud LWC. However, as pointed out in Sects. 2 and 3.4.3, there is a transition between dilute (cloud) and concentrated (aerosol) aqueous phase chemistry. Thus, even small concentrations in cloud water can lead to significant mass formation rates (related to gas phase concentrations [ $\left.\mathrm{ng} \mathrm{m}_{\text {gas }}^{-3}\right]$ ) whereas in aerosol water oligomerization reactions lead to higher overall aqSOA formation rates $\left[\mathrm{M} \mathrm{s}^{-1}\right]$ resulting in similar overall aqSOA mass production rates $\left[\mathrm{ng} \mathrm{m}_{\mathrm{gas}}^{-3}\right]$.

In general, the relative contributions of cloud and aerosol aqSOA to the total SOA depend on the time scales air parcels are exposed to supersaturated (clouds) and subsaturated (aerosols) conditions. However, the results in Fig. 3 show that on a comparable time scale aqSOA formation in clouds and aerosol water might be equally efficient. It has been shown that dicarboxylic acids formed in clouds might increase the total organic aerosol mass by up to $10 \%$ (Sorooshian et al., 2010), in agreement with the fraction of these acids to total WSOC. However, the processing time in aerosol water might be much longer (hours - days) than processing in cloud water, as aqueous aerosols do not undergo activation and evaporation cycles of several minutes, but instead can be exposed to cycles of elevated RH through repeated diurnal temperature cycles or changes in altitude. This suggests that the vast majority of aqSOA may form in aerosol water and be comprised of products with higher carbon number than their precursors.

\subsection{Partitioning of aqSOA and gasSOA compounds}

\subsubsection{Concepts of partitioning}

Whereas gasSOA mass is a function of preexisting organic aerosol mass, gasSOA compounds can absorb into, the amount of aqSOA material that can be dissolved in aerosol (or cloud) water depends on the LWC (e.g. Ervens and Kreidenweis, 2007). The formation and partitioning of gasSOA species between the gas and particle phase is described by either the traditional approach that assumes two oxidation products P1 and P2 (2-product model; Odum et al., 1996) or by a more recent approach that includes also semivolatile products and distributes the oxidation products over logarithmically spaced "volatility bins" according to their saturation pressure (volatility basis set (VBS); Donahue et al., 2006). Both approaches ascribe stoichiometric coefficients to the predicted (generic) gasSOA products and the amount of mass that partitions to the particle phase $F_{\mathrm{p}}$ depends on the saturation vapor pressures $C^{*}$ (=inverse of the partition- ing coefficient $K_{\mathrm{p}}$ ) and the amount of organic material in the absorbing aerosol $\left(m_{\text {org }}\right)$ :

$C^{*}=K_{\mathrm{p}}^{-1}=\frac{F_{\mathrm{gas}} \cdot m_{\mathrm{org}}}{F_{\mathrm{p}}}\left[\mu \mathrm{g} \mathrm{m}^{-3}\right]$

Particle phase reactions in aqueous or organic phases might further decrease the vapor pressure of the gasSOA compounds and thus enhance the partitioned fraction, i.e. moving it into a "lower volatility bin" which implies a higher partitioned fraction.

For water-soluble compounds, the Henry's law constant $K_{\mathrm{H}}$ (or $K_{\mathrm{H}}{ }^{*}$, Sect. 2.2) represents the ratio of aqueous and gas phase concentration; thus, the product of $K_{\mathrm{H}}$ and LWC represents a measure that includes the same quantities as $C^{*}$ whereas $m_{\text {org }}$ is replaced by the water mass $m_{\text {water }}$. In order to differentiate $C^{*}$ for gasSOA which is a function of $m_{\mathrm{org}}$, and $C^{*}$ for aqueous phase species, we will refer to the latter to as $C^{*}$ aq. Thus, for both gasSOA and aqSOA the partitioned fraction $F_{\mathrm{p}}$ (similar to Fig. 2) of predicted SOA products can be estimated for assumed organic and water masses, respectively, by

$$
\begin{gathered}
F_{\mathrm{p}}(\text { gasSOA })=\frac{m_{\mathrm{org}} / C^{*}}{1+m_{\mathrm{org}} / C^{*}} \\
F_{\mathrm{p}}(\mathrm{aqSOA})=\frac{\mathrm{LWC} / C_{\mathrm{aq}}^{*}}{1+\mathrm{LWC} / C_{\mathrm{aq}}^{*}}
\end{gathered}
$$

Such predicted fractions $F_{\mathrm{p}}$ do not give any information about the actual SOA mass as it does not include information on the amounts formed from the different precursors (stoichiometric coefficients for gasSOA and time scales for aqSOA). However, the purpose of comparing $F_{\mathrm{p}}$ (gasSOA) and $F_{\mathrm{p}}(\mathrm{aqSOA})$, as done in the following section, is rather to provide a sense of the ability to which precursors and oxidation products might partition.

\subsubsection{Comparison of partitioned gasSOA and aqSOA fractions}

Organic and water masses may be on the same order of magnitude in ambient aerosol, and, under the assumption that both water and organic matter are equally accessible to condensing species, a comparison of the partitioning of individual compounds can be made by applying Eqs. (3-5). In order to show this concept, the partitioning of gasSOA products from benzene, toluene, xylene, and isoprene is shown in Fig. 4a and expressed as the fraction $F_{\mathrm{p}}$ (gasSOA). We show results for both gasSOA approaches (2-Product model, VBS) using $K_{\mathrm{p}}$ values for P1 and P2 from Henze and Seinfeld (2006) and $\mathrm{Ng}$ et al. (2007) and $C^{*}$ values from Tsimpidi et al. (2010). The lower-volatility products from all precursors partition to a significant extent to the particle phase (30$60 \%$ for $m_{\text {org }}=1 \mu \mathrm{g} \mathrm{m}^{-3}$; >60\% for $m_{\text {org }}=10 \mu \mathrm{g} \mathrm{m}^{-3}$ ). 

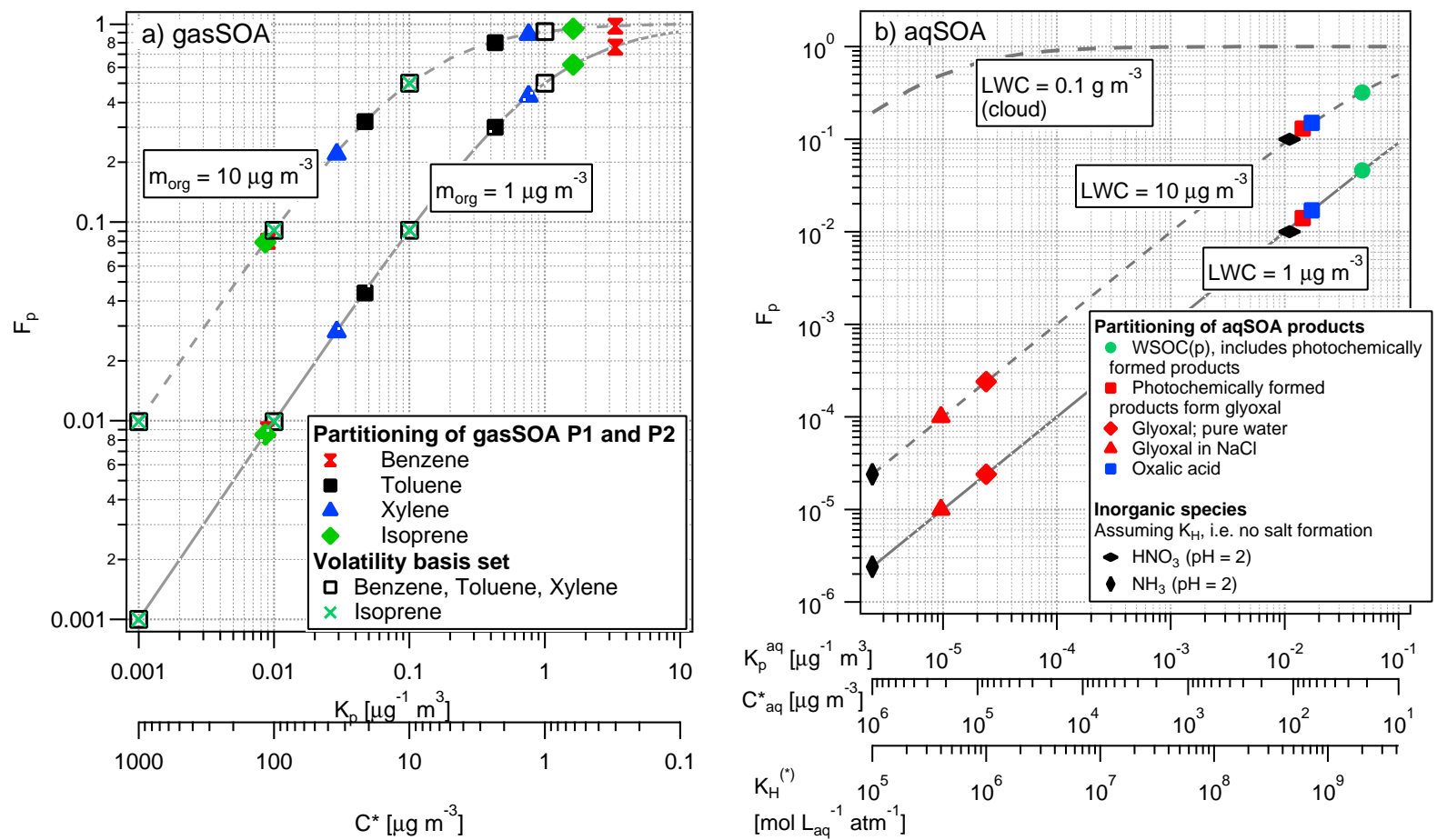

Fig. 4. Particulate fraction $F_{\mathrm{p}}$ as predicted based on different SOA approaches (a) gasSOA is predicted based on 2-product model or VBS and displayed as a function of the partitioning constant $\mathrm{Kp}$ and saturation concentration $\mathrm{C}^{*}$ for different amounts of organic aerosol mass. (b) aqSOA is shown as a function of $K_{\mathrm{H}}\left(\right.$ or $\left.K_{\mathrm{H}}{ }^{*}\right)$. This constant is converted to $K_{\mathrm{p}}^{\mathrm{aq}}$ and $C_{\mathrm{aq}}^{*}$ which corresponds to $K_{\mathrm{p}}\left(C^{*}\right)$ for gasSOA but relates to water instead of absorbing organic material (Sect. 4.2.2). Values are shown for two different aerosol LWC; trends for cloud LWC are only shown as a line.

Predictions using the VBS reveal that some gasSOA products from aromatics might partition to a high extent to the particle phase for any assumed $m_{\text {org. }}$. However, both aromatics and isoprene also produce products with $1000>C^{*}\left[\mu \mathrm{g} \mathrm{m}^{-3}\right]>1$ which result in $F_{\mathrm{p}}$ (gasSOA) $<5 \%$. It should be noted that such compounds might get further processed ("aerosol ageing") and thus decrease their vapor pressure which will move them to smaller $C^{*}$ values.

Fig. $4 \mathrm{~b}$ shows the partitioning $\left(F_{\mathrm{p}}\right)$ of aqSOA products in aerosol water. The highest $F_{\mathrm{p}}(\mathrm{aqSOA})$ value $(30 \%$ and $5 \%$ for $\mathrm{LWC}=10 \mu \mathrm{g} \mathrm{m}^{-3}$ and $1 \mu \mathrm{g} \mathrm{m}^{-3}$, respectively) is predicted based on the observations of the partitioning of total WSOC in Atlanta (Sect. 3.4.2). This fraction might also include photochemically formed products. Photochemically formed glyoxal oxidation products in aerosol water might partition to a few percent $(<10 \%)$ into aerosol water whereas the reversibly formed glyoxal oligomeric products as predicted from effective Henry's law constants by Ip et al. (2009) might not contribute to aerosol mass to a significant extent even if relatively high aerosol LWC is available. Based on the Henry's law constant, oxalic acid might only partition to $\sim 10 \%$ into aerosol water. Observations have shown that oxalate concentrations in the gas phase are negligible and have ascribed enhanced partitioning to complex and/or salt formation which is not captured by the "solubility concept" used in Fig. 4b (Furukawa and Takahashi, 2011). In addition, it should be noted that the application of Henry's law to aerosol water might not be strictly valid since aerosol water does not represent an ideal solution. In a more thorough approach, other thermodynamic parameters such as activity coefficients and fugacity should be taken into account in explicit thermodynamic approaches (Compernolle et al., 2011).

In cloud water, $F_{\mathrm{p}}(\mathrm{aqSOA})$ for all species is much higher and even species with $K_{\mathrm{H}}=10^{5} \mathrm{M} \mathrm{atm}^{-1}$ might partition to a significant extent to the aqueous phase. Such species might include acids (at enhanced $\mathrm{pH}$ ), and small monoaldehydes. However, these species will not necessarily contribute to aqSOA mass upon cloud evaporation as they are too volatile. For comparison, two inorganic aerosol compounds $\left(\mathrm{HNO}_{3}\right.$ and $\mathrm{NH}_{3}$ ) are added to Fig. $4 \mathrm{~b}$ as well. While they will be nearly completely dissolved in cloud water, aerosol water does not represent a significant sink for their total budgets. This estimate does not include the formation of salts in the particle phase which will shift the effective $F_{\mathrm{p}}$ of $\mathrm{HNO}_{3} / \mathrm{NO}_{3}^{-}$and $\mathrm{NH}_{3} / \mathrm{NH}_{4}^{+}$to more efficient partitioning. 


\subsection{Predicted formation of gasSOA and aqSOA from common precursors}

\subsubsection{Definition of gasSOA and aqSOA yields}

The partitioning of individual species does not give any information about the absolute SOA mass as it neglects reaction times and stoichiometric coefficients. Smog chamber experiments report gasSOA yields as the mass ratio of formed SOA mass and the consumed precursor hydrocarbon $(\mathrm{HC})$ mass for a given set of experimental conditions (absorbing aerosol mass, oxidant levels).

$Y(\mathrm{SOA})=\frac{m(\mathrm{SOA})}{\Delta[\mathrm{HC}]}$

In yield parameterizations according to the 2-product model, it is assumed that the condensable gasSOA mass can be represented by two proxy compounds that are formed with stoichiometric factors $\alpha_{1}, \alpha_{2}$ and have partitioning coefficients $K_{\mathrm{p} 1}$, and $K_{\mathrm{p} 2}$, respectively (Odum et al., 1996). The gasSOA yield is constant for a given set of experimental conditions (precursor, $\mathrm{NO}_{\mathrm{x}}$ level, mass loading etc) since chemical loss processes on dry SOA are slow (Molina et al., 2004; Petters et al., 2006) as they only occur on the particle surface and not in the bulk. $\mathrm{NO}_{\mathrm{x}}$ levels in the gas phase determine the fate of peroxy radicals and the product distribution which, in turn, affect the amount of formed condensable species, with preferential peroxide formation at low $\mathrm{NO}_{\mathrm{x}}$ levels (Fig. 5). Parameter sets for $\alpha_{1}, \alpha_{2}, K_{\mathrm{p} 1}$, and $K_{\mathrm{p} 2}$ for various precursors and $\mathrm{NO}_{\mathrm{x}}$ conditions are included in current gasSOA models.

Most aqueous phase laboratory experiments are performed in bulk aqueous phase, i.e. reported "aqSOA yields" refer to the consumed precursor aqueous phase compound (e.g. Carlton et al., 2007; El Haddad et al., 2009; Lim et al., 2010; Perri et al., 2010). Maximum aqSOA yields of up to $100 \%$ from aqueous phase glyoxal (Lim et al., 2010) and nearly $70 \%$ from aqueous phase methylglyoxal (Tan et al., 2010) have been reported; aqSOA yields for aqueous MACR and MVK are significantly smaller with $2-12 \%$ and $5-10 \%$, respectively (El Haddad et al., 2009; Zhang et al., 2010). In all experiments, aqSOA yields were observed to be timedependent with an initial increase and a later decrease due to oxidation of aqSOA products to $\mathrm{CO}_{2}$. Unlike reported gasSOA yields, these reported laboratory-derived aqSOA yields (even for a given processing time) cannot directly be implemented into multiphase models as they only refer to the conversion of the aqueous phase species and thus represent upper limits of the yields related to the gas phase species. Aqueous phase concentrations are usually not predicted by models that exceed studies on a process level. AqSOA precursors (such as glyoxal, methylglyoxal, MVK, MACR) also have loss terms in the gas phase (oxidation, photolysis) that are suppressed in bulk laboratory experiments. In the atmosphere, the overall aqSOA yield, related to the gas phase con-

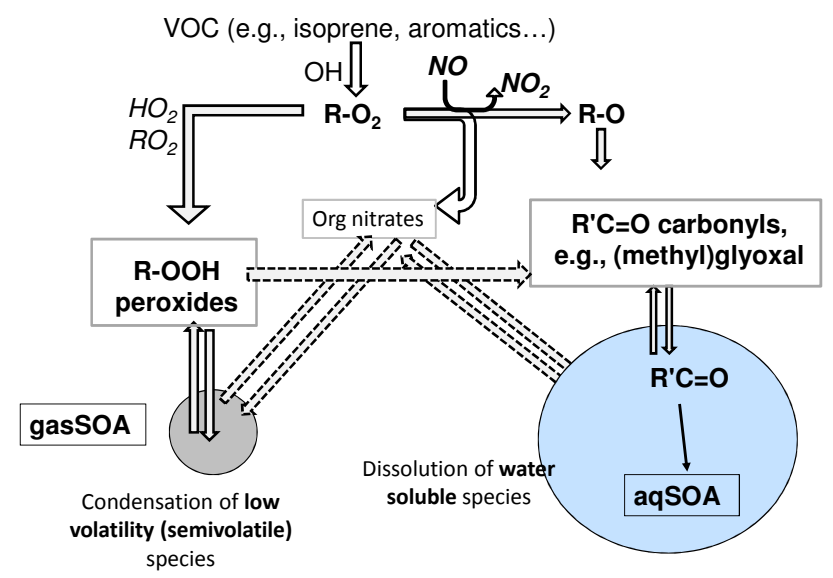

Fig. 5. Fate of peroxy radicals in the gas phase in different $\mathrm{NO}_{\mathrm{x}}$ scenarios. Dashed arrows depict slow pathways that might only occur on large (spatial, temporal) scales.

centration of a precursor, depends on the relative strength of gas phase loss terms and uptake and further processing in the aqueous phase. A more thorough assessment of the amount of aqSOA formed from specific precursors can only be obtained by simulating multiphase systems that take into account gas and aqueous phase processes simultaneously.

While low $\mathrm{NO}_{\mathrm{x}}$ levels often lead to higher production rates of low volatility compounds and gasSOA products, high $\mathrm{NO}_{\mathrm{x}}$ levels preferentially form high volatility, highly watersoluble species (Fig. 4). However, on larger (spatial, temporal) scales similar concentrations of carbonyl compounds (glyoxal, methylglyoxal) have been predicted under all $\mathrm{NO}_{\mathrm{x}}$ conditions since slow conversions of peroxides and organic nitrates might yield similar products (Fu et al., 2009). Thus, for aqSOA yields a clear separation into "high $\mathrm{NO}_{\mathrm{x}}$ " and "low $\mathrm{NO}_{\mathrm{x}}$ " conditions is not as obvious as it is for gasSOA and on large scales similar aqSOA yields in both scenarios can be expected. In summary, the time dependence of aqSOA reactions in the aqueous phase, and the time dependence of the $\mathrm{NO}_{\mathrm{x}}$ dependent formation of water-soluble aqSOA precursors to $\mathrm{NO}_{\mathrm{x}}$ concentrations make it difficult to compare aqSOA and gasSOA yields on a common basis. In addition, the partitioning of low-volatility or semivolatile species between gas, organic and aqueous phases depends on the abundance of the respective particulate phases. Despite these complex interactions, we will give in the following section some rough estimates of SOA yields and mass predictions from box model calculations using the data in Tables 1 and 2 (processes marked with ${ }^{*}$ ) in order to provide some guidance to identify conditions under which aqSOA formation is likely to be important. 


\subsubsection{Comparison of gasSOA and aqSOA yields}

Cloud aqSOA yields (mass of aqSOA per mass of isoprene reacted in the gas phase) from multiphase isoprene oxidation over several hours (i.e. relatively short time scales) have been parameterized as a function of $\mathrm{NO}_{\mathrm{x}}$ levels, cloud contact time and cloud LWC (Ervens et al., 2008). These yields ranged from 3-9\% for high $\mathrm{NO}_{\mathrm{x}}$ levels and $0.3-0.7 \%$ for low $\mathrm{NO}_{\mathrm{x}}$ levels. GasSOA yields show the opposite trends with $\mathrm{NO}_{\mathrm{x}}$ levels and range from 1-4\% (Kroll et al., 2005a; Henze and Seinfeld, 2006).

A similar approach has been taken here to compare aerosol aqSOA yields and gasSOA yields for various precursors: a box model has been initialized with a single precursor compound (benzene, toluene, xylene or isoprene) and a constant $\mathrm{OH}$ concentration of $10^{6} \mathrm{~cm}^{-3}$. GasSOA products comprise two products (P1, P2) according to the 2-product model. In addition to these condensable products, all of the selected precursors form glyoxal and methylglyoxal (except benzene) in the gas phase and eventually form aqSOA in the aqueous phase:

Precursor $+\mathrm{OH} \rightarrow \underbrace{\alpha 1 \mathrm{P} 1+\alpha 2 \mathrm{P} 2}_{\text {gasSOA }}+\underbrace{\text { glyoxal }+ \text { methylglyoxal }}_{\text {forming aqSOA }}$ (7)

GasSOA yields can be calculated based on the 2-product model or the VBS based on

$Y(\operatorname{gasSOA})=\sum_{i=n}\left[m(\operatorname{org}) \frac{\alpha_{i} K_{\mathrm{p}, i}}{\left(1+m(\operatorname{org}) \cdot K_{\mathrm{p}, i}\right)}\right]$

where $n$ is either 2 (2-product model) or represents the number of different volatility bins oxidation products are distributed to (VBS). $\mathrm{NO}_{\mathrm{x}}$ dependent glyoxal and methylglyoxal yields have been determined for aromatics and isoprene in (dry) smog chamber experiments (Spaulding et al., 2003; Nishino et al., 2010). Total glyoxal and methylglyoxal yields from isoprene are less constrained as these species are not only first-order but also second-order products that are formed from the major oxidation products MACR and MVK (Galloway et al., 2011a).

High- $\mathrm{NO}_{\mathrm{x}}$ smog chamber experiments of isoprene oxidation have shown that RH does not change the total SOA mass but significantly impacts the product distribution due to higher yields of glycolaldehyde and hydroxyacetone at high RH (Nguyen et al., 2011). In this study, no differences in methylglyoxal levels were detected and the impact on glyoxal was not evaluated. Under low $\mathrm{NO}_{\mathrm{x}}$ conditions, a decrease in SOA yields of a factor 2-3 under high RH was observed (H. Zhang et al., 2011). This trend is in agreement with the higher yields of carbonyl compounds under high $\mathrm{NO}_{\mathrm{x}}$ conditions that might result in more aqSOA formation. Aqueous phase chemistry is not directly dependent on $\mathrm{NO}$ and $\mathrm{NO}_{2}$ as they have low solubility and thus their role as aqueous phase oxidants is minor; the major influence of $\mathrm{NO}_{\mathrm{x}}$ on aqSOA yields lies in the preceding gas phase chemistry that determines the concentration levels of aqSOA precursors. In both studies, it was found that at high RH, contributions of organonitrates increased whereas at low RH, ester formation was predominant. A similar trend of SOA yields with RH was observed for SOA formation from $\alpha$ pinene; however, in this study, experiments were only performed at $2 \% \leq \mathrm{RH} \leq 50 \%$ (Cocker et al., 2001a). Parikh et al. (2011) inferred a significant contribution of aqSOA to total SOA from aromatics based on box model simulations of chamber experiments over a wide range of $\mathrm{RH}$ with highest SOA yields at high RH. These results seem at odds with earlier results of the same reaction system that did not find any effect of RH on SOA yields from aromatics (Cocker et al., 2001b); however, also in these studies the range of RH was limited $(\leq 50 \%)$ and thus the amount of aerosol water on the ammonium sulfate seed aerosol was minimal. The investigation of the temperature and RH dependence of the ozone reaction with $\beta$-pinene has shown that SOA yields decrease with temperature at dry conditions whereas they show the opposite behavior at elevated RH (von Hessberg et al., 2009). These trends can be explained with the fact that high temperatures favor evaporation of gasSOA from particles (i.e. less partitioning) and the acceleration of (aqueous) particle phase reaction that form aqSOA.

The box model applied here includes Eq. (7) for benzene, toluene, xylene, and isoprene as representative SOA precursors. For gasSOA yield predictions, the same module as in a previous SOA model study has been used (Bahreini et al., 2009); a multiphase mechanism as depicted in Eq. (7) was assumed for an aerosol population that consisted of $2 \mu \mathrm{g} \mathrm{m}^{-3}$ organic mass and $20 \mu \mathrm{g} \mathrm{m}^{-3}$ aerosol water. The dependence of gas phase carbonyl yields on $\mathrm{NO}_{\mathrm{x}}$ levels are reflected in the trends of aqSOA yields with higher yields at high $\mathrm{NO}_{\mathrm{x}}$, in contrast to gasSOA yields (Fig. 5). However, it should be cautioned here again, that the carbonyl yields are based on chamber experiments over relatively short time scales that might not capture the conversion of "low $\mathrm{NO}_{\mathrm{x}}$ products" into carbonyl compounds (Fig. 5). The results in Fig. 6 show that benzene likely does not form high amounts of aqSOA under the assumed conditions. The data for aqSOA formation from phenol is not included in the current estimate even though in laboratory experiments it has been observed that ring-retaining products from aqueous phase phenol oxidation might form additional aqSOA (Sun et al., 2010) (Sect. 2.1.2). For toluene and xylene, methylglyoxal yields are higher than those for glyoxal; however, the Henry's law constant of methylglyoxal is much smaller than that of glyoxal and thus its transport into the aqueous particles is slower resulting in smaller aqSOA yields. Thus, the overall aqSOA yields from toluene and xylene are mostly from glyoxal (aqSOA yield at low $\mathrm{NO}_{\mathrm{x}} 1.9 \%, 3.5 \%$; aqSOA yield at high $\mathrm{NO}_{\mathrm{x}}: 2.3 \%, 2.3 \%$ ).

The aqSOA yields from isoprene are comparable to gasSOA yields for the conditions chosen here. Direct contributions of MVK and MACR to aqSOA are not included in the current model approach. These latter products are not 


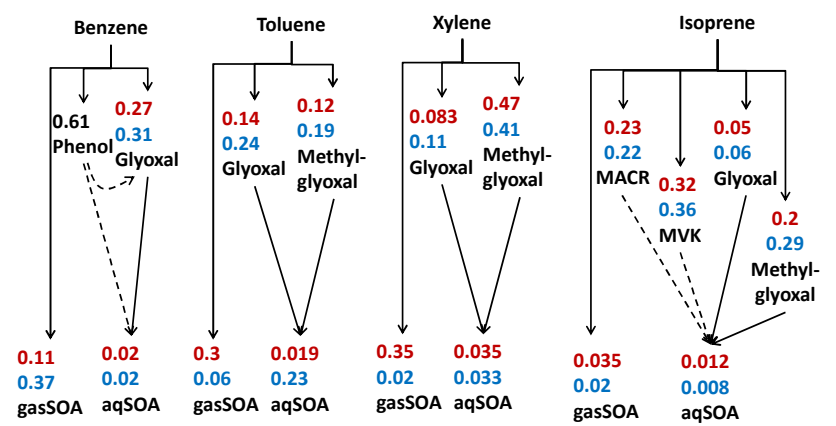

Fig. 6. Comparison of gasSOA and aqSOA yields from various precursors in the presence of $[\mathrm{OH}]=10^{6} \mathrm{~cm}^{-3}$ over $12 \mathrm{~h}$. GasSOA yields are based on smog chamber experiments under low (red)/high (blue) $\mathrm{NO}_{\mathrm{x}}$ conditions and are calculated for an assumed organic aerosol mass of $10 \mathrm{\mu g} \mathrm{m}^{-3}$. AqSOA yields are derived from box model studies using kinetic data (Tables 1 and 2, data with ${ }^{*}$ ) and are derived for $20 \mathrm{\mu g} \mathrm{m}^{-3}$ aerosol water.

very water-soluble but have shown to form aqSOA once dissolved (El Haddad et al., 2009; Noziere et al., 2010b; Zhang et al., 2010). Their vapor pressure is also reasonably low that they might form gasSOA and thus are partially captured by P1 and P2 (Eq. 8). It should be noted that in case of efficient removal of MACR and MVK by the aqueous phase, gasSOA yields as derived from (dry) smog chamber experiments might be smaller and the numbers in Fig. 6 might represent an overestimate for gasSOA. This overlap in low volatility and water-solubility makes it difficult to derive accurate yields. The trends in our yield predictions follow those from a previous model study where significant aqSOA formation from isoprene was predicted (Couvidat and Seigneur, 2011). However, both this latter study and our study assume identical partitioning parameters $\left(\alpha_{i}, K_{\mathrm{p}, i}\right)$ for isoprene under high and low RH conditions although recent chamber experiments suggest that at high $\mathrm{RH}$ aqSOA formation might play a role and this cannot be fully parameterized by Eq. (8) (Nguyen et al., 2011).

\subsubsection{Comparison of gasSOA and aqSOA mass predictions}

The comparison of gasSOA and aqSOA yields provided here describes the relative propensity of a compound to form gasSOA versus aqSOA. However, the absolute importance of gasSOA versus aqSOA pathways to the total SOA budget depends also on the availability of liquid water and the relative availability of the various precursors. In Table 3, four sets of conditions are summarized representing a wide range of biogenic/anthropogenic concentrations, and dry/humid scenarios. These conditions represent averages of observations even though they do not reflect the variability as observed in these regions. We do not attempt to predict the exact observed SOA masses in these regions as the simplicity of a box model does not allow the simulation of dynamic (e.g. transport, mixing, dilution) and detailed chemical processes (e.g. photochemistry). We rather use the input data in Table 3 to compare gasSOA versus aqSOA formation in the context of different volatile organic compounds (VOC) and RH conditions.

Figure 7 shows the predicted gasSOA and aqSOA masses for the four cases specified in Table 3 . We show gasSOA predictions for both the 2-product model and the VBS; in agreement with other studies, VBS gives higher gasSOA predictions as also semivolatile compounds are taken into account. In anthropogenic influenced areas at high $\mathrm{RH}$ (scenarios I and III), the contribution of aqSOA to the total predicted SOA mass is about $30-50 \%$ despite the relatively high glyoxal and methylglyoxal yields from aromatics. In the biogenically-dominated scenario (II) SOA formation from gas and aqueous phase pathways are roughly equally important. The opposite trend of carbonyl (glyoxal, methylglyoxal, hydroxyacetone, glycoladehyde) and gasSOA yields could have a significant impact on SOA predictions. Whereas under high $\mathrm{NO}_{\mathrm{x}}$ conditions the gasSOA yields from isoprene are small, the importance of aqSOA increases. Several studies have pointed to the role of anthropogenic compounds $\left(\mathrm{NO}_{\mathrm{x}}\right)$ in oxidation of biogenic carbon emissions that lead to SOA formation (Weber et al., 2007; Carlton et al., 2010; Spracklen et al., 2011). However, such interactions are underestimated by current gasSOA approaches. At very low RH (scenario IV), none of the chosen precursors will significantly contribute to aqSOA formation due to the negligible amount of aerosol water. This latter result is in agreement with a model study in Houston, TX, where reasonable agreement between predicted and observed (airborne) SOA masses where obtained based on gasSOA yields (Bahreini et al., 2009; Zhang and Ying, 2011). In summary, Fig. 7 highlights the sensitivities of selected regions for aqSOA formation that should be explored in more detail in future studies. These studies suggest that aqSOA formation will be most important in humid regions that are influenced by biogenic emissions.

\section{Outlook: knowledge gaps and needed research}

\subsection{Laboratory studies of aqueous and multiphase processes}

Aqueous phase experiments in highly concentrated organic and inorganic aqueous solutions have provided a relatively well-constrained set of kinetic data and chemical mechanisms for $\mathrm{OH}$ radical oxidation and other processes of carbonyl compounds in dilute and concentrated solutions (cloud- and aerosol water-like, respectively). However, several mysteries remain which affect the accuracy of aqSOA model prediction. Several studies suggest that the partitioning of glyoxal and methylglyoxal (and likely related 
Table 3. Initial conditions for box model studies to evaluate gasSOA and aqSOA mass formation, Eq. (7). Model results are presented in Fig. 7.

\begin{tabular}{|c|c|c|c|c|c|c|c|}
\hline & $\begin{array}{l}\mathrm{RH} \\
{[\%]}\end{array}$ & $\begin{array}{l}\text { Dry mass } \\
{\left[\mu \mathrm{g} \mathrm{m}^{-3}\right]}\end{array}$ & $\begin{array}{l}\text { Organic } \\
\text { fraction }\end{array}$ & $\begin{array}{r}\text { Benzene } \\
\text { [ppb] }\end{array}$ & $\begin{array}{r}\text { Toluene } \\
\text { [ppb] }\end{array}$ & $\begin{array}{r}\text { Isoprene } \\
{[\mathrm{ppb}]}\end{array}$ & $\begin{array}{l}\text { Region typical } \\
\text { for air mass }\end{array}$ \\
\hline I & 70 & 24 & 0.4 & 1 & 3 & 0 & Los Angeles (Hersey et al., 2011) \\
\hline II & 90 & 1 & 0.75 & 0 & 0 & 2 & Amazon (Martin et al., 2010) \\
\hline III & 80 & 15 & 0.5 & 0.6 & 3 & 0 & Po Valley (Steinbacher et al., 2005; Carbone et al., 2010) \\
\hline IV & 45 & 15 & 0.67 & 0.2 & 0.3 & 0.4 & Houston, TX (Bahreini et al., 2009) \\
\hline
\end{tabular}
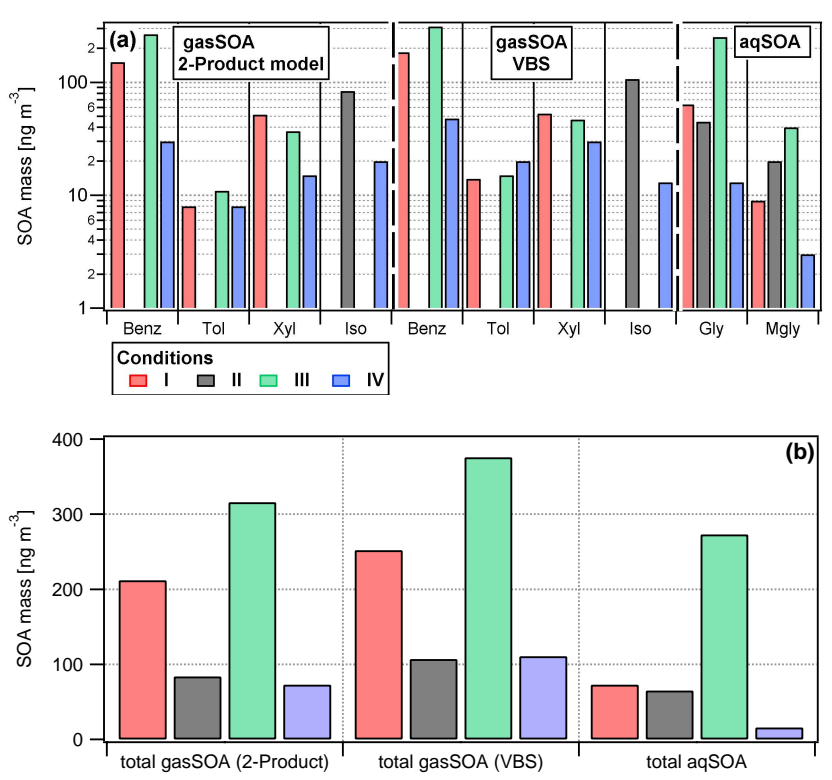

Fig. 7. Comparison of predicted gasSOA and aqSOA masses from various precursors in the presence of $[\mathrm{OH}]=10^{6} \mathrm{~cm}^{-3}$ over $12 \mathrm{~h}$ for the conditions as specified in Table 3 .

compounds) into aqueous seed aerosol is much higher than in pure water. This increased uptake was assumed to be related to oligomerization which is associated with relatively long time scales until equilibrium is reached; however, the dependence of different seed aerosol compositions on observed $K_{\mathrm{H}} *$ and kinetic data in seed aerosols could not be explained (Ervens and Volkamer, 2010). A recent study suggests that the shift of glyoxal partitioning towards the particle phase is due to a stabilization of the glyoxal dihydrate (Yu et al., 2011). Another study has identified a strong dependence of the reaction rates of glyoxal on the chemical composition of the aerosol seed under dark and photochemical conditions (Galloway et al., 2011b). However, these effects are only described qualitatively and await a better quantification and numerical description to be implemented in models. Similar to enhanced partitioning of organics, several studies point to enhanced levels of reactive oxygen species in particles (Hasson and Paulson, 2003; Arellanes et al., 2006; Shen et al.,
2011). The reason for these deviations from thermodynamic equilibrium $\left(K_{\mathrm{H}}\right)$ is not clear and related modeling assumptions of oxidant transport into and within aerosol particles and the resulting oxidant levels are a significant source of uncertainty in aqSOA prediction.

Water-soluble organic and inorganic compounds might form separate phases within an aerosol particle (Zuend et al., 2008; Bertram et al., 2011; Zuend et al., 2011). Such effects will affect the availability of reactants of inorganic/organic cross-reactions that lead to organosulfates or organo-nitrogen compounds. It seems unfeasible for the near future to develop and implement detailed thermodynamic models that take such effects into account. However, laboratory experiments should be designed to examine the extent to which such phase separation indeed occurs and affects aqSOA formation rates.

Most laboratory experiments are designed as homogeneous aqueous phase experiments and thus observed aqSOA formation are interpreted as bulk reaction parameters. Some multiphase experiments that investigate the uptake and further processing of aqSOA precursors into aqueous aerosols, have shown evidence that aqSOA formation could also occur at the gas/particle interface (Ervens and Volkamer, 2010; Grgic et al., 2010; D. Huang et al., 2011). Size-resolved measurements of processed aerosol distributions will give evidence of the importance of either type of process since the relative contributions of bulk versus surface aqSOA formation will determine the size distribution of the predicted SOA. In general, there is a lack of experiments of SOA formation at $\mathrm{RH}$ above the deliquescence RH or even above the $\mathrm{CCN}$ activation threshold (droplet formation) of seed aerosol. Thus, aerosol and cloud chambers that allow the characterization of the chemical multiphase system are a promising tool to elucidate further details of aqSOA formation (e.g. J. Wang et al., 2011).

\subsection{Identification of additional aqSOA precursors}

While our discussion of aqSOA formation is mostly focused on glyoxal and methylglyoxal, other small compounds undergo similar processes (e.g. glycolaldehyde, pyruvic acid, other small acids, peroxides, and alcohols). While in 
laboratory studies it has been shown that such compounds can indeed form HMWC, it is likely that also other highly functionalized compounds with longer carbon chains $\left(>\mathrm{C}_{3}\right)$ are taken up into cloud or aerosol water and become processed to form HMWC or acids. While the contributions of larger dicarboxylic acids in cloud water are small as compared to the total OC masses, the contributions of their oligomers in aerosols might be considerable.

\subsection{Role of parameters that affect gas phase chemistry: $\mathrm{RH}$ and $\mathrm{NO}_{\mathrm{x}}$}

Most smog chamber experiments are performed under (nearly) dry conditions and thus yields of gas phase products of SOA precursors are usually reported for those conditions. However, as shown in a recent experiment, the amount of water vapor can affect the product distribution from isoprene oxidation (Nguyen et al., 2011). While coincidentally the SOA yields under high and low RH were the same in these experiments, the product distribution is different which will have impact on the properties of SOA mass (solubility, optical properties etc). The few available studies that address the role of $\mathrm{NO}_{\mathrm{x}}$ on SOA formation under high $\mathrm{RH}$ suggest the formation of aqSOA (Nguyen et al., 2011; H. Zhang et al., 2011). However, more systematic studies are needed to identify the product distributions from a greater variety of precursors in order to refine both the gasSOA parameters $(\alpha$, $K_{\mathrm{p}}$ ) and aqSOA yields for atmospherically-relevant ranges of $\mathrm{RH}$ and $\mathrm{NO}_{\mathrm{x}}$ levels.

\subsection{Identification of tracers of ambient aqSOA}

While oxalate is a good tracer for aqSOA formation, its formation rate in aerosol water might be small due to the preference of accretion reactions. Organosulfur compounds e.g. organosulfates, hydroxymethane sulfonate have been identified in ambient samples (Dixon and Aasen, 1999; Froyd et al., 2010; Schmitt-Kopplin et al., 2010; Hatch et al., 2011; Kristensen and Glasius, 2011; Olson et al., 2011). These compounds only comprise a small fraction of total OC; however, their formation pathways are unique to the aqueous phase and thus point to aqSOA formation. It is likely that specific HMWC, patterns of HMWC or subunits that add multiple times to HMWC, identified in rain or fog water (Altieri et al., 2009; Mazzoleni et al., 2010), can be used to deduce the aqueous processing of aerosol particles. One value in identifying such tracers is that they could potentially be used to estimate aqSOA contributions via receptor modeling techniques. Their concentration levels should be used to challenge the current knowledge of underlying formation mechanisms using detailed process aqSOA models. Another potential of such tracer compounds together with the kinetic information in Tables 1 and 2, is to test our understanding of aqSOA sources, like oxalate prediction was used simulate aqSOA formation in a recent global model (Myriokefalitakis et al., 2011). Such work would benefit from the measurement of aqSOA tracers in regions where aqSOA formation is likely, such as in regions of cloud outflow or forested humid regions.

As discussed in Sect. 3.2, aqSOA formation modifies aerosol size distributions in a different way than gasSOA condensation with pronounced mass addition to the droplet mode. Thus, size-resolved, instead of only bulk, OA measurements (e.g. AMS spectra) should be able to provide insights into SOA formation pathways. AqSOA products have in general low volatility and thus might significantly contribute to "low volatility oxygenated organic aerosol (LVOOA)". Specific compounds, such as oxalate, even exceed the range of carbon oxidation state and $\mathrm{O} / \mathrm{C}$ ratio as covered by LV-OOA (Kroll et al., 2011). AMS data are often characterized by means of positive matrix factorization (PMF) which identifies types of aerosol based on similarities in spectra (Ulbrich et al., 2009); available spectra in scenarios where aqSOA formation can be expected should be revisited to identify features that might point to aqSOA formation.

\subsection{Evaluation of gasSOA versus aqSOA formation in more comprehensive models}

The time scales of gasSOA versus aqSOA formation in different scenarios could be compared by using the framework by Kerminen and Wexler (1995) that provides general equations for aqueous phase and condensation processes as a function of ambient parameters. Such a comparison can be used to evaluate the relative importance of such processes and to identify areas and conditions for which either SOA source might be important.

Several models have included cloud aqSOA formation and have compared its efficiency to gasSOA formation; however, the implementation of the full, detailed chemistry as listed in Tables 1 and 2 represents a major computational burden and thus simpler expressions are needed. Whereas first attempts have been made to parameterize cloud aqSOA yields from isoprene (Ervens et al., 2008), this expression cannot be used to simulate aqSOA in anthropogenic scenarios or in aerosol water. Thus, a more general expression for water-soluble, direct aqSOA precursors (e.g. glyoxal, methylglyoxal) would be desirable.

The reason for the lack of comprehensive model studies of aerosol aqSOA formation is the missing comprehensive data sets for the underlying chemical processes. The parameters in Tables 1 and 2 provide such data sets and can be used in process models. Upon such model simulations, appropriate and simple expressions can be developed for use in large scale models. Thus, in terms of model applications, the development of simple but robust expressions that parameterize the formation of aerosol aqSOA is sorely needed. These expressions should be carefully tested against laboratory measurements and models that allow well-constrained detailed chemistry modules, i.e. in box or parcel models that 
are restricted in terms of microphysical/dynamic processes but are able to include many chemical species and processes.

\section{Summary and conclusions}

The current review summarizes evidence that secondary organic aerosol forms in the aqueous phase of cloud/fog/rain droplets as was postulated about a decade ago (Blando and Turpin, 2000). While the former "plausibility study" focused mostly on processes in dilute aqueous phase (droplets), many recent laboratory experiments and ambient aerosol samples suggest that more complex chemical reactions can occur in aerosol water forming accretion products such as oligomers, (e.g. Volkamer et al., 2007, 2009; Tan et al., 2011). Kinetic data from such laboratory experiments for photochemical and dark reactions are summarized. Model results using this data that compare aqSOA formation in cloud and aerosol water suggest that over identical time scales both sources are comparably important. Considering that individual cloud droplets only exist for several minutes whereas water-containing aerosol particles reside in the atmosphere over hours or days might suggest a more significant role for aerosol aqSOA formation. Comparisons of aqSOA formation in aerosol water to gasSOA formation suggest that aqSOA formation contributes substantially to the total SOA mass, in particular in regions of high $\mathrm{RH}$, biogenic influence and high $\mathrm{NO}_{\mathrm{x}}$ conditions. However, explorative box model calculations performed here are very restricted in their large scale predictability.

Major uncertainties in current aqSOA estimates are identified and suggestions are made for further laboratory experiments and model development activities. We also identify a need for aqSOA tracer compounds to be used for receptor models in order to test our understanding of the chemical processes summarized based on laboratory studies. It can be expected that aqSOA will gain in importance in future climate as elevated temperature increase biogenic emissions and possibly RH (Hennigan et al., 2008c; Slowik et al., 2010; Day and Pandis, 2011; Hoyle et al., 2011), i.e. two factors that enhance carbonyl yields and thus aqSOA formation.

Acknowledgements. We thank Alma Hodzic and Jerome Fast for providing data for Fig. 2d, and 2e; we thank Jose Jimenez for useful discussions. BE acknowledges support from NOAA's Climate Goal and from the Office of Science (BER), US Department of Energy, grant DE-FG02-08ER64539. BT acknowledges support from NOAA (NA07OAR4310279) and the EPA STAR program (WDC-RD-833751).

Edited by: J. H. Seinfeld

\section{References}

Aiken, A. C., Decarlo, P. F., Kroll, J. H., Worsnop, D. R., Huffman, J. A., Docherty, K. S., Ulbrich, I. M., Mohr, C., Kimmel, J. R., Sueper, D., Sun, Y., Zhang, Q., Trimborn, A., Northway, M., Ziemann, P. J., Canagaratna, M. R., Onasch, T. B., Alfarra, M. R., Prevot, A. S. H., Dommen, J., Duplissy, J., Metzger, A., Baltensperger, U., and Jimenez, J. L.: O/C and OM/OC ratios of primary, secondary and ambient organic aerosols with highresolution time-of-flight aerosol mass spectrometry, Environ. Sci Technol., 42, 12, 4478-4485, 2008.

Altieri, K., Carlton, A. G., Lim, H., Turpin, B. J., and Seitzinger, S. P.: Evidence for oligomer formation in clouds: Reaction of isoprene oxidation products, Environ. Sci. Technol., 40,4956-4960, 2006.

Altieri, K. E., Seitzinger, S. P., Carlton, A. G., Turpin, B. J., Klein, G. C., and Marshall, A. G.: Oligomers formed through in-cloud methylglyoxal reactions: Chemical composition, properties, and mechanisms investigated by ultra-high resolution FT-ICR mass spectrometry, Atmos. Environ., 42,1476-1490, 2008.

Altieri, K. E., Turpin, B. J., and Seitzinger, S. P.: Oligomers, organosulfates, and nitrooxy organosulfates in rainwater identified by ultra-high resolution electrospray ionization FTICR mass spectrometry, Atmos. Chem. Phys., 9, 2533-2542, doi:10.5194/acp-9-2533-2009, 2009.

Anastasio, C., Faust, B. C., and Rao, C. J.: Aromatic Carbonyl Compounds as Aqueous Phase Photochemical Sources of Hydrogen Peroxide in Acidic Sulfate Aerosols, Fogs, and Clouds. 1. Non-Phenolic Methoxybenzaldehydes and Methoxyacetophenones with Reductants (Phenols), Environ. Sci. Technol., 31, 218-232, 1997.

Arakaki, T. and Faust, B. C.: Sources, sinks and mechanisms of hydroxyl radical $(\mathrm{OH})$ photoproduction and consumption in authentic acidic continental cloud waters from Whiteface mountain, New York: The role of the $\mathrm{Fe}(r)(r=\mathrm{II}, \mathrm{III})$ photochemical cycle, J. Geophys. Res., 103, 3487-3504, 1998.

Arellanes, C., Paulson, S. E., Fine, P. M., and Sioutas, C.: Exceeding of Henry's Law by Hydrogen Peroxide Associated with Urban Aerosols, Environ. Sci. Technol., 40, 4859-4866, doi:10.1021/es0513786, 2006.

Baboukas, E. D., Kanakidou, M., and Mihalopoulos, N.: Carboxylic acids in gas and particulate phase above the Atlantic Ocean, J. Geophys. Res., 105,14459-14471, 2000.

Bahreini, R., Ervens, B., Middlebrook, A. M., Warneke, C., DeGouw, J. A., DeCarlo, P., Jimenez, J. L., Brock, C. A., Neuman, J. A., Ryerson, T. B., Stark, H., Atlas, E., Brioude, J., Fried, A., Holloway, J. S., Peischl, J., Richter, D., Walega, J., Weibring, P., Wollny, A. G., and Fehsenfeld, F. C.: Organic aerosol formation in urban and industrial plumes in Houston, TX, J. Geophys. Res., 114, D00F16, doi:10.1029/2008JD011493, 2009.

Barsanti, K. C. and Pankow, J. F.: Thermodynamics of the formation of atmospheric organic particulate matter by accretion reactions - Part 1: aldehydes and ketones, Atmos. Environ, 38, 43714382, 2004.

Barsanti, K. C. and Pankow, J. F.: Thermodynamics of the formation of atmospheric organic particulate matter by accretion reactions - Part 2: Dialdehydes, methylglyoxal, and diketones, Atmos. Environ., 39, 6597-6607, 2005.

Bateman, A. P., Nizkorodov, S. A., Laskin, J., and Laskin, A.: Photolytic processing of secondary organic aerosols dissolved 
in cloud droplets, Phys. Chem. Chem. Phys., 13, 12199-12212, 2011.

Bertram, A. K., Martin, S. T., Hanna, S. J., Smith, M. L., Bodsworth, A., Chen, Q., Kuwata, M., Liu, A., You, Y., and Zorn, S. R.: Predicting the relative humidities of liquid-liquid phase separation, efflorescence, and deliquescence of mixed particles of ammonium sulfate, organic material, and water using the organic-to-sulfate mass ratio of the particle and the oxygen-tocarbon elemental ratio of the organic component, Atmos. Chem. Phys., 11, 10995-11006, doi:10.5194/acp-11-10995-2011, 2011.

Blando, J. D. and Turpin, B. J.: Secondary organic aerosol formation in cloud and fog droplets: a literature evaluation of plausibilty, Atmos. Environ., 34, 1623-1632, 2000.

Blando, J. D., Porcja, R. J., Li, T., Bowman, D., Lioy, P. J., and Turpin, B. J.: Secondary Formation and the Smoky Mountain Organic Aerosol: An Examination of Aerosol Polarity and Functional Group Composition During SEAVS, Environ. Sci. Technol, 32, 604-613, 1998.

Buxton, G. V., Malone, T. N., and Salmon, G. A.: Oxidation of glyoxal initiated by $\mathrm{OH}$ in oxygenated aqueous solutions, J. Chem. Soc. Faraday Trans., 93, 2889-2891, 1997.

Cappa, C., Che, D., Kessler, S., Kroll, J., and Wilson, K.: Variations in organic aerosol optical and hygroscopic properties upon heterogeneous OH oxidation, J. Geophys. Res., 116, D15204, doi:10.1029/2011jd015918, 2011.

Carbone, C., Decesari, S., Mircea, M., Giulianelli, L., Finessi, E., Rinaldi, M., Fuzzi, S., Marinoni, A., Duchi, R., Perrino, C., Sargolini, T., Vardè, M., Sprovieri, F., Gobbi, G. P., Angelini, F., and Facchini, M. C.: Size-resolved aerosol chemical composition over the Italian Peninsula during typical summer and winter conditions, Atmos. Environ., 44, 5269-5278, doi:10.1016/j.atmosenv.2010.08.008, 2010.

Carlton, A. G., Turpin, B. J., Lim, H., Altieri, K. E., and Seitzinger, S.: Link between isoprene and secondary organic aerosol (SOA): Pyruvic acid oxidation yields low volatility organic acid in clouds, Geophys. Res. Lett., 33, 06822, doi:10.1029/2005GL025374, 2006.

Carlton, A. G., Turpin, B. J., Altieri, K. E., Reff, A., Seitzinger, S., Lim, H., and Ervens, B.: Atmospheric oxalic acid and SOA production from glyoxal: Results of aqueous photooxidation experiments, Atmos. Environ., 41, 7588-7602, 2007.

Carlton, A. G., Turpin, B. J., Altieri, K. E., Seitzinger, S. P., Mathur, R., Roselle, S. J., and Weber, R. J.: CMAQ Model Performance Enhanced When In-Cloud Secondary Organic Aerosol is Included: Comparisons of Organic Carbon Predictions with Measurements, Environ. Sci. Technol., 42, 8789-8802, 2008.

Carlton, A. G., Pinder, R. W., Bhave, P. V., and Pouliot, G. A.: To What Extent Can Biogenic SOA be Controlled?, Environ. Sci. Technol., 44, 3376-3380, doi:10.1021/es903506b, 2010.

Casale, M. T., Richman, A. R., Elrod, M. J., Garland, R. M., Beaver, M. R., and Tolbert, M. A.: Kinetics of acid-catalyzed aldol condensation reactions of aliphatic aldehydes, Atmos. Environ., 41, 6212-6224, 2007.

Chang, J. L. and Thompson, J. E.: Characterization of colored products formed during irradiation of aqueous solutions containing $\mathrm{H}_{2} \mathrm{O}_{2}$ and phenolic compounds, Atmos. Environ., 44, 541-551, doi:10.1016/j.atmosenv.2009.10.042, 2010.

Chang, W. L., Griffin, R. J., and Dabdub, D.: Partitioning phase preference for secondary organic aerosol in an urban atmosphere, P. Natl. Acad. Sci., 107, 6705-6710, doi:10.1073/pnas.0911244107, 2010.

Chen, J., Griffin, R. J., Grini, A., and Tulet, P.: Modeling secondary organic aerosol formation through cloud processing of organic compounds, Atmos. Chem. Phys., 7, 5343-5355, doi:10.5194/acp-7-5343-2007, 2007.

Chen, Z. M., Wang, H. L., Zhu, L. H., Wang, C. X., Jie, C. Y., and Hua, W.: Aqueous-phase ozonolysis of methacrolein and methyl vinyl ketone: a potentially important source of atmospheric aqueous oxidants, Atmos. Chem. Phys., 8, 2255-2265, doi:10.5194/acp-8-2255-2008, 2008.

Cocker III, D. R., Clegg, S. L., Flagan, R. L., and Seinfeld, J. H.: The effect of water on gas-particle partitioning of secondary organic aerosol. Part I: a-pinene/ozone system, Atmos. Environ., 35, 6049-6072, 2001a.

Cocker III, D. R., Mader, B. T., Kalberer, M., Flagan, R. L., and Seinfeld, J. H.: The effect of water on gas-particle partitioning of secondary organic aerosol. Part II: m-xylene and 1,3,5trimethyl benzene photoxidation systems, Atmos. Environ., 35, 6073-6085, 2001b.

Compernolle, S., Ceulemans, K., and Müller, J.-F.: EVAPORATION: a new vapour pressure estimation methodfor organic molecules including non-additivity and intramolecular interactions, Atmos. Chem. Phys., 11, 9431-9450, doi:10.5194/acp-119431-2011, 2011.

Couvidat, F. and Seigneur, C.: Modeling secondary organic aerosol formation from isoprene oxidation under dry and humid conditions, Atmos. Chem. Phys., 11, 893-909, doi:10.5194/acp-11893-2011, 2011.

Crahan, K. K., Hegg, D., Covert, D. S., and Jonsson, H.: An exploration of aqueous oxalic acid production in the coastal marine atmosphere, Atmos. Environ., 38, 3757-3764, 2004.

Creighton, D. J., Migliorini, M., Pourmotabbed, T., and Guha, M. K.: Optimization of efficieny in the glyoxylase pathway, Biochem., 27, 7376-7384, 1988.

Day, M. C. and Pandis, S. N.: Predicted changes in summertime organic aerosol concentrations due to increased temperatures, Atmos. Environ., 45, 6546-6556, doi:10.1016/j.atmosenv.2011.08.028, 2011.

De Haan, D. O., Corrigan, A. L., Smith, K. W., Stroik, D. R., Turley, J. J., Lee, F. E., Tolbert, M. A., Jimenez, J. L., Cordova, K. E., and Ferrell, G. R.: Secondary organic aerosol-forming reactions of glyoxal with amino acids, Environ. Sci. Technol., 43, 28182824, 2009a.

De Haan, D. O., Corrigan, A. L., Tolbert, M. A., Jimenez, J. L., Wood, S. E., and Turley, J. J.: Secondary Organic Aerosol Formation by Self-Reactions of Methylglyoxal and Glyoxal in Evaporating Droplets, Environ. Sci Technol., 43, 8184-8190, doi:10.1021/es902152t, 2009b.

De Haan, D. O., Tolbert, M. A., and Jimenez, J. L.: Atmospheric condensed phase reactions of glyoxal with methylamine, Geophys. Res. Lett., 36, L11819, doi:10.1029/2009GL037441, 2009c.

De Haan, D. O., Hawkins, L. N., Kononenko, J. A., Turley, J. J., Corrigan, A. L., Tolbert, M. A., and Jimenez, J. L.: Formation of Nitrogen-Containing Oligomers by Methylglyoxal and Amines in Simulated Evaporating Cloud Droplets, Environ. Sci. Tech., 45, 984-991, doi:10.1021/es102933x, 2010.

Debus, H.: Über die Einwirkung des Ammoniaks auf Gly- 
oxal, Annalen der Chemie und Pharmacie, 107, 199-208, doi:10.1002/jlac.18581070209, 1858.

DeGouw, J. A., Middlebrook, A. M., Warneke, C., Goldan, P. D., Kuster, W. C., Roberts, J. M., Fehsenfeld, F. C., Worsnop, D. R., Canagaratna, M. R., Pszenny, A. A. P., Keene, W. C., Marchewka, M., Bertram, S. B., and Bates, T. S.: Budget of organic carbon in a polluted atmosphere: Results from the New England Air Quality Study in 2002, J. Geophys. Res., 110, D16305, doi:10.1029/2004JD005623, 2005.

Dixon, R. W. and Aasen, H.: Measurement of hydroxymethanesulfonate in atmospheric aerosols, Atmos. Environ., 33, 2023-2029, 1999.

Donahue, N. M., Robinson, A. L., Stanier, C. O., and Pandis, S. N.: Coupled partitioning, dilution and chemical aging of semivolatile organics, Environ. Sci. Technol., 40, 2635-2643, 2006.

Edney, E. O., Kleindienst, T. E., Jaoui, M., Lewandowski, M., Offenberg, J. H., Wang, W., and Claeys, M.: Formation of 2-methyl tetrols and 2-methylglyceric acid in secondary organic aerosol from laboratory irradiated isoprene/ $/ \mathrm{NO}_{\mathrm{x}} / \mathrm{SO}_{2} /$ air mixtures and their detection in ambient $\mathrm{PM}_{2.5}$ samples collected in the eastern United States, Atmos. Environ., 39, 5281-5289, 2005.

El Haddad, I., Yao Liu, Nieto-Gligorovski, L., Michaud, V., Temime-Roussel, B., Quivet, E., Marchand, N., Sellegri, K., and Monod, A.: In-cloud processes of methacrolein under simulated conditions - Part 2: Formation of secondary organic aerosol, Atmos. Chem. Phys., 9, 5107-5117, doi:10.5194/acp-9-5107-2009, 2009.

Ervens, B. and Volkamer, R.: Glyoxal processing by aerosol multiphase chemistry: towards a kinetic modeling framework of secondary organic aerosol formation in aqueous particles, Atmos. Chem. Phys., 10, 8219-8244, doi:10.5194/acp-10-8219-2010, 2010.

Ervens, B., George, C., Williams, J. E., Buxton, G. V., Salmon, G. A., Bydder, M., Wilkinson, F., Dentener, F., Mirabel, P., Wolke, R., and Herrmann, H.: CAPRAM2.4 (MODAC mechanism): An extended and condensed tropospheric aqueous phase mechanism and its application, J. Geophys. Res., 108, 4426, doi:10.1029/2002JD002202, 2003a.

Ervens, B., Gligorovski, S., and Herrmann, H.: Temperature dependent rate constants for hydroxyl radical reactions with organic compounds in aqueous solution, Phys. Chem. Chem. Phys., 5, 1811-1824, 2003b.

Ervens, B., Feingold, G., Frost, G. J., and Kreidenweis, S. M.: A modeling study of aqueous production of dicarboxylic acids, 1 . Chemical pathways and speciated organic mass production, J. Geophys. Res., 109, D15205, doi:10.1029/2003JD004387, 2004.

Ervens, B., Feingold, G., and Kreidenweis, S. M.: The influence of water-soluble organic carbon on cloud drop number concentration, J. Geophys. Res., 110, D18211, doi:10.1029/2004JD005634, 2005.

Ervens, B. and Kreidenweis, S. M.: SOA formation by biogenic and carbonyl compounds: Data evaluation and application, Environ. Sci. Technol., 41, 3904-3910, 2007.

Ervens, B., Carlton, A. G., Turpin, B. J., Altieri, K. E., Kreidenweis, S. M., and Feingold, G.: Secondary organic aerosol yields from cloud-processing of isoprene oxidation products, Geophys. Res. Lett., 35, L02816, doi:10.1029/2007gl031828, 2008.

Ervens, B., Cubison, M. J., Andrews, E., Feingold, G., Ogren, J. A., Jimenez, J. L., Quinn, P. K., Bates, T. S., Wang, J., Zhang,
Q., Coe, H., Flynn, M., and Allan, J. D.: CCN predictions using simplified assumptions of organic aerosol composition and mixing state: a synthesis from six different locations, Atmos. Chem. Phys., 10, 4795-4807, doi:10.5194/acp-10-4795-2010, 2010.

Fast, J. D., de Foy, B., Acevedo Rosas, F., Caetano, E., Carmichael, G., Emmons, L., McKenna, D., Mena, M., Skamarock, W., Tie, X., Coulter, R. L., Barnard, J. C., Wiedinmyer, C., and Madronich, S.: A meteorological overview of the MILAGRO field campaigns, Atmos. Chem. Phys., 7, 2233-2257, doi:10.5194/acp-7-2233-2007, 2007.

Favez, O., Sciare, J., Cachier, H., Alfaro, S. C., and Abdelwahab, M. M.: Significant formation of water-insoluble secondary organic aerosols in semi-arid urban environment, Geophys. Res. Lett., 35, L15801, doi:10.1029/2008g1034446, 2008.

Feingold, G.: Modeling of the first indirect effect: Analysis of measurement requirements, Geophys. Res. Lett., 30, 1997, doi:10.1029/2003GL017967, 2003.

Feingold, G. and Kreidenweis, S.: Does cloud processing of aerosol enhance droplet concentrations?, J. Geophys. Res., 105, 24351$24361,2000$.

Fillo, J. D., Koehler, C. A., Nguyen, T. P., DeHaan, D. O., Gilbert, B. A., and Flinn, K. P.: Simulating Secondary Organic Aerosol Activation by Condensation of Multiple Organics on Seed Particles, Environ. Sci. Technol., 37, 4672-4677, 2003.

Froyd, K. D., Murphy, S. M., Murphy, D. M., deGouw, J. A., Eddingsaas, N. C., and Wennberg, P. O.: Contribution of isoprenederived organosulfates to free tropospheric aerosol mass, P. Natl. Acad. Sci., 108, 21360-21365, doi:10.1073/pnas.1012561107, 2010.

Fu, T., Jacob, D. J., Wittrock, F., Burrows, J. P., Vrekoussis, M., and Henze, D. K.: Global budgets of atmospheric glyoxal, methylglyoxal, and implications for formation of secondary organic aerosol, J. Geophys. Res., 113, D15303, doi:10.1029/2007JD009505, 2008.

Fu, T., Jacob, D. J., and Heald, C. L.: Aqueous-phase reactive uptake of dicarbonyls as a source of organic aerosol over eastern North America, Atmos. Environ., 43, 1814-1822, 2009.

Furukawa, T. and Takahashi, Y.: Oxalate metal complexes in aerosol particles: implications for the hygroscopicity of oxalatecontaining particles, Atmos. Chem. Phys., 11, 4289-4301, doi:10.5194/acp-11-4289-2011, 2011.

Fuzzi, S., Decesari, S., Facchini, M. C., Matta, E., Mircea, M., and Tagliavini, E.: A simplified model of the water soluble organic component of atmospheric aerosol, Geophys. Res. Lett., 28, 4079-4082, 2001.

Fuzzi, S., Facchini, M. C., Decesari, S., Matta, E., and Mircea, M.: Soluble organic compounds in fog and cloud droplets: What have we learned over the past few years?, Atmos. Res., 64, 89-98, 2002.

Galloway, M. M., Chhabra, P. S., Chan, A. W. H., Surratt, J. D., Flagan, R. C., Seinfeld, J. H., and Keutsch, F. N.: Glyoxal uptake on ammonium sulphate seed aerosol: reaction products and reversibility of uptake under dark and irradiated conditions, Atmos. Chem. Phys., 9, 3331-3345, doi:10.5194/acp-9-3331-2009, 2009.

Galloway, M. M., Huisman, A. J., Yee, L. D., Chan, A. W. H., Loza, C. L., Seinfeld, J. H., and Keutsch, F. N.: Yields of oxidized volatile organic compounds during the $\mathrm{OH}$ radical initiated oxidation of isoprene, methyl vinyl ketone, and methacrolein under 
highNO ${ }_{\mathrm{x}}$ conditions, Atmos. Chem. Phys. Discuss., 11, 1069310720, doi:10.5194/acpd-11-10693-2011, 2011a.

Galloway, M. M., Loza, C. L., Chhabra, P. S., Chan, A. W. H., Yee, L. D., Seinfeld, J. H., and Keutsch, F. N.: Analysis of photochemical and dark glyoxal uptake: Implications for SOA formation, Geophys. Res. Lett., 38, L17811, doi:10.1029/2011gl048514, $2011 \mathrm{~b}$.

Gelencser, A., Hoffer, A., Kiss, G., Tombasz, E., Kurdi, R., and Bencze, L.: In-situ formation of Light-Absorbing Organic Matter in Cloud Water, J. Atmos. Chem., 45, 25-33, 2003.

Graber, E. R. and Rudich, Y.: Atmospheric HULIS: How humiclike are they? A comprehensive and critical review, Atmos. Chem. Phys., 6, 729-753, doi:10.5194/acp-6-729-2006, 2006.

Graedel, T. E. and Weschler, C. J.: Chemistry Within Aqueous Atmospheric Aerosols and Raindrops, Rev. Geophys. Space Phys., 19, 505-539, 1981.

Grgic, I., Nieto-Gligorovski, L. I., Net, S., Temime-Roussel, B., Gligorovski, S., and Wortham, H.: Light induced multiphase chemistry of gas-phase ozone on aqueous pyruvic and oxalic acids, Phys. Chem. Chem. Phys., 12, 698-707, 2010.

Griffin, R. J., Nguyen, K., Dabdub, D., and Seinfeld, J. H.: A coupled Hydrophobic-Hydrophilic Model for Predicting Secondary Aerosol Formation, J. Atmos. Chem., 44, 171-190, 2003.

Guzman, M. I., Colussi, A. J., and Hoffmann, M. R.: Photoinduced oligomerization of aqueous pyruvic acid, J. Phys. Chem. A, 110, 3619-3626, 2006.

Hasson, A. S. and Paulson, S. E.: An investigation of the relationship between gas-phase and aerosol borne hydroperoxides in urban air, J. Aerosol Sci., 34, 459-468, 2003.

Hatch, L. E., Creamean, J. M., Ault, A. P., Surratt, J. D., Chan, M. N., Seinfeld, J. H., Edgerton, E. S., Su, Y., and Prather, K. A.: Measurements of Isoprene-Derived Organosulfates in Ambient Aerosols by Aerosol Time-of-Flight Mass Spectrometry - Part 1: Single Particle Atmospheric Observations in Atlanta, Environ. Sci. Technol., 45, 5105-5111, doi:10.1021/es103944a, 2011.

Heald, C. L., Jacob, D. J., Park, R. J., Russell, L. M., Huebert, B. J., Seinfeld, J. H., Liao, H., and Weber, R. J.: A large organic aerosol source in the free troposphere missing from current models, Geophys. Res. Lett., 32, L18809, doi:10.1029/2005GL023831, 2005.

Heald, C. L., Jacob, D. J., Turquety, S., Hudman, R. C., Weber, R. J., Sullivan, A. P., Peltier, R. E., Atlas, E. L., deGouw, J. A., Warneke, C., Holloway, J. S., Newman, J. A., Flocke, F. M., and Seinfeld, J. H.: Concentrations and sources of organic carbon aerosols in the free troposphere over North America, J. Geophys. Res., 111, D23S47, doi:10.1029/2006JD007705, 2006.

Heald, C. L., Coe, H., Jimenez, J. L., Weber, R. J., Bahreini, R., Middlebrook, A. M., Russell, L. M., Jolleys, M., Fu, T.-M., Allan, J. D., Bower, K. N., Capes, G., Crosier, J., Morgan, W. T., Robinson, N. H., Williams, P. I., Cubison, M. J., DeCarlo, P. F., and Dunlea, E. J.: Exploring the vertical profile of atmospheric organic aerosol: comparing 17 aircraft field campaigns with a global model, Atmos. Chem. Phys. Discuss., 11, 25371-25425, doi:10.5194/acpd-11-25371-2011, 2011.

Healy, R. M., Wenger, J. C., Metzger, A., Duplissy, J., Kalberer, M., and Dommen, J.: Gas/particle partitioning of carbonyls in the photooxidation of isoprene and 1,3,5-trimethylbenzene, Atmos. Chem. Phys., 8, 3215-3230, doi:10.5194/acp-8-3215-2008, 2008.
Healy, R. M., Temime, B., Kuprovskyte, K., and Wenger, J. C.: Effect of Relative Humidity on Gas/Particle Partitioning and Aerosol Mass Yield in the Photooxidation of p-Xylene, Environ. Sci. Tech., 43, 1884-1889, doi:10.1021/es802404z, 2009.

Hecobian, A., Zhang, X., Zheng, M., Frank, N., Edgerton, E. S., and Weber, R. J.: Water-Soluble Organic Aerosol material and the light-absorption characteristics of aqueous extracts measured over the Southeastern United States, Atmos. Chem. Phys., 10, 5965-5977, doi:10.5194/acp-10-5965-2010, 2010.

Hennigan, C. J., Sullivan, A. P., Fountoukis, C. I., Nenes, A., Hecobian, A., Vargas, O., Peltier, R. E., Case Hanks, A. T., Huey, L. G., Lefer, B. L., Russell, A. G., and Weber, R. J.: On the volatility and production mechanisms of newly formed nitrate and water soluble organic aerosol in Mexico City, Atmos. Chem. Phys., 8, 3761-3768, doi:10.5194/acp-8-3761-2008, 2008a.

Hennigan, C. J., Bergin, M. H., Dibb, J. E., and Weber, R. J.: Enhanced secondary organic aerosol formation due to water uptake by fine particles, Geophys. Res. Lett, 35, L18801, doi:10.1029/2008GL035046, 2008b.

Hennigan, C. J., Bergin, M. H., and Weber, R. J.: Correlations between water-soluble organic aerosol and water vapor: a synergistic effect from biogenic emissions?, Environ. Sci Technol., 42, 9079-9085, 2008c.

Hennigan, C. J., Bergin, M. H., Russell, A. G., Nenes, A., and Weber, R. J.: Gas/particle partitioning of water-soluble organic aerosol in Atlanta, Atmos. Chem. Phys., 9, 3613-3628, doi:10.5194/acp-9-3613-2009, 2009.

Henze, D. K. and Seinfeld, J. H.: Global secondary organic aerosol from isoprene oxidation, Geophys. Res. Lett., 33, L09812, doi:10.1029/2006GL025976, 2006.

Herckes, P., Lee, T., Trenary, L., Kang, G., Chang, H., and Collett, J. L.: Organic Matter in Central California Radiation Fogs, Environ. Sci. Technol., 36, 4777-4782, doi:10.1021/es025889t, 2002.

Herckes, P., Chang, H., Lee, T., and Collett Jr., J. L.: Air pollution processing by radiation fogs, Water Air Soil Pollut., 181, 65-75, 2007.

Hering, S. V. and Friedlander, S. K.: Origins of Sulfur Size Distributions in the Los Angeles Basin, Atmos. Environ., 16, 2647-2656, 1982.

Herrmann, H.: Kinetics of aqueous phase reactions relevant for atmospheric chemistry, Chem. Rev., 103, 4691-4716, 2003.

Herrmann, H., Ervens, B., Jacobi, H.-W., Wolke, R., Nowacki, P., and Zellner, R.: CAPRAM2.3: A Chemical Aqueous Phase Radical Mechanism for Tropospheric Chemistry, J. Atmos. Chem., 36, 231-284, 2000.

Herrmann, H., Tilgner, A., Barzaghi, P., Majdik, Z., Gligorovski, S., Poulain, L., and Monod, A.: Towards a more detailed description of tropospheric aqueous phase organic chemistry: CAPRAM 3.0, Atmos. Environ, 39, 4351-4363, 2005.

Herrmann, H., Hoffmann, D., Schaefer, T., Bräuer, P., and Tilgner, A.: Tropospheric Aqueous-Phase Free-Radical Chemistry: Radical Sources, Spectra, Reaction Kinetics and Prediction Tools, Chem. Phys. Chem., 11, 3796-3822, doi:10.1002/cphc.201000533, 2010.

Hersey, S. P., Craven, J. S., Schilling, K. A., Metcalf, A. R., Sorooshian, A., Chan, M. N., Flagan, R. C., and Seinfeld, J. H.: The Pasadena Aerosol Characterization Observatory (PACO): chemical and physical analysis of the Western Los Angeles basin 
aerosol, Atmos. Chem. Phys., 11, 7417-7443, doi:10.5194/acp11-7417-2011, 2011.

Hodzic, A., Jimenez, J. L., Madronich, S., Canagaratna, M. R., DeCarlo, P. F., Kleinman, L., and Fast, J.: Modeling organic aerosols in a megacity: potential contribution of semi-volatile and intermediate volatility primary organic compounds to secondary organic aerosol formation, Atmos. Chem. Phys., 10, 5491-5514, doi:10.5194/acp-10-5491-2010, 2010.

Hoffer, A., Kiss, G., Blazsó, M., and Gelencsér, A.: Chemical characterization of humic-like substances (HULIS) formed from a lignin-type precursor in model cloud water, Geophys. Res. Lett., 31, L06115, doi:10.1029/2003g1018962, 2004.

Hoppel, W. A., Frick, G. M., Fitzgerald, J. W., and Larson, R. E.: Marine Boundary layer measurements of new particle formation and the effects nonprecipitating clouds have on aerosol size distribution, J. Geophys. Res., 99, 14443-14459, 1994.

Hoyle, C. R., Boy, M., Donahue, N. M., Fry, J. L., Glasius, M., Guenther, A., Hallar, A. G., Huff Hartz, K., Petters, M. D., Petäjä, T., Rosenoern, T., and Sullivan, A. P.: A review of the anthropogenic influence on biogenic secondary organic aerosol, Atmos. Chem. Phys., 11, 321-343, doi:10.5194/acp-11-321-2011, 2011.

Huang, D., Zhang, X., Chen, Z. M., Zhao, Y., and Shen, X. L.: The kinetics and mechanism of an aqueous phase isoprene reaction with hydroxyl radical, Atmos. Chem. Phys., 11, 7399-7415, doi:10.5194/acp-11-7399-2011, 2011.

Huang, X.-F., Yu, J. Z., He, L.-Y., and Yuan, Z.: Watersoluble organic carbon and oxalate in aerosols at a coastal urban site in China: Size distribution characteristics, sources, and formation mechanisms, J. Geophys. Res., 111, D22212, doi:10.1029/2006jd007408, 2006.

Huang, X. H. H., Ip, H. S. S., and Yu, J. Z.: Secondary organic aerosol formation from ethylene in the urban atmosphere of Hong Kong: A multiphase chemical modeling study, J. Geophys. Res., 116, D03206, doi:10.1029/2010jd014121, 2011.

Igawa, M., Munger, J. W., and Hoffmann, M. R.: Analysis of aldehydes in cloud- and fogwater samples by HPLC with a postcolumn reaction detector, Environ. Sci. Technol, 23, 556-561, 1989.

Ip, H. S. S., Huang, X. H. H., and Yu, J. Z.: Effective Henry's law constants of glyoxal, glyoxylic acid and glycolic acid, Geophys. Res. Lett., 36, L01802, doi:10.1029/2008GL036212, 2009.

Iraci, L. T., Baker, B. M., Tyndall, G. S., and Orlando, J. J.: Measurements of the Henry's Law Coefficients of 2-Methyl-3-buten2-ol, Methacrolein, and Methylvinyl Ketone, J. Atmos. Chem., 33, 321-330, 1999.

Jacobson, M.: Isolating nitrated and aromatic aerosols and nitrated aromatic gases as sources of ultraviolet light absorption, J. Geophys. Res., 104, 3527-3542, 1999.

Jaoui, M., Edney, E. O., Kleindienst, T. E., Lewandowski, M., Offenberg, J. H., Surratt, J. D., and Seinfeld, J. H.: Formation of secondary organic aerosol from irradiated $\alpha$-pinene/toluene/NOx mixtures and the effect of isoprene and sulfur dioxide, J. Geophys. Res., 113, D09303, doi:10.1029/2007jd009426, 2008.

Jathar, S. H., Farina, S. C., Robinson, A. L., and Adams, P. J.: The influence of semi-volatile and reactive primary emissions on the abundance and properties of global organic aerosol, Atmos. Chem. Phys., 11, 7727-7746, doi:10.5194/acp-11-77272011, 2011.

Jimenez, J. L., Canagaratna, M. R., Donahue, N. M., Prevot, A. S.
H., Zhang, Q., Kroll, J. H., DeCarlo, P. F., Allan, J. D., Coe, H., Ng, N. L., Aiken, A. C., Docherty, K. S., Ulbrich, I. M., Grieshop, A. P., Robinson, A. L., Duplissy, J., Smith, J. D., Wilson, K. R., Lanz, V. A., Hueglin, C., Sun, Y. L., Tian, J., Laaksonen, A., Raatikainen, T., Rautiainen, J., Vaattovaara, P., Ehn, M., Kulmala, M., Tomlinson, J. M., Collins, D. R., Cubison, M. J., Dunlea, E. J., Huffman, J. A., Onasch, T. B., Alfarra, M. R., Williams, P. I., Bower, K., Kondo, Y., Schneider, J., Drewnick, F., Borrmann, S., Weimer, S., Demerjian, K., Salcedo, D., Cottrell, L., Griffin, R., Takami, A., Miyoshi, T., Hatakeyama, S., Shimono, A., Sun, J. Y., Zhang, Y. M., Dzepina, K., Kimmel, J. R., Sueper, D., Jayne, J. T., Herndon, S. C., Trimborn, A. M., Williams, L. R., Wood, E. C., Middlebrook, A. M., Kolb, C. E., Baltensperger, U., and Worsnop, D. R.: Evolution of organic aerosols in the atmosphere, Science, 326, 5959, 15251529, doi:10.1126/science.1180353, 2009.

John, W., Wall, S. M., Ondo, J. L., and Winklmayr, W.: Modes in the size distributions of atmospheric inorganic aerosol, Atmos. Environ. A, 24, 2349-2359, doi:10.1016/0960-1686(90)90327-j, 1990.

Jung, J. and Kawamura, K.: Enhanced concentrations of citric acid in spring aerosols collected at the Gosan background site in East Asia, Atmos. Environ., 45, 5266-5272, doi:10.1016/j.atmosenv.2011.06.065, 2011.

Kanakidou, M., Seinfeld, J. H., Pandis, S. N., Barnes, I., Dentener, F. J., Facchini, M. C., Van Dingenen, R., Ervens, B., Nenes, A., Nielsen, C. J., Swietlicki, E., Putaud, J. P., Balkanski, Y., Fuzzi, S., Horth, J., Moortgat, G. K., Winterhalter, R., Myhre, C. E. L., Tsigaridis, K., Vignati, E., Stephanou, E. G., and Wilson, J.: Organic aerosol and global climate modelling: a review, Atmos. Chem. Phys., 5, 1053-1123, doi:10.5194/acp-5-1053-2005, 2005.

Karpel Vel Leitner, N., and Doré, M.: Mecanisme d'action des radicaux $\mathrm{OH}$ sur les acides glycolique, glyoxylique, acetique et oxalique en solution aqueuse: Incidence sur la consammation de peroxyde d'hydrogene dans les systemes $\mathrm{H}_{2} \mathrm{O}_{2} / \mathrm{UV}$ et $\mathrm{O}_{3} / \mathrm{H}_{2} \mathrm{O}_{2}$ (Mechanism of the reaction between hydroxyl radicals and glycolic, glyoxylic, acetic and oxalic acids in aqueous solution: Consequence on hydrogen peroxide consumption in the $\mathrm{H}_{2} \mathrm{O}_{2} / \mathrm{UV}$ and $\mathrm{O}_{3} / \mathrm{H}_{2} \mathrm{O}_{2}$ systems), Water Research, 31, 13831397, 1997.

Kaul, D. S., Gupta, T., Tripathi, S. N., Tare, V., and Collett, J. L.: Secondary Organic Aerosol: A Comparison between Foggy and Nonfoggy Days, Environ. Sci. Technol., 45, 7307-7313, doi:10.1021/es201081d, 2011.

Kawamura, K. and Kaplan, I. R.: Motor Exhaust Emissions as Primary Source for Dicarboxylic Acids in Los Angeles Ambient Air, Environ. Sci. Technol, 21, 105-110, 1987.

Kawamura, K., Kasukabe, H., and Barrie, L. A.: Source and reaction pathways of dicarboxylic acids, ketoacids and dicarbonyls in Arctic aerosols: One year of observations, Atmos. Environ., 30, 1709-1722, 1996a.

Kawamura, K., Steinberg, S., and Kaplan, I. R.: Concentrations of monocarboxylic and dicarboxylic acids and aldehydes in Southern California wet precipitations: comparison of urban and nonurban samples and compositional changes during scavenging, Atmos. Environ., 30, 1035-1052, 1996b.

Kawamura, K. and Sakaguchi, F.: Molecular distributions of water soluble dicarboxylic acids in marine aerosols over the $\mathrm{Pa}$ - 
cific Ocean including tropics, J. Geophys. Res., 104, 3501-3509, 1999.

Kawamura, K., Steinberg, S., and Kaplan, I. R.: Homologous series of $\mathrm{C}_{1}-\mathrm{C}_{10}$ monocarboxylic acids and $\mathrm{C}_{1}-\mathrm{C}_{6}$ carbonyls in Los Angeles air and motor vehicle exhausts, Atmos. Environ., 34, 4175-4191, 2000.

Kawamura, K., Umemoto, N., Mochida, M., Bertram, T., Howell, S., and Huebert, B. J.: Water-soluble dicarboxylic acids in the tropospheric aerosols collected over east Asia and western North Pacific by ACE-Asia C-130 aircraft, J. Geophys. Res., 108, 8639, doi:10.1029/2002JD003256, 2003.

Kawamura, K., Kasukabe, H., and Barrie, L. A.: Secondary formation of water-soluble organic acids and $\alpha$-dicarbonyls and their contributions to total carbon and water-soluble organic carbon: Photochemical aging of organic aerosols in the Arctic spring, J. Geophys. Res., 115, D21306, doi:10.1029/2010jd014299, 2010.

Kerminen, V.-M. and Wexler, A. S.: Growth laws for atmospheric aerosol particles: An examination of the bimodality of the accumulation mode, Atmos. Environ., 29, 3263-3275, doi:10.1016/1352-2310(95)00249-x, 1995.

Kirchstetter, T., Novakov, T., and Hobbs, P. V.: Evidence that the spectral dependence of light absorption by aerosols is affected by organic carbon, J. Geophys. Res., 109, D21208, doi:10.1029/2004JD004999, 2004.

Kristensen, K. and Glasius, M.: Organosulfates and oxidation products from biogenic hydrocarbons in fine aerosols from a forest in North West Europe during spring, Atmos. Environ., 45, 45464556, doi:10.1016/j.atmosenv.2011.05.063, 2011.

Krivacsy, Z., Kiss, G., Ceburnis, D., Jennings, G., Maenhaut, W., Salma, I., and Shooter, D.: Study of water-soluble atmospheric humic matter in urban and marine environments, Atmos. Res., $87,1-12,2008$

Krizner, H. E., DeHaan, D. O., and Kua, K.: Thermodynamics and kinetics of methylglyoxal dimer formation: A computational study, J. Phys Chem. A, 113, 25, 6994-7001, 2009.

Kroll, J. H., Ng, N. L., Murphy, S. M., Flagan, R. C., and Seinfeld, J. H.: Secondary organic aerosol formation from isoprene photooxidation under high $\mathrm{NO}_{\mathrm{x}}$ conditions, Geophys. Res. Lett., 32, L18808, doi:10.1029/2005GL023637, 2005a.

Kroll, J. H., Ng, N. L., Murphy, S. M., Varutbangkul, V., Flagan, R. C., and Seinfeld, J. H.: Chamber studies of secondary organic aerosol growth by reactive uptake of simple carbonyl compounds, J. Geophys. Res., 110, D23207, doi:10.1029/2005JD006004, 2005b.

Kroll, J. H., Donahue, N. M., Jimenez, J. L., Kessler, S. H., Canagaratna, M. R., Wilson, K. R., Altieri, K. E., Mazzoleni, L. R., Wozniak, A. S., Bluhm, H., Mysak, E. R., Smith, J. D., Kolb, C. E., and Worsnop, D. R.: Carbon oxidation state as a metric for describing the chemistry of atmospheric organic aerosol, Nat. Chem., 3, 133-139, 2011.

Kua, J., Hanley, S. W., and DeHaan, D. O.: Thermodynamics and kinetics of glyoxal dimer formation: A computational study, J. Phys. Chem. A, 112, 66-72, 2008.

Kua, J., Krizner, H. E., and De Haan, D. O.: Thermodynamics and Kinetics of Imidazole Formation from Glyoxal, Methylamine, and Formaldehyde: A Computational Study, J. Phys. Chem. A, 115, 1667-1675, doi:10.1021/jp111527x, 2011.

Lambe, A. T., Onasch, T. B., Massoli, P., Croasdale, D. R., Wright, J. P., Ahern, A. T., Williams, L. R., Worsnop, D. R., Brune,
W. H., and Davidovits, P.: Laboratory studies of the chemical composition and cloud condensation nuclei (CCN) activity of secondary organic aerosol (SOA) and oxidized primary organic aerosol (OPOA), Atmos. Chem. Phys., 11, 8913-8928, doi:10.5194/acp-11-8913-2011, 2011.

Lee-Taylor, J., Madronich, S., Aumont, B., Camredon, M., Hodzic, A., Tyndall, G. S., Apel, E., and Zaveri, R. A.: Explicit modeling of organic chemistry and secondary organic aerosol partitioning for Mexico City and its outflow plume, Atmos. Chem. Phys. Discuss., 11, 17013-17070, doi:10.5194/acpd-11-170132011, 2011.

Lee, A. K. Y., Herckes, P., Leaitch, W. R., Macdonald, A. M., and Abbatt, J. P. D.: Aqueous $\mathrm{OH}$ oxidation of ambient organic aerosol and cloud water organics: Formation of highly oxidized products, Geophys. Res. Lett., 38, 11, L11805, doi:10.1029/2011g1047439, 2011.

Lee, S., Murphy, D. M., Thomson, D. S., and Middlebrook, A. M.: Nitrate and oxidized organic ions in single particle mass spectra during the 1999 Atlanta Supersite Project, J. Geophys. Res., 108, 8417, doi:10.1029/2001JD001455, 2003.

Li, Z., Schwier, A. N., Sareen, N., and McNeill, V. F.: Reactive processing of formaldehyde and acetaldehyde in aqueous aerosol mimics: surface tension depression and secondary organic products, Atmos. Chem. Phys. Discuss., 11, 19477-19506, doi:10.5194/acpd-11-19477-2011, 2011.

Liggio, J., Li, S.-M., and McLaren, R.: Heterogeneous reactions of glyoxal on particulate matter: identification of acetals and sulfate esters, Environ. Sci. Technol., 39, 1532-1541, 2005 a.

Liggio, J., Li, S.-M., and McLaren, R.: Reactive uptake of glyoxal by particulate matter, J. Geophys. Res., 110, D10304,doi:10.1029/2004JD005113, 2005b.

Likens, G. E., Edgerton, E. S., and Galloway, J. N.: The composition and deposition of organic carbon in precipitation, Tellus B, 35B, 16-24, doi:10.1111/j.1600-0889.1983.tb00003.x, 1983.

Lim, Y. B., Tan, Y., Perri, M. J., Seitzinger, S. P., and Turpin, B. J.: Aqueous chemistry and its role in secondary organic aerosol (SOA) formation, Atmos. Chem. Phys., 10, 1052110539, doi:10.5194/acp-10-10521-2010, 2010.

Lin, P., Engling, G., and Yu, J. Z.: Humic-like substances in fresh emissions of rice straw burning and in ambient aerosols in the Pearl River Delta Region, China, Atmos. Chem. Phys., 10, 64876500, doi:10.5194/acp-10-6487-2010, 2010a.

Lin, P., Huang, X.-F., He, L.-Y., and Zhen Yu, J.: Abundance and size distribution of HULIS in ambient aerosols at a rural site in South China, J. Aerosol Sci., 41, 74-87, 2010b.

Liu, Y., El Haddad, I., Scarfogliero, M., Nieto-Gligorovski, L., Temime-Roussel, B., Quivet, E., Marchand, N., PicquetVarrault, B., and Monod, A.: In-cloud processes of methacrolein under simulated conditions - Part 1: Aqueous phase photooxidation, Atmos. Chem. Phys., 9, 5093-5105, doi:10.5194/acp-95093-2009, 2009.

Liu, Y., Tritscher, T., Praplan, A. P., DeCarlo, P. F., TemimeRoussel, B., Quivet, E., Marchand, N., Dommen, J., Baltensperger, U., and Monod, A.: Aqueous phase processing of secondary organic aerosols, Atmos. Chem. Phys. Discuss., 11, 21489-21532, doi:10.5194/acpd-11-21489-2011, 2011.

Marcolli, C. and Peter, Th.: Water activity in polyol/water systems: new UNIFAC parameterization, Atmos. Chem. Phys., 5, 15451555, doi:10.5194/acp-5-1545-2005, 2005. 
Maria, S. F., L. M. Russell, M. K. Gilles, and Myeni, S. C. B.: Organic Aerosol Growth Mechanisms and Their Climate Forcing Implications, Science, 306, 1921-1924, 2004.

Martin, S. T., Andreae, M. O., Althausen, D., Artaxo, P., Baars, H., Borrmann, S., Chen, Q., Farmer, D. K., Guenther, A., Gunthe, S. S., Jimenez, J. L., Karl, T., Longo, K., Manzi, A., Müller, T., Pauliquevis, T., Petters, M. D., Prenni, A. J., Pöschl, U., Rizzo, L. V., Schneider, J., Smith, J. N., Swietlicki, E., Tota, J., Wang, J., Wiedensohler, A., and Zorn, S. R.: An overview of the Amazonian Aerosol Characterization Experiment 2008 (AMAZE-08), Atmos. Chem. Phys., 10, 11415-11438, doi:10.5194/acp-1011415-2010, 2010.

Martinelango, P. K., Dasgupta, P. K., and Al-Horr, R. S.: Atmospheric production of oxalic acid/oxalate and nitric acid/nitrate in the Tampa Bay airshed: Parallel pathways, Atmos. Environ., 41, 4258-4269, 2007.

Massoli, P., Lambe, A. T., Ahern, A. T., Williams, L. R., Ehn, M., Mikkilä, J., Canagaratna, M. R., Brune, W. H., Onasch, T. B., Jayne, J. T., Petäjä, T., Kulmala, M., Laaksonen, A., Kolb, C. E., Davidovits, P., and Worsnop, D. R.: Relationship between aerosol oxidation level and hygroscopic properties of laboratory generated secondary organic aerosol (SOA) particles, Geophys. Res. Lett., 37, L24801, doi:10.1029/2010g1045258, 2010.

Mazzoleni, L. R., Ehrmann, B. M., Shen, X., Marshall, A. G., and Collett, J. L.: Water-Soluble Atmospheric Organic Matter in Fog: Exact Masses and Chemical Formula Identification by Ultrahigh-Resolution Fourier Transform Ion Cyclotron Resonance Mass Spectrometry, Environ. Sci. Technol., 44, 36903697, doi:10.1021/es903409k, 2010.

Meng, Z. and Seinfeld, J. H.: On the Source of the Submicrometer Droplet Mode of Urban and Regional Aerosols, Aerosol Sci. Technol., 20, 253-265, 1994.

Meng, Z., Seinfeld, J. H., Saxena, P., and Kim, Y. P.: Contribution of Water to Particulate Mass in the South Coast Air Basin, Aerosol Sci. Technol., 22, 111-123, 1995.

Michaud, V., El Haddad, I., Yao Liu, Sellegri, K., Laj, P., Villani, P., Picard, D., Marchand, N., and Monod, A.: In-cloud processes of methacrolein under simulated conditions - Part 3: Hygroscopic and volatility properties of the formed secondary organic aerosol, Atmos. Chem. Phys., 9, 5119-5130, doi:10.5194/acp-95119-2009, 2009.

Minakata, D., Li, K., Westerhoff, P., and Crittenden, J.: Development of a Group Contribution Method To Predict Aqueous Phase Hydroxyl Radical (HO) Reaction Rate Constants, Environ. Sci Technol., 43, 6220-6227, doi:10.1021/es900956c, 2009.

Minerath, E. C. and Elrod, M. J.: Assessing the Potential for Diol and Hydroxy Sulfate Ester Formation from the Reaction of Epoxides in Tropospheric Aerosols, Environ. Sci Technol., 43, 13861392, doi:10.1021/es8029076, 2009.

Miyazaki, Y., Aggarwal, S. G., Singh, K., Gupta, P. K., and Kawamura, K.: Dicarboxylic acids and water-soluble organic carbon in aerosols in New Delhi, India, in winter: Characteristics and formation processes, J. Geophys. Res., 114, D19206, doi:10.1029/2009jd011790, 2009a.

Miyazaki, Y., Kondo, Y., Shiraiwa, M., Takegawa, N., Miyakawa, T., Han, S., Kita, K., Hu, M., Deng, Z. Q., Zhao, Y., Sugimoto, N., Blake, D. R., and Weber, R. J.: Chemical characterization of water-soluble organic carbon aerosols at a rural site in the Pearl River Delta, China, in the summer of 2006, J. Geophys. Res.,
114, D14208, doi:10.1029/2009jd011736, 2009b.

Moffett, R. C., Qin, X., Rebotier, T., Furutani, H., and Prather, K. A.: Chemically segregated optical and microphysical properties of ambient aerosols measured in a singleparticle mass spectrometer, J. Geophys. Res., 113, D12213, doi:10.1029/2007JD009393, 2008.

Molina, M. J., Ivanov, A. V., Trakhtenberg, S., and Molina, L. T.: Atmospheric evolution of organic aerosol, Geophys. Res. Lett., 31, L22104, doi:10.1029/2004GL020910, 2004.

Monod, A. and Doussin, J. F.: Structure-activity relationship for the estimation of $\mathrm{OH}$-oxidation rate constants of aliphatic organic compounds in the aqueous phase: alkanes, alcohols, organic acids and bases, Atmos. Environ., 42, 7611-7622, doi:10.1016/j.atmosenv.2008.06.005, 2008.

Monod, A., Poulain, L., Grubert, S., Voisin, D., and Wortham, H.: Kinetics of $\mathrm{OH}$-initiated oxidation of oxygenated organic compounds in the aqueous phase: new rate constants, structureactivity relationships and atmospheric implications, Atmos. Environ., 39, 7667-7688, 2005.

Munger, J. W., Tiller, C., and Hoffmann, M. R.: Identification of Hydroxymethanesulfonate in Fog Water, Science, 231, 247-249, 1986.

Munger, J. W., Jacob, D. J., Daube , B. C., Horowitz, L. W., Keene, W. C., and Heikes, B. C.: Formaldehyde, glyoxal and methylglyoxal at a rural mountain site in central Virginia, J. Geophys. Res., 100, 9325-9333, 1995.

Murphy, B. N. and Pandis, S. N.: Simulating the Formation of Semivolatile Primary and Secondary Organic Aerosol in a Regional Chemical Transport Model, Environ. Sci Technol., 43, 4722-4728, doi:10.1021/es803168a, 2009.

Myriokefalitakis, S., Vrekoussis, M., Tsigaridis, K., Wittrock, F., Richter, A., Brhl, C., Volkamer, R., Burrows, J. P., and Kanakidou, M.: The influence of natural and anthropogenic secondary sources on the glyoxal global distribution, Atmos. Chem. Phys., 8, 4965-4981, doi:10.5194/acp-8-4965-2008, 2008.

Myriokefalitakis, S., Tsigaridis, K., Mihalopoulos, N., Sciare, J., Nenes, A., Kawamura, K., Segers, A., and Kanakidou, M.: In-cloud oxalate formation in the global troposphere: a 3-D modeling study, Atmos. Chem. Phys., 11, 5761-5782, doi:10.5194/acp-11-5761-2011, 2011.

Nakayama, T., Matsumi, Y., Sato, K., Imamura, T., Yamazaki, A., and Uchiyama, A.: Laboratory studies on optical properties of secondary organic aerosols generated during the photooxidation of toluene and the ozonolysis of $\alpha$-pinene, J. Geophys. Res., 115, D24204, doi:10.1029/2010jd014387, 2010.

Narukawa, M., Kawamura, K., Anlauf, K. G., and Barrie, L. A.: Fine and coarse modes of dicarboxylic acids in the Arctic aerosols collected during the Polar Sunrise Experiment 1997, J. Geophys. Res., 108, 4575, doi:10.1029/2003JD003646, 2003.

Neusüss, C., Pelzing, M., Plewka, A., and Herrmann, H.: A new analytical approach for size-resolved speciation of organic compounds in atmospheric aerosol particles: Methods and first results, J. Geophys. Res., 105, 4513-4527, doi:10.1029/1999jd901038, 2000.

Ng, N. L., Kroll, J. H., Chan, A. W. H., Chhabra, P. S., Flagan, R. C., and Seinfeld, J. H.: Secondary organic aerosol formation from m-xylene, toluene, and benzene, Atmos. Chem. Phys., 7, 3909-3922, doi:10.5194/acp-7-3909-2007, 2007.

Ng, N. L., Canagaratna, M. R., Zhang, Q., Jimenez, J. L., Tian, 
J., Ulbrich, I. M., Kroll, J. H., Docherty, K. S., Chhabra, P. S., Bahreini, R., Murphy, S. M., Seinfeld, J. H., Hildebrandt, L., Donahue, N. M., DeCarlo, P. F., Lanz, V. A., Prévôt, A. S. H., Dinar, E., Rudich, Y., and Worsnop, D. R.: Organic aerosol components observed in Northern Hemispheric datasets from Aerosol Mass Spectrometry, Atmos. Chem. Phys., 10, 46254641, doi:10.5194/acp-10-4625-2010, 2010.

Nguyen, T. B., Roach, P. J., Laskin, J., Laskin, A., and Nizkorodov, S. A.: Effect of humidity on the composition of isoprene photooxidation secondary organic aerosol, Atmos. Chem. Phys., 11, 6931-6944, doi:10.5194/acp-11-6931-2011, 2011.

Nishino, N., Arey, J., and Atkinson, R.: Formation Yields of Glyoxal and Methylglyoxal from the Gas-Phase $\mathrm{OH}$ RadicalInitiated Reactions of Toluene, Xylenes, and Trimethylbenzenes as a Function of $\mathrm{NO}_{2}$ Concentration, J. Phys Chem. A, 114, 10140-10147, doi:10.1021/jp105112h, 2010.

Noziere, B., Voisin, D., Longfellow, C. A., Friedli, H., Henry, B. E., and Hanson, D. R.: The uptake of methyl vinyl ketone, methacrolein, and 2-methyl-3-butene-2-ol onto sulfuric acid solutions, J. Phys. Chem. A, 110 2387-2395, 2006.

Noziere, B., Dziedzic, P., and Cordova, A.: Products and kinetics of the liquid-phase reaction of glyoxal catalysed by ammonium ions $\left(\mathrm{NH}_{4}^{+}\right)$, J. Phys. Chem. A, 113, 231-237, 2009.

Noziere, B., Dziedzic, P., and Cordova, A.: Inorganic ammonium salts and carbonate salts are efficient catalysts for aldol condensation in atmospheric aerosols, Phys. Chem. Chem. Phys., 12, 3864-3872, 2010a.

Noziere, B., Ekström, S., Alsberg, T., and Holmström, S.: Radical-initiated formation of organosulfates and surfactants in atmospheric aerosols, Geophys. Res. Lett., 37, L05806, doi:10.1029/2009g1041683, 2010b.

Odum, J. R., Hoffmann, T., Bowman, F., Collins, D., Flagan, R. C., and Seinfeld, J. H.: Gas/particle partitioning and secondary organic aerosol yields, Environ. Sci. Technol., 30, 2580-2585, 1996.

Olson, C. N., Galloway, M. M., Yu, G., Hedman, C. J., Lockett, M. R., Yoon, T. P., Stone, E. A., Smith, L. M., and Keutsch, F. N.: Hydroxycarboxylic Acid-Derived Organosulfates: Synthesis, Stability and Quantification in Ambient Aerosol, Environ. Sci. Tech., 45, 6468-6474, 2011.

Olson, T. M. and Hoffmann, M. R.: Hydroxyalkylsulfonate formation: its role as a $\mathrm{S}(\mathrm{IV})$ reservoir in atmospheric water droplets, Atmos. Environ., 23, 985-997, 1989.

Orsini, D. A., Ma, Y., Sullivan, A., Sierau, B., Baumann, K., and Weber, R. J.: Refinements to the particle-into-liquid sampler (PILS) for ground and airborne measurements of water soluble aerosol composition, Atmos. Environ., 37, 1243-1259, doi:10.1016/s1352-2310(02)01015-4, 2003.

Padro, L. T., Tkacik, D., Lathem, T., Hennigan, C. J., Sullivan, A. P., Weber, R. J., Huey, L. G., and Nenes, A.: Investigation of CCN relevant properties and droplet growth kinetics of water-soluble aerosol fraction in Mecixo City, J. Geophys. Res., 115, D09204, doi:09210.01029/02009JD013195, 2010.

Pandis, S. N., Wexler, A. S., and Seinfeld, J. H.: Secondary organic aerosol formation and transport - II. Predicting the ambient secondary organic aerosol size distribution, Atmos. Environ. A, 27, 2403-2416, 1993.

Pang, Y., Turpin, B. J., and Gundel, L. A.: On the Importance of Organic Oxygen for Understanding Organic Aerosol Particles,
Aeros. Sci. Technol., 40, 128-133, 2006.

Pankow, J. F.: An Absorption model of the gas/aerosol partitioning involved in the formation of secondary organic aerosol, Atmos. Environ., 28, 189-193, 1994a.

Pankow, J. F.: An absorption model of the gas/aerosol partitioning of organic compounds in the atmosphere, Atmos. Environ., 28, 185-188, 1994b.

Parikh, H. M., Carlton, A. G., Vizuete, W., and Kamens, R. M.: Modeling secondary organic aerosol using a dynamic partitioning approach incorporating particle aqueous-phase chemistry, Atmos. Environ., 45, 1126-1137, doi:10.1016/j.atmosenv.2010.11.027, 2011.

Peltier, R. E., Hecobian, A. H., Weber, R. J., Stohl, A., Atlas, E. L., Riemer, D. D., Blake, D. R., Apel, E., Campos, T., and Karl, T.: Investigating the sources and atmospheric processing of fine particles from Asia and the Northwestern United States measured during INTEX B, Atmos. Chem. Phys., 8, 1835-1853, doi:10.5194/acp-8-1835-2008, 2008.

Perri, M. J., Seitzinger, S., and Turpin, B. J.: Secondary organic aerosol production from aqueous photooxidation of glycolaldehyde: Laboratory experiments, Atmos. Environ., 43, 1487-1497, 2009.

Perri, M. J., Lim, Y. B., Seitzinger, S. P., and Turpin, B. J.: Organosulfates from glycolaldehyde in aqueous aerosols and clouds: Laboratory studies, Atmos. Environ., 44, 2658-2664, 2010.

Petters, M. D. and Kreidenweis, S. M.: A single parameter representation of hygroscopic growth and cloud condensation nucleus activity, Atmos. Chem. Phys., 7, 1961-1971, doi:10.5194/acp-71961-2007, 2007.

Petters, M. D., Prenni, A. J., Kreidenweis, S. M., DeMott, P. J., Matsunaga, A., Lim, Y. B., and Ziemann, P. J.: Chemical aging and the hydrophobic-hydrophilic conversion of carbonaceous aerosol, Geophys. Res. Lett., 33, L24806, doi:10.1029/2006GL027249, 2006.

Pfrang, C., Shiraiwa, M., and Pöschl, U.: Chemical ageing and transformation of diffusivity in semi-solid multi-component organic aerosol particles, Atmos. Chem. Phys., 11, 7343-7354, doi:10.5194/acp-11-7343-2011, 2011.

Pickle, T., Allen, D. T., and Pratsinis, S. E.: The sources and size distributions of aliphatic and carbonyl carbon in Los Angeles aerosol, Atmos. Environ. A, 24, 2221-2228, doi:10.1016/09601686(90)90253-j, 1990.

Pöschl, U.: Gas-particle interactions of tropospheric aerosols: Kinetic and thermodynamic perspectives of multiphase chemical reactions, amorphous organic substances, and the activation of cloud condensation nuclei, Atmos. Res., 101, 562-573, doi:10.1016/j.atmosres.2010.12.018, 2011.

Reutter, P., Su, H., Trentmann, J., Simmel, M., Rose, D., Gunthe, S. S., Wernli, H., Andreae, M. O., and Pöschl, U.: Aerosoland updraft-limited regimes of cloud droplet formation: influence of particle number, size and hygroscopicity on the activation of cloud condensation nuclei (CCN), Atmos. Chem. Phys., 9, 7067-7080, doi:10.5194/acp-9-7067-2009, 2009.

Riemer, N., West, M., Zaveri, R., and Easter, R.: Estimating black carbon aging time-scales with a particle resolved aerosol model, J. Aerosol Sci., 1, 143-158, 2010.

Rinaldi, M., Decesari, S., Carbone, C., Finessi, E., Fuzzi, S., Ceburnis, D., O’Dowd, C., Sciare, J., Burrows, J., Vrekoussis, M., Er- 
vens, B., Tsigaridis, K., and Facchini, M. C.: Evidence of a natural marine source of oxalic acid and a possible link to glyoxal, J. Geophys. Res., doi:10.1029/2011JD015659, in press, 2011.

Rissman, T., Nenes, A., and Seinfeld, J. H.: Chemical Amplification (or Dampening) of the Twomey effect: Conditions derived from Droplet Activation Theory, J. Atmos. Sci., 61, 919-930, 2004.

Robinson, A. L., Donahue, N. M., Shrivastava, M. K., Weitkamp, E. A., Sage, A. M., Grieshop, A. P., Lane, T. E., Pierce, J. R., and Pandis, S. N.: Rethinking organic aerosols: Semivolatile emissions and photochemical aging, Science, 315, 1259-1262, 2007.

Romakkaniemi, S., Kokkola, H., Smith, J. N., Prisle, N. L., Schwier, A. N., McNeill, V. F., and Laaksonen, A.: Partitioning of semivolatile surface-active compounds between bulk, surface and gas phase, Geophys. Res. Lett., 38, L03807, doi:10.1029/2010g1046147, 2011.

Romero, F. and Oehme, M.: Organosulfates - A new Component of Humic-Like Substances in Atmospheric Aerosols?, J. Atmos. Chem., 52, 283-294, 2005.

Sagebiel, J. C. and Seiber, J. N.: Studies in the occurrence and distribution of wood smoke makrker compounds in foggy atmospheres, Environ. Toxicol. Chem., 12, 813-822, 1993.

Salma, I. and Láng, G. G.: How many carboxyl groups does an average molecule of humic-like substances contain?, Atmos. Chem. Phys., 8, 5997-6002, doi:10.5194/acp-8-5997-2008, 2008.

Salma, I., Ocskay, R., and Lng, G. G.: Properties of atmospheric humic-like substances - water system, Atmos. Chem. Phys., 8, 2243-2254, doi:10.5194/acp-8-2243-2008, 2008.

Sareen, N., Schwier, A. N., Shapiro, E. L., Mitroo, D., and McNeill, V. F.: Secondary organic material formed by methylglyoxal in aqueous aerosol mimics, Atmos. Chem. Phys., 10, 997-1016, doi:10.5194/acp-10-997-2010, 2010.

Schmitt-Kopplin, P., Gelencser, A., Dabek-Zlotorzynska, E., Kiss, G., Hertkorn, N., Harir, M., Hong, Y., and Gebefugi, I.: Analysis of the Unresolved Organic Fraction in Atmospheric Aerosols with Ultrahigh-Resolution Mass Spectrometry and Nuclear Magnetic Resonance Spectroscopy: Organosulfates As Photochemical Smog Constituents, Anal. Chem., 82, 80178026, doi:10.1021/ac101444r, 2010.

Schwier, A. N., Sareen, N., Mitroo, D., Shapiro, E. L., and McNeill, V. F.: Glyoxal-Methylglyoxal Cross-Reactions in Secondary Organic Aerosol Formation, Environ. Sci Technol., 44, 6174-6182, doi:10.1021/es101225q, 2010.

Sciare, J., d'Argouges, O., Sarda-Estève, R., Gaimoz, C., Dolgorouky, C., Bonnaire, N., Favez, O., Bonsang, B., and Gros, V.: Large contribution of water-insoluble secondary organic aerosols in the region of Paris (France) during wintertime, J. Geophys. Res., in press, 2011.

Seinfeld, J. H. and Pandis, S. N.: Atmospheric chemistry and physics, John Wiley \& Sons, New York, 1326 pp., 1998.

Shapiro, E. L., Szprengiel, J., Sareen, N., Jen, C. N., Giordano, M. R., and McNeill, V. F.: Light-absorbing secondary organic material formed by glyoxal in aqueous aerosol mimics, Atmos. Chem. Phys., 9, 2289-2300, doi:10.5194/acp-9-2289-2009, 2009.

Shen, H. and Anastasio, C.: Formation of hydroxyl radical from San Joaquin Valley particles extracted in a cell-free surrogate lung fluid, Atmos. Chem. Phys., 11, 9671-9682, doi:10.5194/acp-119671-2011, 2011.

Shiraiwa, M., Pfrang, C., and Pöschl, U.: Kinetic multi-layer model of aerosol surface and bulk chemistry (KM-SUB): the influ- ence of interfacial transport and bulk diffusion on the oxidation of oleic acid by ozone, Atmos. Chem. Phys., 10, 3673-3691, doi:10.5194/acp-10-3673-2010, 2010.

Shrivastava, M. K., Lipsky, E. M., Stanier, C. O., and Robinson, A. L.: Modeling Semivolatile Organic Aerosol Mass Emissions from Combustion Systems, Environ. Sci. Technol., 40, 26712677, doi:10.1021/es0522231, 2006.

Sievering, H., Boatman, J., Gorman, E., Kim, Y., Anderson, L., Ennis, G., Luria, M., and Pandis, S.: Removal of sulphur from the marine boundary layer by ozone oxidation in sea-salt aerosols, Nature, 360, 571-573, 1992.

Simon, H., Bhave, P. V., Swall, J. L., Frank, N. H., and Malm, W. C.: Determining the spatial and seasonal variability in OM/OC ratios across the US using multiple regression, Atmos. Chem. Phys., 11, 2933-2949, doi:10.5194/acp-11-2933-2011, 2011.

Slowik, J. G., Stroud, C., Bottenheim, J. W., Brickell, P. C., Chang, R. Y.-W., Liggio, J., Makar, P. A., Martin, R. V., Moran, M. D., Shantz, N. C., Sjostedt, S. J., van Donkelaar, A., Vlasenko, A., Wiebe, H. A., Xia, A. G., Zhang, J., Leaitch, W. R., and Abbatt, J. P. D.: Characterization of a large biogenic secondary organic aerosol event from eastern Canadian forests, Atmos. Chem. Phys., 10, 2825-2845, doi:10.5194/acp-10-2825-2010, 2010.

Smith, M. L., Kuwata, M., and Martin, S. T.: Secondary Organic Material Produced by the Dark Ozonolysis of $\alpha$-Pinene Minimally Affects the Deliquescence and Efflorescence of Ammonium Sulfate, Aerosol Sci. Technol., 45, 244-261, 2011.

Sorooshian, A., Brechtel, F. J., Ervens, B., Feingold, G., Varutbangkul, V., Bahreini, R., Murphy, S., Holloway, J. S., Atlas, E. L., Anlauf, K., Buzorius, G., Jonsson, H., Flagan, R. C., and Seinfeld, J. H.: Oxalic acid in clear and cloudy atmospheres: Analysis of data from International Consortium for Atmospheric Research on Transport and Transformation 2004, J. Geophys. Res., 111, D23S45, doi:10.1029/2005JD006880, 2006.

Sorooshian, A., Lu, M.-L., Brechtel, F. J., Jonsson, H., Feingold, G., Flagan, R. C., and Seinfeld, J. H.: On the source of organic acid aerosol layers above clouds, Environ. Sci. Technol., 41, 46474654, 2007.

Sorooshian, A., Murphy, S. M., Hersey, S., Bahreini, R., Jonsson, H., Flagan, R. C., and Seinfeld, J. H.: Constraining the contribution of organic acids and AMS $\mathrm{m} / \mathrm{z}, 44$ to the organic aerosol budget: On the importance of meteorology, aerosol hygroscopicity, and region, Geophys. Res. Lett., 37, L21807, doi:10.1029/2010g1044951, 2010.

Spaulding, R. S., Schade, G. W., Goldstein, A. H., and Charles, M. J.: Characterization of secondary atmospheric photooxidation products: Evidence of biogenic and anthropogenic sources, J. Geophys. Res., 108, 4247, doi:10.1029/2002JD002478, 2003.

Spracklen, D. V., Jimenez, J. L., Carslaw, K. S., Worsnop, D. R., Evans, M. J., Mann, G. W., Zhang, Q., Canagaratna, M. R., Allan, J., Coe, H., McFiggans, G., Rap, A., and Forster, P.: Aerosol mass spectrometer constraint on the global secondary organic aerosol budget, Atmos. Chem. Phys. Discuss., 11, 5699-5755, doi:10.5194/acpd-11-5699-2011, 2011.

Stavrakou, T., Müller, J.-F., De Smedt, I., Van Roozendael, M., Kanakidou, M., Vrekoussis, M., Wittrock, F., Richter, A., and Burrows, J. P.: The continental source of glyoxal estimated by the synergistic use of spaceborne measurements and inverse modelling, Atmos. Chem. Phys., 9, 8431-8446, doi:10.5194/acp-9-8431-2009, 2009. 
Stefan, M. I. and Bolton, J. R.: Reinvestigation of the acetone degradation mechanism in dilute aqueous solution by the $\mathrm{UV} / \mathrm{H}_{2} \mathrm{O}_{2}$ process, Environ. Sci. Technol., 33, 870-873, 1999.

Steinbacher, M., Dommen, J., Ordonez, C., Reimann, S., Grübler, F. C., Staehelin, J., and Prevot, A. S. H.: Volatile Organic Compounds in the Po Basin. Part A: Anthropogenic VOCs, J. Atmos. Chem., 51, 271-291, doi:10.1007/s10874-005-3576-1, 2005.

Stone, E. A., Hedman, C. J., Sheesley, R. J., Shafer, M. M., and Schauer, J. J.: Investigating the chemical nature of humic-like substances (HULIS) in North American atmospheric aerosols by liquid chromatography tandem mass spectrometry, Atmos. Environ., 43, 4205-4213, doi:10.1016/j.atmosenv.2009.05.030, 2009.

Sullivan, A. P. and Weber, R. J.: Chemical characterization of the ambient organic aerosol soluble in water: 1 . Isolation of hydrophobic and hydrophilic fractions with a XAD-8 resin, J. Geophys. Res., 111, D05314, doi:10.1029/2005jd006485, 2006a.

Sullivan, A. P. and Weber, R. J.: Chemical characterization of the ambient organic aerosol soluble in water: 2. Isolation of acid, neutral, and basic fractions by modified sizeexclusion chromatography, J. Geophys. Res., 111, D05315, doi:10.1029/2005jd006486, 2006 b.

Sullivan, R. C. and Prather, K. A.: Investigations of the diurnal cycle and mixing state of oxalic acid in individual particles in Asian aerosol outflow, Environ. Sci Technol., 41, 8062-8069, 2007.

Sun, Y. L., Zhang, Q., Anastasio, C., and Sun, J.: Insights into secondary organic aerosol formed via aqueous-phase reactions of phenolic compounds based on high resolution mass spectrometry, Atmos. Chem. Phys., 10, 4809-4822, doi:10.5194/acp-104809-2010, 2010.

Surratt, J. D., Kroll, J. H., Kleindienst, T. E., Edney, E. O., Claeys, M., Sorooshian, A., Ng, N. L., Offenberg, J. H., Lewandowski, M., Jaoui, M., Flagan, R. C., and Seinfeld, J. H.: Evidence for organosulfates in secondary organic aerosol, Environ. Sci. Technol., 41, 517-527, 2007a.

Surratt, J. D., Lewandowski, M., Offenberg, J. H., Jaoui, M., Kleindienst, T. E., Edney, E. O., and Seinfeld, J. H.: Effect of acidity on secondary organic aerosol formation from isoprene, Environ. Sci Technol., 41, 5363-5369, 2007b.

Tan, Y., Perri, M. J., Seitzinger, S. P., and Turpin, B. J.: Effects of Precursor Concentration and Acidic Sulfate in Aqueous Glyoxal-OH Radical Oxidation and Implications for Secondary Organic Aerosol, Environ. Sci. Technol., 43, 8105-8112, doi:10.1021/es901742f, 2009.

Tan, Y., Carlton, A. G., Seitzinger, S. P., and Turpin, B. J.: SOA from methylglyoxal in clouds and wet aerosols: Measurement and prediction of key products, Atmos. Environ., 44, 5218-5226, 2010.

Tan, Y., Lim, Y. B., Altieri, K. E., Seitzinger, S. P., and Turpin, B. J.: Mechanisms leading to oligomers and SOA through aqueous photooxidation: insights from $\mathrm{OH}$ radical oxidation of acetic acid, Atmos. Chem. Phys. Discuss., 11, 18319-18347, doi:10.5194/acpd-11-18319-2011, 2011.

Tang, Y., Thron, R. P., Mauldin, R. L., and Wine, P. H.: Kinetics and spectroscopy of the $\mathrm{SO}_{4}^{-}$radical in aqueous solution, J. Photochem. and Photobiol. A, 44, 243-258, 1988.

Tilgner, A. and Herrmann, H.: Radical-driven carbonyl-to-acid conversion and acid degradation in tropospheric aqueous systems studied by CAPRAM, Atmos. Environ., 44, 5415-5422, 2010.

Trainic, M., Abo Riziq, A., Lavi, A., Flores, J. M., and Rudich,
Y.: The optical, physical and chemical properties of the products of glyoxal uptake on ammonium sulfate seed aerosols, Atmos. Chem. Phys., 11, 9697-9707, doi:10.5194/acp-11-9697-2011, 2011.

Tsimpidi, A. P., Karydis, V. A., Zavala, M., Lei, W., Molina, L., Ulbrich, I. M., Jimenez, J. L., and Pandis, S. N.: Evaluation of the volatility basis-set approach for the simulation of organic aerosol formation in the Mexico City metropolitan area, Atmos. Chem. Phys., 10, 525-546, doi:10.5194/acp-10-525-2010, 2010.

Turpin, B. J. and Lim, H.: Species contributions to $\mathrm{PM}_{2.5}$ mass concentrations: Revisiting common assumptions for estimating organic mass, Aerosol Sci. Technol., 35, 602-610, 2001.

Turpin, B. J., Saxena, P., and Andrews, E.: Measuring and simulating particulate organics in the atmosphere: problems and prospects, Atmos. Environ., 34, 2983-3013, doi:10.1016/s13522310(99)00501-4, 2000.

Ulbrich, I. M., Canagaratna, M. R., Zhang, Q., Worsnop, D. R., and Jimenez, J. L.: Interpretation of organic components from Positive Matrix Factorization of aerosol mass spectrometric data, Atmos. Chem. Phys., 9, 2891-2918, doi:10.5194/acp-9-2891-2009, 2009.

Virtanen, A., Joutsensaari, J., Koop, T., Kannosto, J., Yli-Pirila, P., Leskinen, J., Makela, J. M., Holopainen, J. K., Pöschl, U., Kulmala, M., Worsnop, D. R., and Laaksonen, A.: An amorphous solid state of biogenic secondary organic aerosol particles, Nature, 467, 824-827, 2010.

Volkamer, R., Jimenez, J. L., SanMartini, F., Dzepina, K., Zhang, Q., Salcedo, D., Molina, L. T., Worsnop, D. R., and Molina, M. J.: Secondary organic aerosol formation from anthropogenic air pollution: Rapid and higher than expected, Geophys. Res. Lett., 33, L17811, doi:10.1029/2006GL026899, 2006.

Volkamer, R., SanMartini, F., Molina, L. T., Salcedo, D., Jimenez, J., and Molina, M. J.: A missing sink for gas-phase glyoxal in Mexiko City: Formation of secondary organic aerosol, Geophys. Res. Lett., 34, L19807, doi:10.1029/2007GL030752, 2007.

Volkamer, R., Ziemann, P. J., and Molina, M. J.: Secondary Organic Aerosol Formation from Acetylene $\left(\mathrm{C}_{2} \mathrm{H}_{2}\right)$ : seed effect on SOA yields due to organic photochemistry in the aerosol aqueous phase, Atmos. Chem. Phys., 9, 1907-1928, doi:10.5194/acp9-1907-2009, 2009.

von Hessberg, C., von Hessberg, P., Pöschl, U., Bilde, M., Nielsen, O. J., and Moortgat, G. K.: Temperature and humidity dependence of secondary organic aerosol yield from the ozonolysis of $\beta$-pinene, Atmos. Chem. Phys., 9, 3583-3599, doi:10.5194/acp9-3583-2009, 2009.

Wang, J., Jacob, D. J., and Martin, S. T.: Sensitivity of sulfate direct climate forcing to the hysteresis of particle phase transitions, $\mathrm{J}$ Geophys. Res., 113, D11207, doi:10.1029/2007jd009368, 2008.

Wang, J., Doussin, J.-F., Perrier, S., Perraudin, E., Katrib, Y., Pangui, E., and Picquet-Varrault, B.: Design of a new multi-phase experimental simulation chamber for atmospheric photosmog, aerosol and cloud chemistry research, Atmos. Meas. Tech. Discuss., 4, 315-384, doi:10.5194/amtd-4-315-2011, 2011.

Wang, L., Khalizov, A. F., Zheng, J., Xu, W., Ma, Y., Lal, V., and Zhang, R.: Atmospheric nanoparticles formed from heterogeneous reactions of organics, Nature Geosci., 3, 238-242, 2010.

Wang, L., Xu, W., Khalizov, A., Zheng, J., Qiu, C., and Zhang, R.: Laboratory Investigation on the Role of Organics in Atmospheric Nanoparticle Growth, J. Phys. Chem. A, 115, 8940 
8947, doi:10.1021/jp1121855, 2011.

Wang, Y., Arellanes, C., Curtis, D. B., and Paulson, S. E.: Probing the Source of Hydrogen Peroxide Associated with Coarse Mode Aerosol Particles in Southern California, Environ. Sci. Technol., 44, 4070-4075, doi:10.1021/es100593k, 2010.

Warneck, P.: In-cloud chemistry opens pathway to the formation of oxalic acid in the marine atmosphere, Atmos. Environ., 37, 2423-2427, 2003.

Weber, R. J., Sullivan, A. P., Peltier, R. E., Russell, A., Yan, B., Zheng, M., DeGouw, J., Warneke, C., Brock, C., Holloway, J. S., Atlas, E. L., and Edgerton, E.: A study of secondary organic aerosol formation in the anthropogenicinfluenced southeastern United States, J. Geophys. Res., 112, D13302, doi:10.1029/2007JD008408, 2007.

Whiteaker, J. and Prather, K. A.: Hydroxymethanesulfonate as a tracer for fog processing of individual aerosol particles, Atmos. Environ., 37, 1033-1043, 2003.

Yao, X., Fang, M., and Chan, C. K.: Size distributions and formation of dicarboxylic acids in atmospheric particles, Atmos. Environ., 36, 2099-2107, 2002.

Yao, X., Lau, A. P. S., Fang, M., Chan, C. K., and Hu, M.: Size distribution and formation of ionic species in atmospheric particulate pollutants in Beijing, China: 2. dicarboxylic acids, Atmos. Environ., 37, 3001-3007, 2003.

Yasmeen, F., Sauret, N., Gal, J.-F., Maria, P.-C., Massi, L., Maenhaut, W., and Claeys, M.: Characterization of oligomers from methylglyoxal under dark conditions: a pathway to produce secondary organic aerosol through cloud processing during nighttime, Atmos. Chem. Phys., 10, 3803-3812, doi:10.5194/acp-103803-2010, 2010.

Yu, G., Bayer, A. R., Galloway, M. M., Korshavn, K. J., Fry, C. G., and Keutsch, F. N.: Glyoxal in Aqueous Ammonium Sulfate Solutions: Products, Kinetics and Hydration Effects, Environ. Sci. Tech., 45, 6336-6342, doi:10.1021/es200989n, 2011.

Yu, J. Z., Huang, X.-F., Xu, J., and Hu, M.: When Aerosol sulfate goes up, so does Oxalate: Implication for the Formation Mechanisms of Oxalate, Environ. Sci. Technol., 39, 128-133, 2005.
Zellner, R., Exner, M., and Herrmann, H.: Absolute OH Quantum Yields in the Laser Photolysis of Nitrate, Nitrite and Dissolved $\mathrm{H}_{2} \mathrm{O}_{2}$ at 308 and $351 \mathrm{~nm}$ in the Temperature Range of 278-353 K, J. Atmos. Chem., 10, 411-425, 1990.

Zhang, H. and Ying, Q.: Secondary organic aerosol formation and source apportionment in Southeast Texas, Atmos. Environ., 45, 3217-3227, doi:10.1016/j.atmosenv.2011.03.046, 2011.

Zhang, H., Surratt, J. D., Lin, Y. H., Bapat, J., and Kamens, R. M.: Effect of relative humidity on SOA formation from isoprene/NO photooxidation: enhancement of 2-methylglyceric acid and its corresponding oligoesters under dry conditions, Atmos. Chem. Phys., 11, 6411-6424, doi:10.5194/acp-11-6411-2011, 2011.

Zhang, X., Chen, Z. M., and Zhao, Y.: Laboratory simulation for the aqueous $\mathrm{OH}$-oxidation of methyl vinyl ketone and methacrolein: significance to the in-cloud SOA production, Atmos. Chem. Phys., 10, 9551-9561, doi:10.5194/acp-10-9551-2010, 2010.

Zhang, X., Liu, J., Lin, Y., Surratt, J. D., Hayes, P. L., Jimenez, J. L., Parker, E. T., and Weber, R. J.: Evidence for different formation pathways of soluble organic aerosols in two urban atmospheres with contrasting emissions, in preparation, 2011.

Ziemann, P. J.: Atmospheric Chemistry: Phase matters for aerosols, Nature, 467, 797-798, 2010.

Zuend, A., Marcolli, C., Luo, B. P., and Peter, T.: A thermodynamic model of mixed organic-inorganic aerosols to predict activity coefficients, Atmos. Chem. Phys., 8, 4559-4593, doi:10.5194/acp8-4559-2008, 2008.

Zuend, A., Marcolli, C., Booth, A. M., Lienhard, D. M., Soonsin, V., Krieger, U. K., Topping, D. O., McFiggans, G., Peter, T., and Seinfeld, J. H.: New and extended parameterization of the thermodynamic model AIOMFAC: calculation of activity coefficients for organic-inorganic mixtures containing carboxyl, hydroxyl, carbonyl, ether, ester, alkenyl, alkyl, and aromatic functional groups, Atmos. Chem. Phys., 11, 9155-9206, doi:10.5194/acp-11-9155-2011, 2011. 